\title{
Theoretical Isotope Fractionation of Cadmium during Complexation with Organic Ligands
}

(3)

(1)

(1)

\author{
Yang Zhao a, Yongbing Li ${ }^{\mathrm{b}, *}$, Matthias Wiggenhauser ${ }^{\mathrm{c}, \mathrm{d}, *}$, Junli Yang ${ }^{\mathrm{a}}$, \\ Géraldine Sarret $^{\mathrm{c}}$, Qi Cheng ${ }^{\mathrm{a}}$, Jianming Liu ${ }^{\mathrm{a}}$,, Yaolin Shi ${ }^{\mathrm{b}}$
}

${ }^{a}$ College of Earth and Planetary Sciences, University of Chinese Academy of Sciences, Beijing 100049, China

${ }^{b}$ Key Laboratory of Computational Geodynamics, Chinese Academy of Sciences, University of Chinese Academy of

Sciences, Beijing 100049, China

'ISTerre, Univ. Grenoble Alpes, Univ. Savoie Mont Blanc, CNRS, IRD, IFSTTAR, Grenoble, France

${ }^{d}$ Institute of Agricultural Sciences, ETH Zurich, Eschikon 33, CH-8315 Lindau, Switzerland

${ }^{e}$ Key Laboratory of Mineral Resources, Institute of Geology and Geophysics, Chinese Academy of Sciences,

Beijing 100029, China

*Corresponding authors:

Yongbing Li

No. 19A, Yuquan Road, Shijingshan District, Beijing 100049, PR China.

Tel.: +86 1088256476 .

E-mail address: yongbingli@ucas.ac.cn (Y. Li)

Matthias Wiggenhauser

Institute of Agricultural Sciences, ETH Zurich, Eschikon 33, CH-8315 Lindau, Switzerland

Tel.: +41523549216

E-mail address: matthias.wiggenhauser@usys.ethz.ch (M. W) 
Abstract: Cadmium (Cd) isotopes are an important tool to better understand both inorganic and organic geochemistry of $\mathrm{Cd}$, and organic ligands play a key role to control the toxicity and mobility of $\mathrm{Cd}$ in living organisms and also in terrestrial and aquatic environments. Knowledge of the equilibrium isotope fractionation of $\mathrm{Cd}$ with organic ligands is crucial to further advance $\mathrm{Cd}$ isotope source and process tracing in the field of biogeochemistry. In this study, we calculated reduced partition function ratios $\left(10^{3} \ln \beta\right)$ of $\mathrm{Cd}$ isotopes in various organic $\mathrm{Cd}$ complexes by density functional theory. The calculation results show that the $10^{3} \ln \beta$ of ${ }^{114} \mathrm{Cd} /{ }^{110} \mathrm{Cd}$ for these complexes are decreased in the order of $\mathrm{Cd}(\mathrm{Hcit})\left(\mathrm{H}_{2} \text { cit }\right)^{-}>\mathrm{Cd}(\mathrm{cit})\left(\mathrm{H}_{2} \mathrm{O}\right)_{3}{ }^{-}>$ $\mathrm{CdH}(\mathrm{cit})\left(\mathrm{H}_{2} \mathrm{O}\right)_{4}>\mathrm{CdEDTA}>\mathrm{Cd}(\text { his })_{2} \mathrm{H}_{2} \mathrm{O}>\mathrm{Cd}(\mathrm{cit})_{2}{ }^{4-} \approx \mathrm{Cd}\left(\mathrm{H}_{2} \mathrm{O}\right)_{6}{ }^{2+}>\mathrm{Cd}\left(\mathrm{H}_{2} \mathrm{O}\right)_{4}{ }^{2+}>$ $\mathrm{Cd}(\mathrm{cys})\left(\mathrm{H}_{2} \mathrm{O}\right)_{3}{ }^{2+}>\mathrm{Cd}(\mathrm{GS})_{2}\left(\mathrm{H}_{2} \mathrm{O}\right)_{2} 2^{2-}>\mathrm{Cd}(\mathrm{DMPS})\left(\mathrm{H}_{2} \mathrm{O}\right)_{2}{ }^{-}>\mathrm{Cd}(\mathrm{DMPS})_{2}{ }^{4-}$ at 0 $100^{\circ} \mathrm{C}$, and heavy $\mathrm{Cd}$ isotopes preferably bind to oxygen and nitrogen donor atoms while light $\mathrm{Cd}$ isotopes bind to sulfur donor atoms of organic ligands. Thus, the previously observed immobilization of light $\mathrm{Cd}$ isotopes in living organisms could be related to $\mathrm{Cd}$ detoxification processes with sulfur. The predicted equilibrium isotope fractionation will strengthen $\mathrm{Cd}$ isotopes as a process tracing tool in these systems and will improve the understanding of $\mathrm{Cd}$ isotope cycling in aquatic and terrestrial systems.

Keywords: Cd isotope; Organic complexes; Equilibrium isotope fractionation; O/N/S donor; Destiny functional theory; Isotope biogeochemistry 


\section{Introduction}

Cadmium $(\mathrm{Cd})$ is a non-essential element for most living organisms (Sigel et al., 2013). It is ubiquitous in terrestrial and aquatic environments where it can occur naturally or through anthropogenic activities (Kabata-Pendias, 2011; Liu et al., 2017). Being very mobile, it is readily taken up by living organisms (Khan et al., 2014; Thévenod et al., 2019), where it can impair the organisms itself (Sigel et al., 2013) and/or it can be further transported along the food chain and accumulated in animals and humans (Fransson et al., 2014; Satarug et al., 2010). Thus, the understanding of processes that control the fate of $\mathrm{Cd}$ in the terrestrial and aquatic environments are crucial.

Isotope geochemistry has been increasingly applied in the past years for tracing anthropogenic Cd pollution (Cloquet et al., 2006; Salmanzadeh et al., 2017; Imseng et al., 2018; Yang et al., 2019), tracing the source of ore-forming fluids (Zhu et al., 2016), to advance the understanding of the past and present marine biogeochemical cycling of Cd (Lambelet et al., 2013; Zhang et al., 2018; Sieber et al., 2019), as well as to trace processes that control the $\mathrm{Cd}$ homeostasis in unicell organisms (Horner et al., 2013; Moore et al., 2020) and distinct types of plants such as grasses (Wiggenhauser et al., 2016; Imseng et al., 2018; Wiggenhauser et al., 2021; Zhang et al., 2021), cacao (Barraza et al., 2019; Moore et al., 2020), and Cd accumulating plants (Wei et al., 2016; Zhou et al., 2020). Cd has eight stable isotopes which atomic masses range from 106-116, their ratios can vary significantly in the environment 
(Hoefs, 2015). Cd isotope fractionation in terrestrial and aquatic systems is generated by multiple processes such as sorption to reactive surfaces (Wasylenki et al., 2014), precipitation of Cd into minerals (e.g., calcite, Horner et al., 2011; Guinoiseau et al., 2018; sphalerite, Zhu et al., 2013), membrane transport (Wei et al., 2016), weathering (Zhang et al., 2016; Zhu et al., 2018), binding to inorganic materials (Wasylenki et al., 2014; Yang et al., 2015; Guinoiseau et al., 2018), and complexation with organic ligands as shown for other metals (Morgan et al., 2010; Ryan et al., 2014; Marković et al., 2017). Once isotope fractionation factors are defined for these processes, $\mathrm{Cd}$ isotopes can provide novel information about major biogeochemical processes that control the mobility of $\mathrm{Cd}$ in complex terrestrial and aquatic systems. For $\mathrm{Cd}$, binding to organic ligands plays a crucial role in detoxifying, sequestrating and separating toxic Cd from essential nutrients in living organisms (Wang and Wang, 2009; Cao et al., 2018; Le Croizier et al., 2019). Recent studies showed that Cd isotopes are strongly fractionated in living organisms which has been attributed to processes such as membrane transport (Moore et al., 2020) and Cd binding to organic ligands (Wiggenhauser et al., 2016, 2018, 2021). For the latter, it was hypothesized that Cd binding to reduced sulfur groups (R-SH, thiols) in the bacteria E.coli to detoxify $\mathrm{Cd}$ resulted in an enrichment of light isotope in membranes (Horner et al., 2013). Furthermore, cereals strongly retained light $\mathrm{Cd}$ isotopes in roots which lead to an enrichment of heavy isotopes in shoots and grains (Wiggenhauser et al., 2016; Imseng et al., 2019; Wiggenhauser et al., 2021; Zhang et al., 2021). The immobilization of light isotopes was ascribed to binding of $\mathrm{Cd}$ to thiols to detoxify and sequestrate $\mathrm{Cd}$ in 
roots and shoot parts and to avoid accumulation of Cd in grains (Wiggenhauser et al., 2016). Together, studies in living organisms proposed that sulfur (S) involved detoxification and immobilization processes of $\mathrm{Cd}$ could be a major driver of $\mathrm{Cd}$ isotope fractionation. However, no isotope fractionation factor for $\mathrm{Cd}$ binding to distinct organic ligands exist yet, which makes it difficult to interpret $\mathrm{Cd}$ isotope fractionation in complex biological systems.

During the past few years, calculating isotope fractionation for distinct metal complexes has significantly improved metal isotope process tracing applications in complex biogeochemical systems (Fujii and Albarède, 2012; Moynier et al., 2013; Fujii et al., 2014; Wiederhold, 2015; Albarede et al., 2016; Moynier and Fujii, 2017). For inorganic $\mathrm{Cd}$ complexes, theoretical calculations predicted that $\mathrm{Cd}$ hydroxides and $\mathrm{Cd}$ nitrates are isotopically heavier compared to hydrated $\mathrm{Cd}$ while hydrated $\mathrm{Cd}$ is heavier than Cd chlorides and hydrosulfide (Yang et al., 2015). Guinoiseau et al. (2018) recently verified these in a Cd sulfide precipitation experiment which revealed that $\mathrm{Cd}$ light isotope was enriched in sulfide and that the enrichment of light isotope decreased with increasing chloride concentration in solution. For organic ligands, either experimental or theoretical $\mathrm{Cd}$ isotope fractionation data of $\mathrm{Cd}$ organic complexes has not been studied. Such $\mathrm{Cd}$ isotope fractionation data would be particularly useful to improve $\mathrm{Cd}$ isotope process in tracing complex biogeochemical systems where organic ligands play a crucial role on the fate of $\mathrm{Cd}$ in the environment. Here, we aimed to strengthen $\mathrm{Cd}$ isotope process tracing approaches by applying density functional theory (DFT) to calculate $\mathrm{Cd}$ hydrated complexes 
$117 \mathrm{Cd}\left(\mathrm{H}_{2} \mathrm{O}\right)_{4}{ }^{2+}$ and $\mathrm{Cd}\left(\mathrm{H}_{2} \mathrm{O}\right)_{6}{ }^{2+} ;$ Cd-citrate complexes $\mathrm{Cd}(\mathrm{cit})_{2}{ }^{4-}, \mathrm{Cd}(\mathrm{Hcit})\left(\mathrm{H}_{2} \mathrm{cit}\right)^{-}$, $118 \mathrm{CdH}($ cit $)\left(\mathrm{H}_{2} \mathrm{O}\right)_{4}$ and $\mathrm{Cd}(\mathrm{cit})\left(\mathrm{H}_{2} \mathrm{O}\right)_{3}{ }^{-}$; CdEDTA; Cd-histidine Cd(his $)_{2} \mathrm{H}_{2} \mathrm{O}$; Cd-DMPS 119 complexes Cd(DMPS $)_{2}{ }^{4-}$ and $\mathrm{Cd}(\mathrm{DMPS})\left(\mathrm{H}_{2} \mathrm{O}\right)_{2}{ }^{-} ; \mathrm{Cd}$-cysteine $\mathrm{Cd}(\mathrm{cys})\left(\mathrm{H}_{2} \mathrm{O}\right)_{3}{ }^{2+} ; \mathrm{Cd}-$ 120 glutathione complex $\mathrm{Cd}(\mathrm{GS})_{2}\left(\mathrm{H}_{2} \mathrm{O}\right)_{2}{ }^{2-}$. The obtained results were discussed regarding 121 its implications for past and future $\mathrm{Cd}$ isotope processes tracing approaches.

\section{Theory and methods}

\subsection{Cd organic complexes}

Oxygen $(\mathrm{O})$, nitrogen $(\mathrm{N})$, and sulfur $(\mathrm{S})$ are abundant elements that essential for all living organisms. In organic ligands, they serve as donor atoms to bind metals such as Cd as part of organic complexes such as citrate (cit) (McLean et al., 2013; Panfili et al., 2009; Zorrig et al., 2010), histidine (his) (Wierzbicka et al., 2007; Gunawardana et compounds for strong chelating complexes. EDTA represents chelators with $\mathrm{O}$ and $\mathrm{N}$ 
Puschenreiter et al., 2017) and DMPS represents strong chelators with S donors such as phytochelatin (Marentes and Rauser, 2007; Pal et al., 2019).

\subsection{Calculations}

Equilibrium isotope exchange reaction between two metal complexes can be represented by:

$$
A Y+B Y^{*}=A Y^{*}+B Y
$$

where $Y$ denotes one element that is represented by light $(Y)$ and heavy isotopes $\left(Y^{*}\right)$. $A$ and $B$ represent two different ligands. Ligands and isotopes of $Y$ form the chemical complexes $A Y$ and $B Y$. The isotope fractionation factor $\alpha$ between the complexes $A Y$ and $B Y$ is defined as:

$$
\alpha_{\mathrm{AY}-\mathrm{BY}}=\mathrm{K}_{\mathrm{eq}}=\frac{\beta_{\mathrm{AY}}}{\beta_{\mathrm{BY}}}
$$

the isotope fractionation factor is expressed in permill [\%o]:

$$
10^{3} \ln \alpha_{\mathrm{AY}-\mathrm{BY}}=10^{3} \ln \beta_{\mathrm{AY}}-10^{3} \ln \beta_{\mathrm{BY}}
$$

In these equations, $K$ is the equilibrium constant, which is equal to the $\alpha$ of the isotope exchange reaction of chemical complexes $(A Y, B Y)$ that exchange the same element $(Y) . \beta$ is the reduced partition function ratio (RPFR). Bigeleisen and Mayer (1947) and Urey (1947) suggested that equilibrium mass-dependent isotope fractionation factors results from the molecular vibrational frequencies. $\beta$ can be calculated as:

$$
\beta_{114-110}=\prod_{i}{ }_{i 110} U_{i} U_{i} \frac{e^{-114} U_{i} / 2}{e^{-110} U_{i} / 2} \frac{1-e^{-110} U_{i}}{1-e^{-114} U_{i}}
$$


$U_{i}$ and $v_{i}$ are defined as:

162

$$
U_{i}=h v_{i} / k T
$$

Here, $h, k$, and $T$ refer to the Planck's constant, Boltzmann constant and absolute temperature, respectively. $v_{i}$ is the harmonic vibrational frequency of the $i$ th vibrational mode in $s^{-1}$. The number of vibrational modes for non-linear molecules is $3 n-6$ ( $n$ is the number of atoms in the molecule), $3 n-5$ for linear molecules.

In this study ${ }^{114} \mathrm{Cd} /{ }^{110} \mathrm{Cd}$ isotope ratios were chosen to study the $\mathrm{Cd}$ isotope fractionation of $\mathrm{Cd}$ partitioning into different chemical complexes. The ${ }^{114} \mathrm{Cd} /{ }^{110} \mathrm{Cd}$ is a widely used isotope ratio in experimental (Rehkämper et al., 2011; Horner et al., 2013; Pallavicini et al., 2014; Chrastný et al., 2015; Wei et al., 2016; Li et al., 2018) and theoretical studies (Yang et al., 2015). Gaussian 09 (Dennington et al., 2009; Frisch et al., 2009) was used to calculate the geometries optimization and vibrational frequencies of $\mathrm{Cd}$ species using Becke-style 3-parameter (B3) density functional theory with the Lee-Yang-Parr (LYP) correlation functional (Lee et al., 1988; Becke, 1993a, b). In this study, the mixed basis sets were used, for H, C, N, O, and S, the allelectron basis set 6-311+G(d, p) was used (Clark et al., 1983; Francl et al., 1982; Krishnan et al., 1980; McLean and Chandler, 1980; Spitznagel et al., 1987); for Cd, an effective-core potential (ECP) basis set LanL2DZ was chosen (Hay and Wadt, 1985). The "ultrafine" numerical integration grid was used and the molecular geometries were optimized without any forced symmetry for all complexes. The setting of exchange correlation functionals may have effect on the calculated vibrational frequencies, and four exchange correlation functionals B3LYP, BVP86, 
183

184

185

186

187

188

189

190

191

192

193

194

195

196

197

198

199

200

201

202

203

204

B3PW91 and PBEPBE were tested. For Cd(Hcit)( $\left.\mathrm{H}_{2} \mathrm{cit}\right)^{-}$, the mean square errors of the calculated vibrational frequencies of the four exchange correlation functionals are 366.90, 874.94, 1084.19 and 7440.05 respectively (Table S1), the calculated frequencies by B3LYP are more consistent with the experimental results and the B3LYP functional was chosen to estimate the isotope fractionation of $\mathrm{Cd}$ complexes in this study.

\section{Results and discussion}

\subsection{Optimized molecular geometries}

The optimized geometries of the organic Cd complexes are shown in Fig. 1. For comparison, Table 1 lists the optimized bond lengths calculated by this study, and previously published theoretical and experimental data. Donor atoms, optimized coordinated bond lengths $(\AA)$ and mean bond lengths $(\AA)$ are shown in Table S3 (Supplementary material). The optimized Cd-O distances of $\mathrm{Cd}\left(\mathrm{H}_{2} \mathrm{O}\right)_{4}{ }^{2+}$ and $\mathrm{Cd}\left(\mathrm{H}_{2} \mathrm{O}\right){ }_{6}{ }^{2+}$ (Fig. 1a, b) by using the basis set $6-311+\mathrm{G}(\mathrm{d}, \mathrm{p})$ are consistent with those by using the basis set 6-31+G(d, p) (Yang et al., 2015).

For Cd-citrate complexes: $\mathrm{Cd}(\mathrm{cit})_{2}{ }^{4-}, \mathrm{Cd}(\mathrm{Hcit})\left(\mathrm{H}_{2} \mathrm{cit}\right)^{-}, \mathrm{CdH}(\mathrm{cit})\left(\mathrm{H}_{2} \mathrm{O}\right)_{4}$ and $\mathrm{Cd}(\mathrm{cit})\left(\mathrm{H}_{2} \mathrm{O}\right)_{3}{ }_{3}^{-}$, the deprotonated carboxyl groups in $\mathrm{Cit}^{3-}$ are always coordinated to the central $\mathrm{Cd}^{2+}$ (Bertoli et al., 2015). The $\mathrm{d} 10$ electron configuration of $\mathrm{Cd}^{2+}$ favors sixfold coordination and forms octahedral geometry (Siddiqui et al., 2011), while in 
205

206

207

208

209

210

211

212

213

214

215

216

217

218

219

220

221

222

223

224

225

226

less bulky ligands, $\mathrm{Cd}^{2+}$ tends to form tetrahedral coordination complexes (Ramalho and Figueroa-Villar, 2002; Bertoli et al., 2015). Cd(cit) $2^{4-}$ (Fig. 1c) and $\mathrm{Cd}(\mathrm{Hcit})\left(\mathrm{H}_{2} \text { cit) }\right)^{-}$(Fig. 1d) with fourfold coordination complexes, are adducts of two citrate molecules and have several isomers in solution (Bertoli et al., 2015). They differ in their protonation and each of the two citrate molecules provided two carboxylate oxygen atoms to coordinate to $\mathrm{Cd}^{2+}$. The coordinated bond lengths of $\mathrm{Cd}(\mathrm{cit})_{2}{ }^{4-}$ and $\mathrm{Cd}(\mathrm{Hcit})\left(\mathrm{H}_{2} \mathrm{cit}\right)^{-}$were $2.21,2.22 \AA$ and $2.14-2.38 \AA$ respectively. The $\mathrm{Cd}$ atoms in $\mathrm{CdH}(\mathrm{cit})\left(\mathrm{H}_{2} \mathrm{O}\right)_{4}$ (Fig. 1e) and $\mathrm{Cd}(\mathrm{cit})\left(\mathrm{H}_{2} \mathrm{O}\right)_{3}{ }^{-}$(Fig. 1f) were sixfold coordinated, their bond lengths were 2.24-2.40 $\AA$ and 2.24-2.43 $\AA$, respectively.

CdEDTA (Fig. 1g) is sixfold coordinated, and EDTA provides two $\mathrm{N}$ and four $\mathrm{O}$ donor atoms for $\mathrm{Cd}^{2+}$. The stronger binding of $\mathrm{Cd}^{2+}$ to $\mathrm{N}$ than to $\mathrm{O}$, and the electrostatic attraction induced by the carboxylate result in a high stability for CdEDTA (Kovács et al., 2010; Karak et al., 2016). The calculated Cd-O and Cd-N distances (Cd-O: 2.26, 2.36; Cd-N: 2.48, Table 1b) in this study were close to those calculated by Kovács et al. (2010). Cd-histidine (Cd(his) ${ }_{2} \mathrm{H}_{2} \mathrm{O}$, Fig. 1h) is also sixfold coordinated and contains an imidazole ring, carboxyl and amino groups that provide four $\mathrm{N}$ and two $\mathrm{O}$ donor atoms for $\mathrm{Cd}^{2+}$ (Colaneri et al., 2013). The calculated distances were 2.26 $\AA$ for Cd-O 2.41-2.48 $\AA$ for Cd-N (Table 1b).

The ligand DMPS contains two thiolate groups and one sulfonate group, and the thiol groups of the DMPS chelate $\mathrm{Cd}^{2+}$ in fourfold coordination (Zeini Jahromi et al., 2014, Fig. 1i and 1j). For 1:1 Cd-DMPS complexes, the calculated average distance of Cd to its $\mathrm{S}$ donor atoms was $2.48 \AA$. For 1:2 Cd-DMPS complexes, the average bond 
distance to four $\mathrm{S}$ donor atoms was $2.69 \AA$. The calculated bond lengths were consistent with the previously published values (Table 1b) (Zeini Jahromi et al., 2014).

For $\mathrm{Cd}($ cys $)\left(\mathrm{H}_{2} \mathrm{O}\right)_{3}{ }^{2+}$ (Fig. 1k), the thiol group of cysteine tends to bind the metal ion by $\mathrm{S}$ donor atoms when cysteine is present in excess (Jalilehvand et al., 2009; Fujii et al., 2014). In our study, Cd was bound to three water molecules and one thiol group of cysteine, the bond length of $\mathrm{Cd}$ to its $\mathrm{S}$ donor atoms was $2.48 \AA$, which was slightly shorter than the experimental data of Cd-cysteine 2.52-2.54 $\AA$ (Jalilehvand et al., 2009). Glutathione, $\gamma$-Glu-Cys-Gly, is a thiol-containing tripeptide, and the ligands of 1:2 Cd-glutathione complexes (Fig. 11) are $\mathrm{GS}^{3-}$ molecules with amide protons, where $\mathrm{Cd}$ has a tetrahedral coordination sphere and the complex primarily involves two deprotonated thiol groups from cysteine residues and two water molecules (Delalande et al., 2010). EXAFS spectra of Cd-glutathione complexes suggested $\mathrm{Cd}$ was fourfold coordination and $\mathrm{S}$ atoms were identified as the binding atoms at $2.54 \pm 0.1 \AA$ (Isaure et al., 2015). The calculated Cd-S mean bond distance in

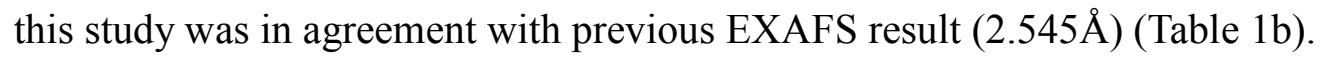

\subsection{Comparison with experimental vibrational frequencies}

Only a few experimentally determined vibrational frequencies exist for organic $\mathrm{Cd}$ complexes since they are difficult to determine experimentally. Richet et al. (1977) thought the effects of anharmonicity on the isotope fractionation are expected to be 
quite small, here only harmonic vibration was considered. Table 2 lists the calculated harmonic vibrational frequencies of the ${ }^{114} w$ isotopomer and ${ }^{110} w$ isotopomer of $\mathrm{Cd}(\mathrm{Hcit})\left(\mathrm{H}_{2} \mathrm{cit}\right)^{-}$and the experimental data by FTIR (Bertoli et al., 2015). The frequency shifts values $10^{3}\left(1-{ }^{114} w /{ }^{110} w\right)$ of $\mathrm{Cd}$ isotopes are also listed.

In Table $2, w_{1}$ is the twisting vibration mode of $\mathrm{H}-\mathrm{C}-\mathrm{H}$ with stretching vibration mode of C-O, the experimental vibrational frequencies by Bertoli et al. (2015) was $1027.05 \mathrm{~cm}^{-1}$, the calculated data by this study were $1041.1681 \mathrm{~cm}^{-1}$ for ${ }^{114} w$ isotopomer and $1041.1686 \mathrm{~cm}^{-1}$ for ${ }^{110} w$ isotopomer, the average value of the calculated frequency of the two isotopomers is about $1.375 \%$ higher than experimental data. $w_{2}$ is the rocking vibration mode of $\mathrm{H}-\mathrm{C}-\mathrm{H}$ with stretching vibration mode of $\mathrm{C}-\mathrm{C}$, the experimental data was $1078.98 \mathrm{~cm}^{-1}$, the calculated frequencies were $1079.978 \mathrm{~cm}^{-1}$ for $\mathrm{Cd}$ heavy isotope and $1079.9783 \mathrm{~cm}^{-1}$ for the light one, the average frequency values by this calculation is $0.093 \%$ higher than experimental data. $w_{3}$ is the twisting vibration mode of $\mathrm{H}-\mathrm{C}-\mathrm{H}$ with stretching vibration mode of $\mathrm{C}-\mathrm{C}$, the calculated average data is $1.041 \%$ lower than experimental data. $w_{4}$ is the scissoring vibration mode of $\mathrm{H}-\mathrm{C}-\mathrm{H}$, the average data by calculation is close to the experimental data and the calculated average frequency is $0.490 \%$ lower than experimental data. $w_{5}$ is the rocking vibration mode of $\mathrm{H}-\mathrm{C}-\mathrm{H}$ with stretching vibration mode of $\mathrm{C}-\mathrm{C}$ and $\mathrm{C}-\mathrm{O}$, the average data by calculation is $0.698 \%$ higher than experimental data. $w_{6}$ is the wagging vibration mode of $\mathrm{H}-\mathrm{C}-\mathrm{H}$ with scissoring vibration mode of $\mathrm{O}-\mathrm{H}$, the frequency difference between experiment and the average theory calculation is $0.142 \%$. The $w_{7}$ is the symmetrical stretching vibration and the 
271 difference between calculation and experiment is $0.310 \%$. $w_{8}$ is the symmetrical 272 stretching vibration mode of $\mathrm{COO}^{-}$, the difference of calculated data and experimental 273 data is $0.069 \%$. $w_{9}$ is asymmetrical stretching vibration of $\mathrm{COO}^{-}$, the average 274 frequency calculated is $3.187 \%$ higher than experimental results. For $w_{10}$, it is 275 stretching vibration mode and the calculated result is $0.652 \%$ lower than experimental 276 data (Table 2). Overall, the calculated frequencies were generally consistent with 277 previously experimental data of $\mathrm{Cd}(\mathrm{Hcit})\left(\mathrm{H}_{2} \mathrm{cit}\right)^{-}$.

278 The accuracy of vibrational frequencies can be further propagated in the final $27910^{3} \ln \beta$ values (Schauble et al., 2003, 2004; Schauble et al., 2007). Frequency scaling 280 factors can often be used to correct the calculated vibrational frequencies which are 281 able to reproduce the experimental frequencies. However, the simple harmonic 282 frequency calculated by quantum chemistry methods need to be corrected when it is 283 used to calculate isotope fractionation involving larger molecules (Liu et al., 2010; 284 Fujii et al., 2014). Here frequency scaling factors were not needed in this study.

\subsection{Reduced partition function ratios, $10^{3} \ln \left(\beta_{114-110}\right)$ for $C d$ complexes}

$\mathrm{Cd}$ species have been studied. The calculated reduced partition function ratios 
293

294

295

calculated in this study are reported in Table $3 .{ }^{114} \mathrm{Cd}$ and ${ }^{110} \mathrm{Cd}$ have the largest mass difference among Cd isotopes (Carignan et al., 2004; Wombacher and Rehkämper, 2004), usually ${ }^{114} \mathrm{Cd} /{ }^{110} \mathrm{Cd}$ isotope ratios were chosen to study the $\mathrm{Cd}$ isotope fractionation of $\mathrm{Cd}$ partitioning into different chemical complexes. Mass-dependent isotope fractionation is a function of temperature $(T)$, and can be expressed as below:

$$
10^{3} \ln \left(\beta_{114-110}\right)=A \times \frac{10^{6}}{T^{2}}+B
$$

Where $A, B$ are the regression parameters, which can be figured out from Table 3 . The A, B values of these complexes are listed in Table S2, for comparison their relationship also be figured in Fig. 2. Our calculation shows that the $10^{3} \ln \beta$ of ${ }^{114} \mathrm{Cd} /{ }^{110} \mathrm{Cd}$ for these complexes decreases in the order of $\mathrm{Cd}(\mathrm{Hcit})\left(\mathrm{H}_{2} \mathrm{cit}\right)^{-}>$ $\mathrm{Cd}(\mathrm{cit})\left(\mathrm{H}_{2} \mathrm{O}\right)_{3}{ }^{-}>\mathrm{CdH}(\mathrm{cit})\left(\mathrm{H}_{2} \mathrm{O}\right)_{4}>\mathrm{CdEDTA}>\mathrm{Cd}(\text { his })_{2} \mathrm{H}_{2} \mathrm{O}>\mathrm{Cd}(\mathrm{cit})_{2}{ }^{4-} \approx$ $\mathrm{Cd}\left(\mathrm{H}_{2} \mathrm{O}\right)_{6}{ }^{2+}>\mathrm{Cd}\left(\mathrm{H}_{2} \mathrm{O}\right)_{4}{ }^{2+}>\mathrm{Cd}(\mathrm{cys})\left(\mathrm{H}_{2} \mathrm{O}\right)_{3}{ }^{2+}>\mathrm{Cd}(\mathrm{GS})_{2}\left(\mathrm{H}_{2} \mathrm{O}\right)_{2}{ }^{2-}>\mathrm{Cd}(\mathrm{DMPS})\left(\mathrm{H}_{2} \mathrm{O}\right)_{2}{ }^{-}$ $>\mathrm{Cd}(\mathrm{DMPS})_{2}{ }^{4-}$ at $0 \sim 100^{\circ} \mathrm{C}$

Previous studies demonstrated that the types of donor atoms $(\mathrm{O}, \mathrm{N}, \mathrm{S})$ of organic ligands are a main driver for $\mathrm{Zn}$ isotope fractionation (Albarède et al., 2011; Fujii and Albarède, 2012; Balter et al., 2013; Moynier et al., 2013; Fujii et al., 2014). Particularly, $\mathrm{O}$ donors preferentially bind heavier $\mathrm{Zn}$ isotopes than $\mathrm{S}$ donors. $\mathrm{Cd}$ and $\mathrm{Zn}$ are in the same group in the periodic table which means that the two elements have the same number of electrons in their outer valence shell. Thus, the elements share similar chemical properties such as a flexible coordination chemistry, they are nonredox sensitive, and have similar stability constants (John et al., 2017; Maret and Moulis, 2013; Sóvágó and Várnagy, 2013). It is likely that O, N, and S donor atoms 
may have a similar effect on $\mathrm{Cd}$ isotope fractionation as they do for $\mathrm{Zn}$. This hypothesis has been recently partly verified by Yang et al. (2015) who reported an enrichment of heavy $\mathrm{Cd}$ isotopes for $\mathrm{O}$ and $\mathrm{N}$ compared to $\mathrm{S}$ donors of inorganic ligands. In addition, studies on $\mathrm{Zn}$ isotopes have shown that the number of coordination for the same donor atoms can also determine isotope fractionation (Fujii et al., 2014). For instance, fourfold coordinated Zn-amino acid complexes had larger $10^{3} \ln \left(\beta_{114-110}\right)$ values than the sixfold coordinated complexes of the same amino acid. The relationship between the $10^{3} \ln \left(\beta_{114-110}\right)$ values and donor atoms type of the $\mathrm{Cd}$ complexes at $25^{\circ} \mathrm{C}$ is given in Fig. 3 (the types and numbers of donor atoms are given in Table $\mathrm{S} 3$ ). For Cd complexes, $\mathrm{S}$ or combinations of $\mathrm{S}$ and $\mathrm{O}$ donor atoms tended to complex with lighter $\mathrm{Cd}$ isotopes. Furthermore, the $10^{3} \ln \left(\beta_{114-110}\right)$ disparities induced by $\mathrm{S}$ and $\mathrm{S} / \mathrm{O}$ donor atoms were bigger than those by $\mathrm{O}$ and $\mathrm{O} / \mathrm{N}$ donor atoms. The relationship between $10^{3} \ln \left(\beta_{114-110}\right)$ and mean bond lengths of $\mathrm{Cd}$ to its donor atoms at $25^{\circ} \mathrm{C}$ was shown in Fig. 4. Overall, mean coordinated bond lengths of complexes with O donor atoms were shorter than those with $\mathrm{S}$ donor atoms, except $\mathrm{Cd}(\mathrm{cys})\left(\mathrm{H}_{2} \mathrm{O}\right)_{3}{ }^{2+}$. The reason may be that $\mathrm{Cd}(\mathrm{cys})\left(\mathrm{H}_{2} \mathrm{O}\right)_{3}{ }^{2+}$ has three $\mathrm{O}$ donors and one $\mathrm{S}$ donor.

Among all studied $\mathrm{Cd}$ complexes, $\mathrm{Cd}(\mathrm{Hcit})\left(\mathrm{H}_{2} \text { cit }\right)^{-}$has the largest $10^{3} \ln \left(\beta_{114-110}\right)$ values while $\mathrm{Cd}(\mathrm{DMPS}){ }_{2}{ }^{4-}$ has the smallest $10^{3} \ln \left(\beta_{114-110}\right)$ values (Fig. 2 and Table 3 ), their difference can reach 1.18 at $25^{\circ} \mathrm{C}$. Cd-citrate complexes can be fourfold coordinated $\left(\mathrm{Cd}(\mathrm{Hcit})\left(\mathrm{H}_{2} \mathrm{cit}\right)^{-}\right.$and $\left.\mathrm{Cd}(\mathrm{cit})_{2}{ }^{4-}\right)$ and sixfold coordinated $\left(\mathrm{CdH}(\mathrm{cit})\left(\mathrm{H}_{2} \mathrm{O}\right)_{4}\right.$ and $\left.\mathrm{Cd}(\mathrm{cit})\left(\mathrm{H}_{2} \mathrm{O}\right)_{3^{-}}\right)$, and their $10^{3} \ln \left(\beta_{114-110}\right)$ values can differ up to 0.213 at $25^{\circ} \mathrm{C}$ which means that the structure difference of these Cd-citrate complexes can result in 
337 Cd isotope fractionation (Fig. 1, 2). In addition, $10^{3} \ln \left(\beta_{114-110}\right)$ values of fourfold 338 coordinated $\mathrm{Cd}(\mathrm{Hcit})\left(\mathrm{H}_{2} \mathrm{cit}\right)^{-}$were larger than those of sixfold coordinated $339 \mathrm{CdH}(\mathrm{cit})\left(\mathrm{H}_{2} \mathrm{O}\right)_{4}$ and $\mathrm{Cd}(\mathrm{cit})\left(\mathrm{H}_{2} \mathrm{O}\right)_{3}{ }^{-}$, but those of $\mathrm{Cd}(\mathrm{cit})_{2}{ }^{4-}$ are smaller than those of $340 \mathrm{CdH}(\mathrm{cit})\left(\mathrm{H}_{2} \mathrm{O}\right)_{4}$ and $\mathrm{Cd}(\mathrm{cit})\left(\mathrm{H}_{2} \mathrm{O}\right)_{3}{ }^{-}$. Thus, for Cd-citrate complexes, the coordination 341 number is only one of the factors that have an effect on $\mathrm{Cd}$ isotope fractionation, 342 when estimating Cd isotope fractionation of them, other factors should be considered. 343 The Cd-cysteine, Cd-GSH, and Cd-DMPS complexes contain S donor atoms. Our 344 calculations revealed that these $C d$ complexes had lower $10^{3} \ln \left(\beta_{114-110}\right)$ values in 345 comparison with hydrated $\mathrm{Cd}$ complexes and organic $\mathrm{Cd}$ complexes that contained $\mathrm{O}$ 346 and $\mathrm{N}$ donor atoms (Table 3 and Fig. 3). The lower $10^{3} \ln \left(\beta_{114-110}\right)$ values in $\mathrm{S}$ 347 containing ligands is in agreement with previous studies that reported $10^{3} \ln \beta$ values 348 for inorganic Cd (Yang et al., 2015) and organic Zn complexes (Fujii et al., 2014). 349 Among the complexes that contained $\mathrm{S}$ and $\mathrm{O}$ donor atoms in this study, their $35010^{3} \ln \left(\beta_{114-110}\right)$ values slightly differed. For instance, $\mathrm{Cd}(\mathrm{DMPS})\left(\mathrm{H}_{2} \mathrm{O}\right)_{2}^{-}$and $351 \mathrm{Cd}(\mathrm{GS})_{2}\left(\mathrm{H}_{2} \mathrm{O}\right)_{2}{ }^{2-}$ were complexed with two $\mathrm{S}$ donor atoms from the organic 352 molecules and two $\mathrm{O}$ donor atoms from water molecules. The average bond lengths of $353 \mathrm{Cd}-\mathrm{S}$ in $\mathrm{Cd}(\mathrm{DMPS})\left(\mathrm{H}_{2} \mathrm{O}\right)_{2}{ }^{-}(2.48 \AA)$ was shorter than that in $\mathrm{Cd}(\mathrm{GS})_{2}\left(\mathrm{H}_{2} \mathrm{O}\right)_{2}{ }^{2-}(2.545$ $354 \AA$, Table 1 and S3). The average Cd-O bond lengths in $\mathrm{Cd}(\mathrm{DMPS})\left(\mathrm{H}_{2} \mathrm{O}\right)_{2}{ }^{-}(2.95 \AA)$ 355 were longer than that of $\mathrm{Cd}(\mathrm{GS})_{2}\left(\mathrm{H}_{2} \mathrm{O}\right)_{2}{ }^{2-}(2.415 \AA)$. Our data suggests that chelators 356 with $\mathrm{S}$ ligands significantly change the bond lengths between $\mathrm{Cd}$ and other donor 357 atoms than $\mathrm{S}$ which might contribute to the lower $10^{3} \ln \left(\beta_{114-110}\right)$ value in the chelating 358 Cd(DMPS $)_{2}^{4-}$ complex. 

with four $\mathrm{S}$ and no $\mathrm{O}$ donor atoms, was smaller compared to $\mathrm{Cd}(\mathrm{DMPS})\left(\mathrm{H}_{2} \mathrm{O}\right)_{2}^{-}$

(Table 3 and Fig. 3). This observation agrees with previously published calculations of $\mathrm{Zn}$ sulfides where the smallest fractionation occurred in $\mathrm{Zn}$ sulfide complexes with four $\mathrm{S}$ donor atoms compared to $\mathrm{Zn}$ sulfide complexes contained mixtures of S and $\mathrm{O}$ donor atoms (Fujii et al., 2011). Together, our data suggests that a large shift towards light isotopes occurs when $\mathrm{Cd}$ is complexed to a chelating organic ligand with two or four $\mathrm{S}$ donor atoms when compared non-chelating $\mathrm{S}$ donor atoms and $\mathrm{O} / \mathrm{N}$ donor atoms in general. and $\mathrm{Cu}$ (Ryan et al., 2014) complexes reported a direct relation between the stability of complexes and the extent and isotope fractionation factors. This relation was also observed in our data, however, the difference of $10^{3} \ln \left(\beta_{114-110}\right)$ values between metal chelator CdEDTA and $\mathrm{Cd}(\text { his })_{2} \mathrm{H}_{2} \mathrm{O}$ was comparably small $\left(0.027\right.$ at $25^{\circ} \mathrm{C}$, Fig. 2 and Table 3). Though CdEDTA forms more stable complexes than Cd-histidine complexes (Sóvágó and Várnagy, 2013; Karak et al., 2016), the coordination number was six for both complexes while the CdEDTA had four $\mathrm{O}$ and two $\mathrm{N}$ donor atoms and $\mathrm{Cd}(\text { his })_{2} \mathrm{H}_{2} \mathrm{O}$ had four $\mathrm{N}$ and two $\mathrm{O}$ donor atoms, and the average bond lengths 377 between the central $\mathrm{Cd}$ atom and its donor atoms were very similar: CdEDTA 2.367 fractionation between the two complexes might have been demonstrated by the 
381

382

383

384

385

386

387

388

389

390

391

392

393

394

395

396

397

398

399

400

401

402

distinct coordination and bond lengths of the two complexes.

\subsection{Error analysis for Cd isotope fractionation}

Vacuo and solvation models can cause isotope fractionation factors inaccuracies (Hill and Schauble, 2008; Yang et al., 2015). In ideal vacuum gaseous conditions, the influence of the surrounding environment such as solvents on the solute molecules in the real system is ignored. To overcome this limitation, some solvent models were established to simulate the effects of solvents on solutes. The polarized continuum models (PCMs) are widely used to simulate the aqueous environment (Tomasi et al., 2005; Tsipis, 2014). However, Yang et al. (2015) found that the bond lengths optimized by IEFPCM model are larger than those by vacuo model and the $10^{3} \ln \left(\beta_{114}\right.$ 110) results calculated in the IEFPCM model are smaller than those in vacuo model, and thought that the optimized structures and $\ln \beta$ values of $\mathrm{Cd}$ complexes calculated in vacuo are more consistent with the experimental data. For comparison, the implicit solvation models IEFPCM (the integral-equation-formalism versions of PCM) and CPCM (conductor-like PCM) were used to calculate the optimized molecular structures and $10^{3} \ln \left(\beta_{114-110}\right)$ at $25^{\circ} \mathrm{C}$ for studied complexes (Table $\mathrm{S} 4$ and S5), as well as the model of $\mathrm{Cd}\left(\mathrm{H}_{2} \mathrm{O}\right)_{6}{ }^{2+}$ with second hydration sphere $\mathrm{Cd}\left(\mathrm{H}_{2} \mathrm{O}\right)_{18}{ }^{2+}$ (Table S6).

Our calculation showed that most of the bond lengths optimized in solution by this study were larger than those in vacuum (Table S4). This was agreement with the results of inorganic $\mathrm{Cd}$ complexes (Yang et al., 2015). For $10^{3} \ln \left(\beta_{114-110}\right)$ values, not 
403

404

405

406

407

408

409

410

411

412

413

414

415

416

417

418

419

420

421

422

423

424

only does difference exist between two implicit models and vacuum model but also between two implicit models. By comparing with vacuum model, IEFPCM and CPCM solvation models decrease the $10^{3} \ln \beta$ of $\mathrm{Cd}\left(\mathrm{H}_{2} \mathrm{O}\right)_{4}{ }^{2+}$ by 0.346 and 0.221 at $25^{\circ} \mathrm{C}$ respectively, and increase the $10^{3} \ln \beta$ of $\mathrm{Cd}\left(\mathrm{H}_{2} \mathrm{O}\right)_{6}{ }^{2+}$ by 0.139 and 0.166 at $25^{\circ} \mathrm{C}$ respectively. For $\mathrm{Cd}(\mathrm{Hcit})\left(\mathrm{H}_{2} \mathrm{cit}\right)^{-}, \mathrm{CdH}(\mathrm{cit})\left(\mathrm{H}_{2} \mathrm{O}\right)_{4}, \mathrm{Cd}(\mathrm{cit})\left(\mathrm{H}_{2} \mathrm{O}\right)_{3}{ }^{-}$and $\mathrm{Cd}(\text { his })_{2} \mathrm{H}_{2} \mathrm{O}$, IEFPCM and CPCM model decrease the $10^{3} \ln \beta$ by $0.175-0.580$ and $0.206-0.567$ and increase the $10^{3} \ln \beta$ of $\mathrm{Cd}(\mathrm{cys})\left(\mathrm{H}_{2} \mathrm{O}\right)_{3}{ }^{2+}$ by 0.281 and 0.401 at $25^{\circ} \mathrm{C}$ respectively. For $\mathrm{Cd}(\mathrm{cit}){ }_{2}{ }^{4-}, \mathrm{CdEDTA}, \mathrm{Cd}(\mathrm{DMPS})_{2}{ }^{4-}$, these two models increase the $10^{3} \ln \beta$ by less than 0.1 at $25^{\circ} \mathrm{C}$. For $\mathrm{Cd}(\mathrm{GS})_{2}\left(\mathrm{H}_{2} \mathrm{O}\right)_{2}{ }^{2-}$, the IEFPCM solvation model decrease the $10^{3} \ln \beta$ by 0.109 and $\mathrm{CPCM}$ model increase the $10^{3} \ln \beta$ by less than 0.1 at $25^{\circ} \mathrm{C}$, the implicit solvation models have different effects on Cd isotope fractionation (Table S5). The main reason may be that the simple harmonic vibrational frequencies have been polluted by translation and rotation which make the inaccurate for frequencies data in solvation models (Yang et al., 2015), and the levels of "pollution" may be different for different Cd complexes.

Setting the second hydration sphere is able to make the calculated frequencies closer to the experimental values and improve the $10^{3} \ln \beta$ for Ni and $\mathrm{Zn}$ (Fujii et al., 2014), the same phenomenon may occur in Cd hydrate species. Our calculation showed that for $\mathrm{Cd}\left(\mathrm{H}_{2} \mathrm{O}\right)_{6}{ }^{2+}$, the $10^{3} \ln \beta$ values for the explicit model as $\mathrm{Cd}\left(\mathrm{H}_{2} \mathrm{O}\right)_{18}{ }^{2+}$ is 2.377 and 1.990, 1.923 for explicit model + IEFPCM and explicit model + CPCM at $25^{\circ} \mathrm{C}$ respectively. Compared with the vacuum model, the explicit model increases the $10^{3} \ln \beta$ values and explicit + implicit model decrease them (Table S6). The total 
symmetric stretching mode of hexaaqua complexes, $v_{1} \mathrm{CdO}_{6}$, is shown in Table S6. The calculated $v_{1}$ frequency values of large cluster $\mathrm{Cd}\left(\mathrm{H}_{2} \mathrm{O}\right)_{18}{ }^{2+}, \mathrm{Cd}\left(\mathrm{H}_{2} \mathrm{O}\right)_{6}{ }^{2+}+$ IEFPCM and $\mathrm{Cd}\left(\mathrm{H}_{2} \mathrm{O}\right)_{6}{ }^{2+}+\mathrm{CPCM}$ are closer to previous calculation and experimental data than that of $\mathrm{Cd}\left(\mathrm{H}_{2} \mathrm{O}\right)_{6}{ }^{2+}$ (Table S6), which means solvation models make the frequency values closer the literature values and the solvent effect on $10^{3} \ln \beta$ values are needed to be considered.

Frequency is another most frequently mentioned factor that may cause uncertainties or errors of the calculated reduced partition function ratios (Schauble et al., 2003, 2004; Schauble et al., 2007; Méheut et al., 2007, 2009; Weeks et al., 2007; Yang et al., 2015). For lack of experimental vibrational frequency of $\mathrm{Cd}$ organic complexes, it is impossible to evaluate the RPFR errors for them, and different vibration frequencies may lead to discrepant uncertainty in $10^{3} \ln \left(\beta_{114-110}\right)$ values at $25 \square$ (Vogt et al., 1993; Schauble, 2007; Yang et al., 2015). Based on existing experimental frequency data of $\mathrm{Cd}(\mathrm{Hcit})\left(\mathrm{H}_{2} \mathrm{cit}\right)^{-}$and this calculation, the maximum difference between them is $3.187 \%$, and the average deviation is about $0.293 \%$. Based on Schauble $(2007,2011)$, calculated frequencies may lead to an error of less than $0.6 \%$ for $10^{3} \ln \left(\beta_{114-110}\right)$ values of $\mathrm{Cd}(\mathrm{Hcit})\left(\mathrm{H}_{2} \mathrm{cit}\right)^{-}$.

\subsection{Implications for Cd process tracing applications in biogeochemistry, supergene} geochemistry and environmental science

Metal isotope fractionation can be used to trace processes that control the 
distribution of an element in terrestrial and aquatic environments. Previous experimental studies hypothesized that the Cd isotope fractionation is strongly linked to $\mathrm{Cd}$ speciation to organic ligands with $\mathrm{S}$ donor atoms to detoxify and immobilize $\mathrm{Cd}$ in living organisms (Horner et al., 2013; Wiggenhauser et al., 2016, 2021; Imseng et al., 2019). Results by this study and Yang et al. (2015) revealed that an enrichment of light isotopes occurs in thiol ligands when compared to hydrated $\mathrm{Cd}$ and $\mathrm{Cd}$ bound to $\mathrm{O} / \mathrm{N}$ donor atoms of organic ligands, which will strengthen not only $\mathrm{Cd}$ isotopes as a process tracing tool, but also the understanding of $\mathrm{Cd}$ isotope cycling in aquatic and terrestrial systems. For example, to reduce inputs of the toxic trace metal $\mathrm{Cd}$ into the food chain of humans and animals, processes that control the mobility of $\mathrm{Cd}$ in terrestrial and aquatic environments need to be well understood. The results that heavy $\mathrm{Cd}$ isotopes preferably bind to oxygen and nitrogen donor atoms while light $\mathrm{Cd}$ isotopes bind to sulfur donor atoms of organic ligands compared to hydrated $\mathrm{Cd}^{2+}$ provides information on processes on the immobilization of $\mathrm{Cd}$ isotopes in living organisms which are related to Cd detoxification processes with sulfur.

Furthermore, the strongest $\mathrm{Cd}$ isotope fractionation compared to hydrated $\mathrm{Cd}$ occurred in chelating S donor ligands, particularly in a chelating S donor ligand in which $\mathrm{Cd}$ is exclusively bound to $\mathrm{S}$. Thus, our data confirms the hypothesis that the retention of light isotopes in roots and shoots of grasses (Wiggenhauser et al., 2016, 2021; Imseng et al., 2019) and membranes of E.Coli (Horner et al., 2013) could be induced by the immobilization of light $\mathrm{Cd}$ isotopes through strong $\mathrm{Cd}$ binding to chelators with S donor atoms such as phytochelatins (Clemens et al. 2019). This 
469

470

471

472 induced by chelating thiols may have implications on $\mathrm{Cd}$ isotope fractionation in other

473

474

475

476

477

478

479

480

481

482

483

484

485

486

487

chelation would retain light $\mathrm{Cd}$ isotopes e.g., in the roots of cereals, while other chemical Cd species such as hydrated Cd that are enriched in heavy isotopes can be transported by membrane proteins towards the shoot. The $\mathrm{Cd}$ isotope fractionation plants than grasses. Cd hyperaccumulator plants can cope with high $\mathrm{Cd}$ concentrations and store, unlike cereals, the majority of the Cd taken up from soils in their shoots (Zhou et al. 2020). To cope with the high Cd shoot concentrations, Cd is mostly bound to $\mathrm{O}$ donor atoms of e.g., organic acids and to a lesser extent to $\mathrm{S}$ donors (Tian et al. 2011; Isaure et al. 2015). Based on our findings, the Cd isotope fractionation in $\mathrm{Cd}$ accumulating plants could potentially provide novel insights into the role of $\mathrm{Cd}$ binding to different donor atoms on the translocation of $\mathrm{Cd}$ within the shoot. Recent studies focused on $\mathrm{Cd}$ isotope fractionation in cacao since cacao beans often exceed the threshold values for $\mathrm{Cd}$ potentially leading to elevated $\mathrm{Cd}$ concentrations in chocolate (Moore et al. 2020; Barraza et al. 2019). Similar to grasses such as wheat, rice, and barley, cacao seems to retain $\mathrm{Cd}$ and its light isotopes in the roots (Moore et al. 2020). Our findings suggest that Cd binding to thiols may play also a crucial role to retain $\mathrm{Cd}$ in roots of cacao and thereby limit the $\mathrm{Cd}$ transport into cacao beans.

Our results further suggest that Cd ligands, especially thiols, may play a key role in $\mathrm{Cd}$ isotope fractionation in living organisms, soils, and waters. In this study, the $\mathrm{Cd}$ isotope fractionation between hydrated $\mathrm{Cd}$ and $\mathrm{Cd}$ chelated by $\mathrm{S}$ donor atoms was 1\%. The largest $\mathrm{Cd}$ isotope fractionation that has been observed between roots and shoots of plants that strongly retain light $\mathrm{Cd}$ isotopes in roots was around $0.60 \%$ 
491 (Wiggenhauser et al. 2016, 2021; Imseng et al. 2018; Moore et al. 2020). The 492 difference between our results and the experimentally determined $\mathrm{Cd}$ isotopes 493 fractionation between root and shoots may be caused by additional isotope effects that 494 complement isotope effects at equilibrium. The transfer from root to shoot includes membrane transport (Deng et al. 2019). This transport requires fast binding of $\mathrm{Cd}$ to a metal binding site of a membrane protein prior to unidirectional membrane transport

497 (Wang et al., 2014; Zhao et al., 2016). Thus, membrane transport might be at least 498 partly kinetically controlled (Köbberich and Vance, 2017). Kinetically controlled processes favor light isotopes through their faster reaction rates (Wiederhold, 2015) while type of metal binding sites of a membrane transproters (e.g., cysteine, histidine) might play an additional role for isotope fractionation during membrane transport.

502 Together, our results suggest that equilibrium $\mathrm{Cd}$ isotope fractionation in plants 503 induced by binding of $\mathrm{Cd}$ to organic molecules occur in parallel to kinetic isotope 504 effects.

505 In soils, sediments, and water, organic matter poses an important binding site for $506 \mathrm{Cd}$ and partly controls the mobility of $\mathrm{Cd}$. For instance, soil organic matter derives 507 from decomposed biomass and provides a mixture of $\mathrm{O}, \mathrm{N}$, and $\mathrm{S}$ donor atoms for $\mathrm{Cd}$ 508 in the solid and liquid phase of the soil (Karlsson et al., 2007; Tiberg et al., 2018).

509 Besides processes such as Cd sulfide precipitation and Cd uptake into phytoplankton, 510 soluble organic ligands might significantly control the $\mathrm{Cd}$ distribution in water 511 columns and sediments during the oceanic Cd cycle (Guinoiseau et al., 2018). Our 512 data implies that $\mathrm{Cd}$ sorption of $\mathrm{Cd}$ to organic matter can enrich or deplete the 
513

514

515

516

517

518

519

520

521

522

523

524

525

526

527 tracing tool in complex biological systems and further improve the understanding of

528 Cd isotope cycling in aquatic and terrestrial systems.

This research was supported financially by the National Natural Science Foundation of China (No. 41872160); the Key Project of National Natural Science Foundation of China (No. 41530315); the DREAM project of MOST of China (2016YFC0600401); 
535

536

537

538

539

540

541

542

543

544

545

546

547

548

549

550

551

552

553

554

555

556

and the Swiss national research foundation (Early Postdoc.mobility, P2EZP2178618). We are also grateful for Professor Wang Zhixiang who provided us the chance to conduct this study.

\section{Appendices. Supplementary material}

Table S1: Comparing the experimental vibrational frequencies with calculated results $\left({ }^{110} w\right)$ employed by four different exchange correlation functionals for $\mathrm{Cd}(\mathrm{Hcit})\left(\mathrm{H}_{2} \text { cit }\right)^{-}$. Table S2: The fitting factors $\mathrm{A}, \mathrm{B}$ for $10^{3} \ln \left(\beta_{114-110}\right)=\mathrm{A} \times 10^{6} / \mathrm{T}^{2}+\mathrm{B}(\mathrm{T}$ is K). Table S3: The donor atoms, coordinated bond lengths $(\AA)$ and mean bond lengths $(\AA)$ for Cd complexes. Table S4a: Optimized bond lengths $(\AA)$ of the Cd hydration complexes and citrate complexes calculated with solvation models. Table S4b: Optimized bond lengths $(\AA)$ of the organic Cd complexes calculated with solvation models. Table S5: The $10^{3} \ln \left(\beta_{114-110}\right)$ of Cd complexes calculated in vacuo and solvation models (IEFPCM, CPCM) at $25^{\circ} \mathrm{C}$. Table S6: The vibrational frequencies $\left({ }^{110} w\right)$ and $10^{3} \ln \beta$ values of $\mathrm{Cd}\left(\mathrm{H}_{2} \mathrm{O}\right)_{6}{ }^{2+}$ and $\mathrm{Cd}\left(\mathrm{H}_{2} \mathrm{O}\right)_{18^{2+}}$.

\section{References}

Albarede, F., Télouk, P., Balter, V., Bondanese, V.P., Albalat, E., Oger, P., Bonaventura, P., Miossec, P., Fujii, T., 2016. Medical applications of Cu, Zn, and S isotope effects. Metallomics 8, 1056-1070. 
Albarède, F., Telouk, P., Lamboux, A., Jaouen, K., Balter, V., 2011. Isotopic evidence of unaccounted for Fe and $\mathrm{Cu}$ erythropoietic pathways. Metallomics 3, 926-933.

Balter, V., Lamboux, A., Zazzo, A., Télouk, P., Leverrier, Y., Marvel, J., Moloney, A.P., Monahan, F.J., Schmidt, O., Albarède, F., 2013. Contrasting Cu, Fe, and $\mathrm{Zn}$ isotopic patterns in organs and body fluids of mice and sheep, with emphasis on cellular fractionation. Metallomics 5, 1470-1482.

Becke, A.D., 1993a. Density- functional thermochemistry. III. The role of exact exchange. J. Chem. Phys. 98, 5648-5652.

Becke, A.D., 1993b. A new mixing of Hartree-Fock and local density- functional theories. J. Chem. Phys. 98, 1372-1377.

Bertoli, A.C., Carvalho, R., Freitas, M.P., Ramalho, T.C., Mancini, D.T., Oliveira, M.C., de Varennes, A., Dias, A., 2015. Theoretical spectroscopic studies and identification of metal-citrate $(\mathrm{Cd}$ and $\mathrm{Pb})$ complexes by ESI-MS in aqueous solution. Spectrochim. Acta Part A Mol. Biomol. Spectrosc. 137, 271-280.

Bigalke, M., Weyer, S., Wilcke, W., 2010. Copper isotope fractionation during complexation with insolubilized humic acid. Environ. Sci. Technol. 44, 54965502.

Bigeleisen, J., Mayer, M.G., 1947. Calculation of equilibrium constants for isotopic exchange reactions. J. Chem. Phys. 15, 261-267.

Cao, Z.-Y., Sun, L.-H., Mou, R.-X., Zhou, R., Zhu, Z.-W., Chen, M.-X., 2014. A novel method for the simultaneous analysis of seven biothiols in rice (Oryza sativa L.) using hydrophilic interaction chromatography coupled with 
Cao, Z.-Z., Qin, M.-L., Lin, X.-Y., Zhu, Z.-W., Chen, M.-X., 2018. Sulfur supply reduces cadmium uptake and translocation in rice grains (Oryza sativa L.) by enhancing iron plaque formation, cadmium chelation and vacuolar sequestration. Environ. Pollut. 238, 76-84.

Carignan, J., Cardinal, D., Eisenhauer, A., Galy, A., Rehkämper, M., Wombacher, F., Vigier, N., 2004. A reflection on $\mathrm{Mg}, \mathrm{Cd}, \mathrm{Ca}, \mathrm{Li}$ and $\mathrm{Si}$ isotopic measurements and related reference materials. Geostand. Geoanalytical Res. 28, 139-148.

Chrastný, V., Čadková, E., Vaněk, A., Teper, L., Cabala, J., Komárek, M., 2015. Cadmium isotope fractionation within the soil profile complicates source identification in relation to $\mathrm{Pb}-\mathrm{Zn}$ mining and smelting processes. Chem. Geol. 405, 1-9.

Clark, T., Chandrasekhar, J., Spitznagel, G.W., Schleyer, P.V.R., 1983. Efficient diffuse function-augmented basis sets for anion calculations. III. The $3-21+\mathrm{G}$ basis set for first-row elements, Li-F. J. Comput. Chem. 4, 294-301.

Clemens, S., 2019. Metal ligands in micronutrient acquisition and homeostasis. Plant. Cell Environ. 42, 2902-2912.

Clemens, S., Deinlein, U., Ahmadi, H., Höreth, S., Uraguchi, S., 2013. Nicotianamine is a major player in plant $\mathrm{Zn}$ homeostasis. BioMetals 26, 623-632.

Cloquet, C., Carignan, J., Libourel, G., Sterckeman, T., Perdrix, E., 2006. Tracing source pollution in soils using cadmium and lead isotopes. Environ. Sci. Technol. $40,2525-2530$. 
601

602

603

604

605

606

607

608

609

610

611

612

613

614

615

616

617

618

619

620

621

622

Colaneri, M.J., Vitali, J., Kirschbaum, K., 2013. Electron paramagnetic resonance spectroscopic study of copper hopping in doped bis(l-histidinato)cadmium dihydrate. J. Phys. Chem. A 117, 3414-3427.

Deng, F., Yu, M., Martinoia, E., Song, W.-Y., 2019. Ideal Cereals With Lower Arsenic and Cadmium by Accurately Enhancing Vacuolar Sequestration Capacity. Front. Genet. 10, 322.

Dennington, R., Keith, T., Millam, J., 2009. GaussView, Version 5.0.8. Semichem Inc.,Shawnee Mission, KS.

Delalande, O., Desvaux, H., Godat, E., Valleix, A., Junot, C., Labarre, J., Boulard, Y., 2010. Cadmium - glutathione solution structures provide new insights into heavy metal detoxification. FEBS J. 277, 5086-5096.

Francl, M.M., Pietro, W.J., Hehre, W.J., Binkley, J.S., Gordon, M.S., DeFrees, D.J., Pople, J.A., 1982. Self- consistent molecular orbital methods. XXIII. A polarization- type basis set for second- row elements. J. Chem. Phys. 77, 36543665.

Fransson, M. N., Barregard, L., Sällsten, G., Akerstrom, M., Johanson, G., 2014. Physiologically-based toxicokinetic model for cadmium using markov-chain monte carlo analysis of concentrations in blood, urine, and kidney cortex from living kidney donors. Toxicol. Sci. 141, 365-376.

Frisch, M.J., Trucks, G.W., Schlegel, H.B., Scuseria, G.E., Robb, M.A., Cheeseman, J.R., Scalmani, G., Barone, V., Mennucci, B., Petersson, G.A., Nakatsuji, H., Caricato, M., Li, X., Hratchian, H.P., Izmaylov, A.F., Bloino, J., Zheng, G., 
Sonnenberg, J.L., Hada, M., Ehara, M., Toyota, K., Fukuda, R., Hasegawa, J., Ishida, M., Nakajima, T., Honda, Y., Kitao, O., Nakai, H., Vreven, T., Montgomery Jr., J.A., Peralta, J.E., Ogliaro, F., Bearpark, M., Heyd, J.J., Brothers, E., Kudin, K.N., Staroverov, V.N., Kobayashi, R., Normand, J., Raghavachari, K., Rendell, A., Burant, J.C., Iyengar, S.S., Tomasi, J., Cossi, M., Rega, N., Millam, J. M., Klene, M., Knox, J.E., Cross, J.B., Bakken, V., Adamo, C., Jaramillo, J., Gomperts, R., Stratmann, R.E., Yazyev, O., Austin, A.J., Cammi, R., Pomelli, C., Ochterski, J.W., Martin, R.L., Morokuma, K., Zakrzewski, V.G., Voth, G.A., Salvador, P., Dannenberg, J.J., Dapprich, S., Daniels, A.D., Farkas, Ö., Foresman, J.B., Ortiz, J.V., Cioslowski, J., Fox, D.J., 2009. Gaussian 09, Revision A.01. Gaussian, Inc., Wallingford, CT

Fujii, T., Albarède, F., 2012. Ab initio calculation of the $\mathrm{Zn}$ isotope effect in phosphates, citrates, and malates and applications to plants and soil. PLoS One 7, e30726.

Fujii, T., Moynier, F., Blichert-Toft, J., Albarède, F., 2014. Density functional theory estimation of isotope fractionation of $\mathrm{Fe}, \mathrm{Ni}, \mathrm{Cu}$, and $\mathrm{Zn}$ among species relevant to geochemical and biological environments. Geochim. Cosmochim. Acta 140, 553-576.

Fujii, T., Moynier, F., Pons, M.-L., Albarède, F., 2011. The origin of Zn isotope fractionation in sulfides. Geochim. Cosmochim. Acta 75, 7632-7643.

Guinoiseau, D., Galer, S.J.G., Abouchami, W., 2018. Effect of cadmium sulphide precipitation on the partitioning of $\mathrm{Cd}$ isotopes: Implications for the oceanic $\mathrm{Cd}$ 
cycle. Earth Planet. Sci. Lett. 498, 300-308.

646

647

648

649

650

651

652

653

654

655

656

657

658

659

660

661

662

663

664

665

666

Gunawardana, B., Singhal, N., Johnson, A., 2010. Amendments and their combined application for enhanced copper, cadmium, lead uptake byLolium perenne. Plant Soil 329, 283-294.

Hay, P.J., Wadt, W.R., 1985. Ab initio effective core potentials for molecular calculations.Potentials for $\mathrm{K}$ to $\mathrm{Au}$ including the outer most core orbitals. J. Chem. Phys. 82, 299-310.

Hill, P.S., Schauble, E.A., 2008. Modeling the effects of bond environment on equilibrium iron isotope fractionation in ferric aquo-chloro complexes. Geochim. Cosmochim. Acta 72, 1939-1958.

Hoch, E., Lin, W., Chai, J., Hershfinkel, M., Fu, D., Sekler, I., 2012. Histidine pairing at the metal transport site of mammalian $\mathrm{ZnT}$ transporters controls $\mathrm{Zn}^{2+}$ over $\mathrm{Cd}^{2+}$ selectivity. Proc. Natl. Acad. Sci. 109, 7202-7207.

Hoefs, J., 2015. Isotope fractionation processes of selected elements BT - stable isotope geochemistry, in: Hoefs, J. (Ed.), . Springer International Publishing, Cham, pp. 47-190.

Horner, T.J., Lee, R.B.Y., Henderson, G.M., Rickaby, R.E.M., 2013. Nonspecific uptake and homeostasis drive the oceanic cadmium cycle. Proc. Natl. Acad. Sci. $110,2500-2505$.

Horner, T.J., Rickaby, R.E.M., Henderson, G.M., 2011. Isotopic fractionation of cadmium into calcite. Earth Planet. Sci. Lett. 312, 243-253.

Imseng, M., Wiggenhauser, M., Keller, A., Müller, M., Rehkämper, M., Murphy, K., 
Kreissig, K., Frossard, E., Wilcke, W., Bigalke, M., 2019. Towards an understanding of the Cd isotope fractionation during transfer from the soil to the cereal grain. Environ. Pollut. 244, 834-844.

Imseng, M., Wiggenhauser, M., Keller, A., Müller, M., Rehkämper, M., Murphy, K., Kreissig, K., Frossard, E., Wilcke, W., Bigalke, M., 2018. Fate of Cd in agricultural soils: a stable isotope approach to anthropogenic impact, soil formation, and soil-plant cycling. Environ. Sci. Technol. 52, 1919-1928.

Isaure, M.-P., Huguet, S., Meyer, C.-L., Castillo-Michel, H., Testemale, D., Vantelon, D., Saumitou-Laprade, P., Verbruggen, N., Sarret, G., 2015. Evidence of various mechanisms of $\mathrm{Cd}$ sequestration in the hyperaccumulator Arabidopsis halleri, the non-accumulator Arabidopsis lyrata, and their progenies by combined synchrotron-based techniques. J. Exp. Bot. 66, 3201-3214.

Jalilehvand, F., Leung, B.O., Mah, V., 2009. Cadmium(II) complex formation with cysteine and penicillamine. Inorg. Chem. 48, 5758-5771.

John, S.G., Kunzmann, M., Townsend, E.J., Rosenberg, A.D., 2017. Zinc and cadmium stable isotopes in the geological record: A case study from the postsnowball Earth Nuccaleena cap dolostone. Palaeogeogr. Palaeoclimatol. Palaeoecol. 466, 202-208.

Jouvin, D., Louvat, P., Juillot, F., Maréchal, C.N., Benedetti, M.F., 2009. Zinc isotopic fractionation: why organic matters. Environ. Sci. Technol. 43, 57475754.

Kabata-Pendias, A., 2011. Trace elements in soils and plants, 4. ed. ed. CRC Press, 
690

691

692

693

694

695

696

697

698

699

700

701

702

703

704

705

706

707

708

709

710

Karak, T., Paul, R.K., Das, D.K., Boruah, R.K., 2016. Complexation of DTPA and EDTA with $\mathrm{Cd}^{2+}$ : stability constants and thermodynamic parameters at the soilwater interface. Environ. Monit. Assess. 188, 670.

Karlsson, T., Elgh-Dalgren, K., Björn, E., Skyllberg, U., 2007. Complexation of cadmium to sulfur and oxygen functional groups in an organic soil. Geochim. Cosmochim. Acta 71, 604-614.

Khan, M.A., Castro-Guerrero, N., Mendoza-Cozatl, D.G., 2014. Moving toward a precise nutrition: preferential loading of seeds with essential nutrients over nonessential toxic elements. Front. Plant Sci. 5, 51.

Köbberich, M., Vance, D., 2017. Kinetic control on Zn isotope signatures recorded in marine diatoms. Geochim. Cosmochim. Acta 210, 97-113.

Kovács, A., Nemcsok, D.S., Kocsis, T., 2010. Bonding interactions in EDTA complexes. J. Mol. Struct. THEOCHEM 950, 93-97.

Krishnan, R., Binkley, J.S., Seeger, R., Pople, J.A., 1980. Self- consistent molecular orbital methods. XX. A basis set for correlated wave functions. J. Chem. Phys. $72,650-654$.

Lambelet, M., Rehkämper, M., van de Flierdt, T., Xue, Z., Kreissig, K., Coles, B., Porcelli, D., Andersson, P., 2013. Isotopic analysis of Cd in the mixing zone of Siberian rivers with the Arctic Ocean-New constraints on marine Cd cycling and the isotope composition of riverine Cd. Earth Planet. Sci. Lett. 361, 64-73.

Larner, F., McLean, C., Halliday, A., Roberts, B., 2019. Copper isotope compositions 
of superoxide dismutase and metallothionein from post-mortem human frontal cortex. Inorganics 7, 86.

Le Croizier, G., Lacroix, C., Artigaud, S., Le Floch, S., Munaron, J.-M., Raffray, J., Penicaud, V., Rouget, M.-L., Laë, R., Tito De Morais, L., 2019. Metal subcellular partitioning determines excretion pathways and sensitivity to cadmium toxicity in two marine fish species. Chemosphere $217,754-762$.

Lee, C., Yang, W., Parr, R.G., 1988. Development of the Colle-Salvetti correlationenergy formula into a functional of the electron density. Phys. Rev. B 37, 785789.

Leitenmaier, B., Witt, A., Witzke, A., Stemke, A., Meyer-Klaucke, W., Kroneck, P.M.H., Küpper, H., 2011. Biochemical and biophysical characterisation yields insights into the mechanism of a $\mathrm{Cd} / \mathrm{Zn}$ transporting ATPase purified from the hyperaccumulator plant Thlaspi caerulescens. Biochim. Biophys. Acta Biomembr. 1808, 2591-2599.

Li, D., Li, M.-L., Liu, W.-R., Qin, Z.-Z., Liu, S.-A., 2018. Cadmium isotope ratios of standard solutions and geological reference materials measured by MC-ICP-MS. Geostand. Geoanalytical Res. 42, 593-605.

Liu, Q., Tossell, J.A., Liu, Y., 2010. On the proper use of the Bigeleisen-Mayer equation and corrections to it in the calculation of isotopic fractionation equilibrium constants. Geochim. Cosmochim. Acta 74, 6965-6983.

Liu, Y., Xiao, T., Perkins, R.B., Zhu, J., Zhu, Z., Xiong, Y., Ning, Z., 2017. Geogenic cadmium pollution and potential health risks, with emphasis on black shale. J. 
Geochemical Explor. 176, 42-49.

Marentes, E., Rauser, W.E., 2007. Different proportions of cadmium occur as Cdbinding phytochelatin complexes in plants. Physiol. Plant. 131, 291-301.

Maret, W., Moulis, J.-M., 2013. The bioinorganic chemistry of cadmium in the context of its toxicity. Met. Ions Life Sci. 11, 1-29.

Marković, T., Manzoor, S., Humphreys-Williams, E., Kirk, G.J.D., Vilar, R., Weiss, D.J., 2017. Experimental determination of zinc isotope fractionation in complexes with the phytosiderophore 2'-deoxymugeneic acid (DMA) and its structural analogues, and implications for plant uptake mechanisms. Environ. Sci. Technol. 51, 98-107.

McLean, A.D., Chandler, G.S., 1980. Contracted Gaussian basis sets for molecular calculations. I. Second row atoms, Z=11-18. J. Chem. Phys. 72, 5639-5648.

McLean, J.E., Pabst, M.W., Miller, C.D., Dimkpa, C.O., Anderson, A.J., 2013. Effect of complexing ligands on the surface adsorption, internalization, and bioresponse of copper and cadmium in a soil bacterium, Pseudomonas putida. Chemosphere 91, 374-382.

Méheut, M., Lazzeri, M., Balan, E., Mauri, F., 2007. Equilibrium isotopic fractionation in the kaolinite, quartz, water system: Prediction from firstprinciples density-functional theory. Geochim. Cosmochim. Acta 71, 3170-3181.

Méheut, M., Lazzeri, M., Balan, E., Mauri, F., 2009. Structural control over equilibrium silicon and oxygen isotopic fractionation: A first-principles densityfunctional theory study. Chem. Geol. 258, 28-37. 
Moore, R.E.T., Ullah, I., de Oliveira, V.H., Hammond, S.J., Strekopytov, S., Tibbett, M., Dunwell, J.M., Rehkämper, M., 2020. Cadmium isotope fractionation reveals genetic variation in Cd uptake and translocation by Theobroma cacao and role of natural resistance-associated macrophage protein 5 and heavy metal ATPase-family transporters. Hortic. Res. 7, 71.

Morgan, J.L.L., Wasylenki, L.E., Nuester, J., Anbar, A.D., 2010. Fe Isotope fractionation during equilibration of $\mathrm{Fe}^{-}$organic complexes. Environ. Sci. Technol. 44, 6095-6101.

Moynier, F., Fujii, T., 2017. Theoretical isotopic fractionation of magnesium between chlorophylls. Sci. Rep. 7, 6973.

Moynier, F., Fujii, T., Shaw, A.S., Le Borgne, M., 2013. Heterogeneous distribution of natural zinc isotopes in mice. Metallomics 5, 693-699.

Pal, R., Kaur, R., Rajwar, D., Rai, J., 2019. Induction of non-protein thiols and phytochelatins by cadmium in Eichhornia crassipes. Int. J. Phytoremediation 21, $1-9$.

Pallavicini, N., Engström, E., Baxter, D.C., Öhlander, B., Ingri, J., Rodushkin, I., 2014. Cadmium isotope ratio measurements in environmental matrices by MCICP-MS. J. Anal. At. Spectrom. 29, 1570-1584.

Panfili, F., Schneider, A., Vives, A., Perrot, F., Hubert, P., Pellerin, S., 2009. Cadmium uptake by durum wheat in presence of citrate. Plant Soil 316, 299-309. Prévéral, S., Gayet, L., Moldes, C., Hoffmann, J., Mounicou, S., Gruet, A., Reynaud, F., Lobinski, R., Verbavatz, J.-M., Vavasseur, A., Forestier C., 2009. A common 
highly conserved cadmium detoxification mechanism from bacteria to humans: heavy metal tolerance conferred by the atp-binding cassette (abc) transporter sphmt1 requires glutathione but not metal-chelating phytochelatin peptides. J. Biol. Chem. 284, 4936-4943.

Puschenreiter, M., Gruber, B., Wenzel, W.W., Schindlegger, Y., Hann, S., Spangl, B., Schenkeveld, W.D.C., Kraemer, S.M., Oburger, E., 2017. Phytosiderophoreinduced mobilization and uptake of $\mathrm{Cd}, \mathrm{Cu}, \mathrm{Fe}, \mathrm{Ni}, \mathrm{Pb}$ and $\mathrm{Zn}$ by wheat plants grown on metal-enriched soils. Environ. Exp. Bot. 138, 67-76.

Ramalho, T.C., Figueroa-Villar, J.D., 2002. Thermodynamic evaluation of complexes of zinc and cadmium that mimetize metallic centers in transcription factors. J. Mol. Struct. THEOCHEM 580, 217-223.

Rehkämper, M., Wombacher, F., Horner, T.J., Xue, Z., 2011. Natural and anthropogenic $\mathrm{Cd}$ isotope variations. Handbook of Environmental Isotope Geochemistry. Springer, Berlin Heidelberg, pp. 125-154.

Richet, P., Bottinga, Y., Javoy, M., 1977. A Review of hydrogen, carbon, nitrogen, oxygen, sulphur, and chlorine stable isotope fractionation among gaseous molecules. Annu. Rev. Earth Planet. Sci. 5, 65-110.

Ryan, B.M., Kirby, J.K., Degryse, F., Scheiderich, K., McLaughlin, M.J., 2014. Copper isotope fractionation during equilibration with natural and synthetic ligands. Environ. Sci. Technol. 48, 8620-8626.

Salmanzadeh, M., Hartland, A., Stirling, C.H., Balks, M.R., Schipper, L.A., Joshi, C., George, E., 2017. Isotope tracing of long-term cadmium fluxes in an agricultural 
soil. Environ. Sci. Technol. 51, 7369-7377.

800

801

802

803

804

805

806

807

808

809

810

811

812

813

814

815

Satarug, S., Garrett, S.H., Sens, M.A., Sens, D.A., 2010. Cadmium, environmental exposure, and health outcomes. Environ. Health Perspect. 118, 182-190.

Schauble, E., Rossman, G.R., Taylor, H.P., 2004. Theoretical estimates of equilibrium chromium-isotope fractionations. Chem. Geol. 205, 99-114.

Schauble, E.A., 2007. Role of nuclear volume in driving equilibrium stable isotope fractionation of mercury, thallium, and other very heavy elements. Geochim. Cosmochim. Acta 71, 2170-2189.

Schauble, E. A., 2011. First-principles estimates of equilibrium magnesium isotope fractionation in silicate, oxide, carbonate and hexaaquamagnesium(2+) crystals. Geochim. Cosmochim. Acta 75(3), 844-869.

Schauble, E. A., Rossman, G.R., Taylor, H.P., 2003. Theoretical estimates of equilibrium chlorine-isotope fractionations. Geochim. Cosmochim. Acta 67, $3267-3281$.

Seth, C., Remans, T., Keunen, E., Jozefczak, M., Gielen, H., Opdenakker, K., Weyens, N., Vangronsveld, J., Cuypers, A., 2011. Phytoextraction of toxic metals: A central role for glutathione. Plant. Cell Environ. 35, 334-346.

Sieber, M., Conway, T.M., de Souza, G.F., Obata, H., Takano, S., Sohrin, Y., Vance, D., 2019. Physical and biogeochemical controls on the distribution of dissolved cadmium and its isotopes in the Southwest Pacific Ocean. Chem. Geol. 511, $494-509$.

Sigel, A., Sigel, H., Sigel, R.K. (Eds.), 2013. Cadmium: from toxicity to essentiality, 
822 Siddiqui, K.A., Mehrotra, G.K., Narvi, S.S., Butcher, R.J., 2011. Molecular selfsolvation models. Chem. Rev. 105, 2999-3094. 
Tsipis, A.C., 2014. DFT flavor of coordination chemistry. Coord. Chem. Rev. 272, 129.

Urey, H.C., 1947. The thermodynamic properties of isotopic substances. J. Chem. Soc. $562-581$.

Vogt, N., Haaland, A., Martinsen, K.-G., Vogt, J., Grenthe, I., Li, K., MIlanova, R., Nakata, H., Nasiri, A., Tsuda, T., 1993. Molecular parameters of gaseous CdCl2 from electron diffraction and vibrational Spectroscopic data. Acta Chem. Scand. 47, 937-939.

Wang, K. T., Sitsel, O., Meloni, G., Autzen, H., Andersson, M., Klymchuk, T., Nielsen, A., Rees, D., Nissen, P., Gourdon, P., 2014. Structure and mechanism of $\mathrm{Zn}^{2+}$-transporting P-type ATPases. Nature 514.

Wang, M.-J., Wang, W.-X., 2009. Cadmium in three marine phytoplankton: Accumulation, subcellular fate and thiol induction. Aquat. Toxicol. 95, 99-107.

Wasylenki, L.E., Swihart, J.W., Romaniello, S.J., 2014. Cadmium isotope fractionation during adsorption to Mn oxyhydroxide at low and high ionic strength. Geochim. Cosmochim. Acta 140, 212-226.

Weeks, C.L., Anbar, A.D., Wasylenki, L.E., Spiro, T.G., 2007. Density functional theory analysis of molybdenum isotope fractionation. J. Phys. Chem. A 111, $12434-12438$.

Wei, R., Guo, Q., Wen, H., Liu, C., Yang, J., Peters, M., Hu, J., Zhu, G., Zhang, H., Tian, L., Han, X., Ma, J., Zhu, C., Wan, Y., 2016. Fractionation of stable cadmium isotopes in the cadmium tolerant ricinus communis and 
Wiederhold, J.G., 2015. Metal stable isotope signatures as tracers in environmental geochemistry. Environ. Sci. Technol. 49, 2606-2624.

Wierzbicka, M.H., Przedpełska, E., Ruzik, R., Ouerdane, L., Połeć-Pawlak, K., Jarosz, M., Szpunar, J., Szakiel, A., 2007. Comparison of the toxicity and distribution of cadmium and lead in plant cells. Protoplasma 231, 99.

Wiggenhauser, M., Aucour, A.-M., Bureau, S., Campillo, S., Telouk, P., Romani, M., Ma, J.F., Landrot, G., Sarret, G., 2021. Cadmium transfer in contaminated soilrice systems: Insights from solid-state speciation analysis and stable isotope fractionation. Environ. Pollut. 269, 115934.

Wiggenhauser, M., Bigalke, M., Imseng, M., Müller, M., Keller, A., Murphy, K., Kreissig, K., Rehkämper, M., Wilcke, W., Frossard, E., 2016. Cadmium isotope fractionation in soil-wheat systems. Environ. Sci. Technol. 50, 9223-9231.

Wiggenhauser, M., Bigalke, M., Imseng, M., Keller, A., Archer, C., Wilcke, W.,Frossard, E., 2018. Zinc isotope fractionation during grain filling of wheat and a comparison of zinc and cadmium isotope ratios in identical soil-plant systems. New Phytol. 219, 195-205.

Wombacher, F., Rehkämper, M., 2004. Problems and suggestions concerning the notation of cadmium stable isotope compositions and the use of reference materials. Geostand. Geoanalytical Res. 28, 173-178.

Wu, Z., Zhang, C., Yan, J., Ge, Y., 2013. Separation and quantification of cysteine, glutathione and phytochelatins in rice (Oryza sativa L.) upon cadmium exposure 
using reverse phase ultra performance liquid chromatography (RP-UPLC) with fluorescence detection. Anal. Methods 5, 6147-6152.

Yang, J., Li, Y., Liu, S., Tian, H., Chen, C., Liu, J., Shi, Y., 2015. Theoretical calculations of Cd isotope fractionation in hydrothermal fluids. Chem. Geol. 391, $74-82$.

Yang, W.-J., Ding, K.-B., Zhang, P., Qiu, H., Cloquet, C., Wen, H.-J., Morel, J.-L., Qiu, R.-L., Tang, Y.-T., 2019. Cadmium stable isotope variation in a mountain area impacted by acid mine drainage. Sci. Total Environ. 646, 696-703.

Zeini Jahromi, E., Gailer, J., Pickering, I.J., George, G.N., 2014. Structural characterization of $\mathrm{Cd}^{2+}$ complexes in solution with DMSA and DMPS. J. Inorg. Biochem. 136, 99-106.

Zelano, I.O., Cloquet, C., Fraysse, F., Dong, S., Janot, N., Echevarria, G., MontargèsPelletier, E., 2018. The influence of organic complexation on $\mathrm{Ni}$ isotopic fractionation and Ni recycling in the upper soil layers. Chem. Geol. 483, 47-55.

Zhang, S.-N., Gu, Y., Zhu, Z.-L., Hu, S.-H., Kopittke, P.M., Zhao, F.-J., Wang, P., 2021. Stable isotope fractionation of cadmium in the soil-rice-human continuum. Sci. Total Environ. 761, 143262.

Zhang, Y., Wen, H., Zhu, C., Fan, H., Cloquet, C., 2018. Cadmium isotopic evidence for the evolution of marine primary productivity and the biological extinction event during the Permian-Triassic crisis from the Meishan section, South China. Chem. Geol. 481, 110-118.

Zhang, Y., Wen, H., Zhu, C., Fan, H., Luo, C., Liu, J., Cloquet, C., 2016. Cd isotope 
Zhao, C.-M., Campbell, P., Wilkinson, K., 2016. When are metal complexes bioavailable? Environ. Chem. 13, 425-433.

Zhou, J.-W., Li, Z., Liu, M.-S., Yu, H.-M., Wu, L.-H., Huang, F., Luo, Y.-M., Christie,

P., 2020. Cadmium Isotopic Fractionation in the Soil-Plant System during Repeated Phytoextraction with a Cadmium Hyperaccumulating Plant Species. Environ. Sci. Technol. 54, 13598-13609.

Zhu, C., Wen, H., Zhang, Y., Fan, H., Fu, S., Xu, J., Qin, T., 2013. Characteristics of Cd isotopic compositions and their genetic significance in the lead-zinc deposits of SW China. Sci. China Earth Sci. 56 (12), 2056-2065.

Zhu, C., Wen, H., Zhang, Y., Fan, H., 2016. Cadmium and sulfur isotopic compositions of the Tianbaoshan $\mathrm{Zn}-\mathrm{Pb}-\mathrm{Cd}$ deposit, Sichuan Province, China. Ore Geol. Rev. 76, 152-162.

Zhu, C., Wen, H., Zhang, Y., Yin, R., Cloquet, C., 2018. Cd isotope fractionation during sulfide mineral weathering in the Fule $\mathrm{Zn}-\mathrm{Pb}-\mathrm{Cd}$ deposit, Yunnan Province, Southwest China. Science of The Total Environment. 616-617, 64-72.

Zorrig, W., Rouached, A., Shahzad, Z., Abdelly, C., Davidian, J.-C., Berthomieu, P., 2010. Identification of three relationships linking cadmium accumulation to cadmium tolerance and zinc and citrate accumulation in lettuce. J. Plant Physiol. $167,1239-1247$. 
Fig. 1. Optimized molecular structures for various Cd species. a-b: Cd hydrate; c-f: Cd-citrate, the original source of the structure derives from Bertoli et al. (2015) and Fujii et al. (2012); g: CdEDTA (Kovács et al., 2010); h: Cd-histidine (Colaneri et al., 2013); i-j: Cd-DMPS (Zeini Jahromi et al., 2014); k: Cd-cysteine (Jalilehvand et al., 2009 and Fujii et al., 2014); 1: Cdglutathione (Delalande et al., 2010). Abbreviations are cit (citrate), EDTA (ethylenediaminetetraacetic acid), his (histidine), DMPS (dimercaptopropane sulfonic acid), cys (cysteine), and deprotonated glutathione (GSH) is shown as GS. Symbol keys: H (white), C (grey), N (blue), O (red), S (purple), Cd (yellow).

Fig. 2. Temperature dependence of $10^{3} \ln \left(\beta_{114-110}\right)$ for Cd hydrate, citrate, EDTA, histidine, DMPS, cysteine and glutathione complexes. X-axis shows the function of $10^{6} / \mathrm{T}^{2}$ (lower shaft) and corresponding temperature (upper shaft, $0-100 \square$ ), Y-axis shows the $10^{3} \ln \left(\beta_{114-110}\right)$ values.

Fig. 3. $\mathrm{Cd}\left({ }^{114} \mathrm{Cd} /{ }^{110} \mathrm{Cd}\right)$ isotopic variations with different donor atoms at $25^{\circ} \mathrm{C}$. The complexes complex is $\mathrm{Cd}(\mathrm{DMPS})_{2}{ }^{4-}$.

Fig. 4. Reduced partition function ratios, $10^{3} \ln \left(\beta_{114-110}\right)$ vs. mean bond length $(\AA)$ at $25^{\circ} \mathrm{C}$ Just as 
$954 \mathrm{Cd}(\mathrm{cys})\left(\mathrm{H}_{2} \mathrm{O}\right)_{3}{ }^{2+}$ and $\mathrm{Cd}(\mathrm{GS})_{2}\left(\mathrm{H}_{2} \mathrm{O}\right)_{2}{ }^{2-} ; \mathrm{S}$ donor complex as $\mathrm{O}$, is $\mathrm{Cd}(\mathrm{DMPS})_{2}{ }^{4-}$.

955 


\title{
Theoretical Isotope Fractionation of Cadmium during Complexation with Organic Ligands
}

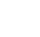

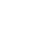

\author{
Yang Zhao a, Yongbing Li ${ }^{\mathrm{b}, *}$, Matthias Wiggenhauser ${ }^{\mathrm{c}, \mathrm{d}, *}$, Junli Yang ${ }^{\mathrm{a}}$, \\ Géraldine Sarret ${ }^{c}$, Qi Cheng ${ }^{\text {a }}$, Jianming Liu ${ }^{\mathrm{a}, \mathrm{e}}$, Yaolin Shi ${ }^{\mathrm{b}}$
}

${ }^{a}$ College of Earth and Planetary Sciences, University of Chinese Academy of Sciences, Beijing 100049, China

${ }^{b}$ Key Laboratory of Computational Geodynamics, Chinese Academy of Sciences, University of Chinese Academy of

Sciences, Beijing 100049, China

'ISTerre, Univ. Grenoble Alpes, Univ. Savoie Mont Blanc, CNRS, IRD, IFSTTAR, Grenoble, France

dInstitute of Agricultural Sciences, ETH Zurich, Eschikon 33, CH-8315 Lindau, Switzerland

${ }^{e}$ Key Laboratory of Mineral Resources, Institute of Geology and Geophysics, Chinese Academy of Sciences,

Beijing 100029, China

*Corresponding authors:

Yongbing Li

No. 19A, Yuquan Road, Shijingshan District, Beijing 100049, PR China.

Tel.: +86 1088256476 .

E-mail address: yongbingli@ucas.ac.cn (Y. Li)

Matthias Wiggenhauser

Institute of Agricultural Sciences, ETH Zurich, Eschikon 33, CH-8315 Lindau, Switzerland

Tel.: +41523549216

E-mail address: matthias.wiggenhauser@usys.ethz.ch (M. W) 
Abstract: Cadmium (Cd) isotopes are an important tool to better understand both inorganic and organic geochemistry of $\mathrm{Cd}$, and organic ligands play a key role to control the toxicity and mobility of $\mathrm{Cd}$ in living organisms and also in terrestrial and aquatic environments. Knowledge of the equilibrium isotope fractionation of $\mathrm{Cd}$ with organic ligands is crucial to further advance $\mathrm{Cd}$ isotope source and process tracing in the field of biogeochemistry. In this study, we calculated reduced partition function ratios $\left(10^{3} \ln \beta\right)$ of $\mathrm{Cd}$ isotopes in various organic $\mathrm{Cd}$ complexes by density functional theory. The calculation results show that the $10^{3} \ln \beta$ of ${ }^{114} \mathrm{Cd} /{ }^{110} \mathrm{Cd}$ for these complexes are decreased in the order of $\mathrm{Cd}(\mathrm{Hcit})\left(\mathrm{H}_{2} \text { cit }\right)^{-}>\mathrm{Cd}(\mathrm{cit})\left(\mathrm{H}_{2} \mathrm{O}\right)_{3}{ }^{-}>$ $\mathrm{CdH}(\mathrm{cit})\left(\mathrm{H}_{2} \mathrm{O}\right)_{4}>\mathrm{CdEDTA}>\mathrm{Cd}(\text { his })_{2} \mathrm{H}_{2} \mathrm{O}>\mathrm{Cd}(\mathrm{cit})_{2}{ }^{4-} \approx \mathrm{Cd}\left(\mathrm{H}_{2} \mathrm{O}\right)_{6}{ }^{2+}>\mathrm{Cd}\left(\mathrm{H}_{2} \mathrm{O}\right)_{4}{ }^{2+}>$ $\mathrm{Cd}($ cys $)\left(\mathrm{H}_{2} \mathrm{O}\right)_{3}{ }^{2+}>\mathrm{Cd}(\mathrm{GS})_{2}\left(\mathrm{H}_{2} \mathrm{O}\right)_{2}{ }^{2-}>\mathrm{Cd}(\mathrm{DMPS})\left(\mathrm{H}_{2} \mathrm{O}\right)_{2}{ }^{-}>\mathrm{Cd}(\mathrm{DMPS})_{2}{ }^{4-}$ at 0 $100^{\circ} \mathrm{C}$, and heavy $\mathrm{Cd}$ isotopes preferably bind to oxygen and nitrogen donor atoms while light $\mathrm{Cd}$ isotopes bind to sulfur donor atoms of organic ligands. Thus, the previously observed immobilization of light $\mathrm{Cd}$ isotopes in living organisms could be related to $\mathrm{Cd}$ detoxification processes with sulfur. The predicted equilibrium isotope fractionation will strengthen $\mathrm{Cd}$ isotopes as a process tracing tool in these systems and will improve the understanding of $\mathrm{Cd}$ isotope cycling in aquatic and terrestrial systems.

Keywords: Cd isotope; Organic complexes; Equilibrium isotope fractionation; O/N/S donor; Destiny functional theory; Isotope biogeochemistry 


\section{Introduction}

Cadmium $(\mathrm{Cd})$ is a non-essential element for most living organisms (Sigel et al., 2013). It is ubiquitous in terrestrial and aquatic environments where it can occur naturally or through anthropogenic activities (Kabata-Pendias, 2011; Liu et al., 2017). Being very mobile, it is readily taken up by living organisms (Khan et al., 2014; Thévenod et al., 2019), where it can impair the organisms itself (Sigel et al., 2013) and/or it can be further transported along the food chain and accumulated in animals and humans (Fransson et al., 2014; Satarug et al., 2010). Thus, the understanding of processes that control the fate of $\mathrm{Cd}$ in the terrestrial and aquatic environments are crucial.

Isotope geochemistry has been increasingly applied in the past years for tracing anthropogenic Cd pollution (Cloquet et al., 2006; Salmanzadeh et al., 2017; Imseng et al., 2018; Yang et al., 2019), tracing the source of ore-forming fluids (Zhu et al., 2016), to advance the understanding of the past and present marine biogeochemical cycling of Cd (Lambelet et al., 2013; Zhang et al., 2018; Sieber et al., 2019), as well as to trace processes that control the $\mathrm{Cd}$ homeostasis in unicell organisms (Horner et al., 2013; Moore et al., 2020) and distinct types of plants such as grasses (Wiggenhauser et al., 2016; Imseng et al., 2018; Wiggenhauser et al., 2021; Zhang et al., 2021), cacao (Barraza et al., 2019; Moore et al., 2020), and Cd accumulating plants (Wei et al., 2016; Zhou et al., 2020). Cd has eight stable isotopes which atomic masses range from 106-116, their ratios can vary significantly in the environment 
(Hoefs, 2015). Cd isotope fractionation in terrestrial and aquatic systems is generated by multiple processes such as sorption to reactive surfaces (Wasylenki et al., 2014), precipitation of Cd into minerals (e.g., calcite, Horner et al., 2011; Guinoiseau et al., 2018; sphalerite, Zhu et al., 2013), membrane transport (Wei et al., 2016), weathering (Zhang et al., 2016; Zhu et al., 2018), binding to inorganic materials (Wasylenki et al., 2014; Yang et al., 2015; Guinoiseau et al., 2018), and complexation with organic ligands as shown for other metals (Morgan et al., 2010; Ryan et al., 2014; Marković et al., 2017). Once isotope fractionation factors are defined for these processes, $\mathrm{Cd}$ isotopes can provide novel information about major biogeochemical processes that control the mobility of $\mathrm{Cd}$ in complex terrestrial and aquatic systems. For $\mathrm{Cd}$, binding to organic ligands plays a crucial role in detoxifying, sequestrating and separating toxic Cd from essential nutrients in living organisms (Wang and Wang, 2009; Cao et al., 2018; Le Croizier et al., 2019). Recent studies showed that Cd isotopes are strongly fractionated in living organisms which has been attributed to processes such as membrane transport (Moore et al., 2020) and Cd binding to organic ligands (Wiggenhauser et al., 2016, 2018, 2021). For the latter, it was hypothesized that Cd binding to reduced sulfur groups (R-SH, thiols) in the bacteria E.coli to detoxify $\mathrm{Cd}$ resulted in an enrichment of light isotope in membranes (Horner et al., 2013). Furthermore, cereals strongly retained light $\mathrm{Cd}$ isotopes in roots which lead to an enrichment of heavy isotopes in shoots and grains (Wiggenhauser et al., 2016; Imseng et al., 2019; Wiggenhauser et al., 2021; Zhang et al., 2021). The immobilization of light isotopes was ascribed to binding of $\mathrm{Cd}$ to thiols to detoxify and sequestrate $\mathrm{Cd}$ in 
roots and shoot parts and to avoid accumulation of $\mathrm{Cd}$ in grains (Wiggenhauser et al., 2016). Together, studies in living organisms proposed that sulfur (S) involved detoxification and immobilization processes of $\mathrm{Cd}$ could be a major driver of $\mathrm{Cd}$ isotope fractionation. However, no isotope fractionation factor for $\mathrm{Cd}$ binding to distinct organic ligands exist yet, which makes it difficult to interpret $\mathrm{Cd}$ isotope fractionation in complex biological systems.

During the past few years, calculating isotope fractionation for distinct metal complexes has significantly improved metal isotope process tracing applications in complex biogeochemical systems (Fujii and Albarède, 2012; Moynier et al., 2013; Fujii et al., 2014; Wiederhold, 2015; Albarede et al., 2016; Moynier and Fujii, 2017). For inorganic $\mathrm{Cd}$ complexes, theoretical calculations predicted that $\mathrm{Cd}$ hydroxides and $\mathrm{Cd}$ nitrates are isotopically heavier compared to hydrated $\mathrm{Cd}$ while hydrated $\mathrm{Cd}$ is heavier than Cd chlorides and hydrosulfide (Yang et al., 2015). Guinoiseau et al. (2018) recently verified these in a Cd sulfide precipitation experiment which revealed that $\mathrm{Cd}$ light isotope was enriched in sulfide and that the enrichment of light isotope decreased with increasing chloride concentration in solution. For organic ligands, either experimental or theoretical $\mathrm{Cd}$ isotope fractionation data of $\mathrm{Cd}$ organic complexes has not been studied. Such $\mathrm{Cd}$ isotope fractionation data would be particularly useful to improve $\mathrm{Cd}$ isotope process in tracing complex biogeochemical systems where organic ligands play a crucial role on the fate of $\mathrm{Cd}$ in the environment. Here, we aimed to strengthen $\mathrm{Cd}$ isotope process tracing approaches by applying density functional theory (DFT) to calculate $\mathrm{Cd}$ hydrated complexes 
$117 \mathrm{Cd}\left(\mathrm{H}_{2} \mathrm{O}\right)_{4}{ }^{2+}$ and $\mathrm{Cd}\left(\mathrm{H}_{2} \mathrm{O}\right)_{6}{ }^{2+} ;$ Cd-citrate complexes $\mathrm{Cd}(\mathrm{cit})_{2}{ }^{4-}, \mathrm{Cd}(\mathrm{Hcit})\left(\mathrm{H}_{2} \mathrm{cit}\right)^{-}$, $118 \mathrm{CdH}($ cit $)\left(\mathrm{H}_{2} \mathrm{O}\right)_{4}$ and $\mathrm{Cd}(\mathrm{cit})\left(\mathrm{H}_{2} \mathrm{O}\right)_{3}{ }^{-}$; CdEDTA; Cd-histidine Cd(his $)_{2} \mathrm{H}_{2} \mathrm{O}$; Cd-DMPS 119 complexes Cd(DMPS $)_{2}{ }^{4-}$ and $\mathrm{Cd}(\mathrm{DMPS})\left(\mathrm{H}_{2} \mathrm{O}\right)_{2}{ }^{-} ; \mathrm{Cd}$-cysteine $\mathrm{Cd}(\mathrm{cys})\left(\mathrm{H}_{2} \mathrm{O}\right)_{3}{ }^{2+} ; \mathrm{Cd}-$ 120 glutathione complex $\mathrm{Cd}(\mathrm{GS})_{2}\left(\mathrm{H}_{2} \mathrm{O}\right)_{2}{ }^{2-}$. The obtained results were discussed regarding 121 its implications for past and future $\mathrm{Cd}$ isotope processes tracing approaches.

\section{Theory and methods}

\subsection{Cd organic complexes}

Oxygen $(\mathrm{O})$, nitrogen $(\mathrm{N})$, and sulfur $(\mathrm{S})$ are abundant elements that essential for all living organisms. In organic ligands, they serve as donor atoms to bind metals such as Cd as part of organic complexes such as citrate (cit) (McLean et al., 2013; Panfili et al., 2009; Zorrig et al., 2010), histidine (his) (Wierzbicka et al., 2007; Gunawardana et compounds for strong chelating complexes. EDTA represents chelators with $\mathrm{O}$ and $\mathrm{N}$ 
Puschenreiter et al., 2017) and DMPS represents strong chelators with S donors such as phytochelatin (Marentes and Rauser, 2007; Pal et al., 2019).

\subsection{Calculations}

Equilibrium isotope exchange reaction between two metal complexes can be represented by:

$$
A Y+B Y^{*}=A Y^{*}+B Y
$$

where $Y$ denotes one element that is represented by light $(Y)$ and heavy isotopes $\left(Y^{*}\right)$. $A$ and $B$ represent two different ligands. Ligands and isotopes of $Y$ form the chemical complexes $A Y$ and $B Y$. The isotope fractionation factor $\alpha$ between the complexes $A Y$ and $B Y$ is defined as:

$$
\alpha_{\mathrm{AY}-\mathrm{BY}}=\mathrm{K}_{\mathrm{eq}}=\frac{\beta_{\mathrm{AY}}}{\beta_{\mathrm{BY}}}
$$

the isotope fractionation factor is expressed in permill [\%o]:

$$
10^{3} \ln \alpha_{\mathrm{AY}-\mathrm{BY}}=10^{3} \ln \beta_{\mathrm{AY}}-10^{3} \ln \beta_{\mathrm{BY}}
$$

In these equations, $K$ is the equilibrium constant, which is equal to the $\alpha$ of the isotope exchange reaction of chemical complexes $(A Y, B Y)$ that exchange the same element $(Y) . \beta$ is the reduced partition function ratio (RPFR). Bigeleisen and Mayer (1947) and Urey (1947) suggested that equilibrium mass-dependent isotope fractionation factors results from the molecular vibrational frequencies. $\beta$ can be calculated as:

$$
\beta_{114-110}=\prod_{i}{ }_{i 110} U_{i} U_{i} \frac{e^{-114} U_{i} / 2}{e^{-110} U_{i} / 2} \frac{1-e^{-110} U_{i}}{1-e^{-114} U_{i}}
$$


$U_{i}$ and $v_{i}$ are defined as:

$$
U_{i}=h v_{i} / k T
$$

Here, $h, k$, and $T$ refer to the Planck's constant, Boltzmann constant and absolute temperature, respectively. $v_{i}$ is the harmonic vibrational frequency of the $i$ th vibrational mode in $s^{-1}$. The number of vibrational modes for non-linear molecules is $3 n-6$ ( $n$ is the number of atoms in the molecule), $3 n-5$ for linear molecules.

In this study ${ }^{114} \mathrm{Cd} /{ }^{110} \mathrm{Cd}$ isotope ratios were chosen to study the $\mathrm{Cd}$ isotope fractionation of $\mathrm{Cd}$ partitioning into different chemical complexes. The ${ }^{114} \mathrm{Cd} /{ }^{110} \mathrm{Cd}$ is a widely used isotope ratio in experimental (Rehkämper et al., 2011; Horner et al., 2013; Pallavicini et al., 2014; Chrastný et al., 2015; Wei et al., 2016; Li et al., 2018) and theoretical studies (Yang et al., 2015). Gaussian 09 (Dennington et al., 2009; Frisch et al., 2009) was used to calculate the geometries optimization and vibrational frequencies of $\mathrm{Cd}$ species using Becke-style 3-parameter (B3) density functional theory with the Lee-Yang-Parr (LYP) correlation functional (Lee et al., 1988; Becke, 1993a, b). In this study, the mixed basis sets were used, for H, C, N, O, and S, the allelectron basis set 6-311+G(d, p) was used (Clark et al., 1983; Francl et al., 1982; Krishnan et al., 1980; McLean and Chandler, 1980; Spitznagel et al., 1987); for Cd, an effective-core potential (ECP) basis set LanL2DZ was chosen (Hay and Wadt, 1985). The "ultrafine" numerical integration grid was used and the molecular geometries were optimized without any forced symmetry for all complexes. The setting of exchange correlation functionals may have effect on the calculated vibrational frequencies, and four exchange correlation functionals B3LYP, BVP86, 
183

184

185

186

187

188

189

190

191

192

193

194

195

196

197

198

199

200

201

202

203

204

B3PW91 and PBEPBE were tested. For Cd(Hcit) $\left(\mathrm{H}_{2} \mathrm{cit}\right)^{-}$, the mean square errors of the calculated vibrational frequencies of the four exchange correlation functionals are 366.90, 874.94, 1084.19 and 7440.05 respectively (Table S1), the calculated frequencies by B3LYP are more consistent with the experimental results and the B3LYP functional was chosen to estimate the isotope fractionation of $\mathrm{Cd}$ complexes in this study.

\section{Results and discussion}

\subsection{Optimized molecular geometries}

The optimized geometries of the organic Cd complexes are shown in Fig. 1. For comparison, Table 1 lists the optimized bond lengths calculated by this study, and previously published theoretical and experimental data. Donor atoms, optimized coordinated bond lengths $(\AA)$ and mean bond lengths $(\AA)$ are shown in Table S3 (Supplementary material). The optimized Cd-O distances of $\mathrm{Cd}\left(\mathrm{H}_{2} \mathrm{O}\right)_{4}{ }^{2+}$ and $\mathrm{Cd}\left(\mathrm{H}_{2} \mathrm{O}\right){ }_{6}{ }^{2+}$ (Fig. 1a, b) by using the basis set $6-311+\mathrm{G}(\mathrm{d}, \mathrm{p})$ are consistent with those by using the basis set 6-31+G(d, p) (Yang et al., 2015).

For Cd-citrate complexes: $\mathrm{Cd}(\mathrm{cit})_{2}{ }^{4-}, \mathrm{Cd}(\mathrm{Hcit})\left(\mathrm{H}_{2} \mathrm{cit}\right)^{-}, \mathrm{CdH}(\mathrm{cit})\left(\mathrm{H}_{2} \mathrm{O}\right)_{4}$ and $\mathrm{Cd}(\mathrm{cit})\left(\mathrm{H}_{2} \mathrm{O}\right)_{3}{ }_{3}^{-}$, the deprotonated carboxyl groups in $\mathrm{Cit}^{3-}$ are always coordinated to the central $\mathrm{Cd}^{2+}$ (Bertoli et al., 2015). The $\mathrm{d} 10$ electron configuration of $\mathrm{Cd}^{2+}$ favors sixfold coordination and forms octahedral geometry (Siddiqui et al., 2011), while in 
205

206

207

208

209

210

211

212

213

214

215

216

217

218

219

220

221

222

223

224

225

226

less bulky ligands, $\mathrm{Cd}^{2+}$ tends to form tetrahedral coordination complexes (Ramalho and Figueroa-Villar, 2002; Bertoli et al., 2015). Cd(cit) $2^{4-}$ (Fig. 1c) and $\mathrm{Cd}(\mathrm{Hcit})\left(\mathrm{H}_{2} \text { cit) }\right)^{-}$(Fig. 1d) with fourfold coordination complexes, are adducts of two citrate molecules and have several isomers in solution (Bertoli et al., 2015). They differ in their protonation and each of the two citrate molecules provided two carboxylate oxygen atoms to coordinate to $\mathrm{Cd}^{2+}$. The coordinated bond lengths of $\mathrm{Cd}(\mathrm{cit})_{2}{ }^{4-}$ and $\mathrm{Cd}(\mathrm{Hcit})\left(\mathrm{H}_{2} \mathrm{cit}\right)^{-}$were $2.21,2.22 \AA$ and $2.14-2.38 \AA$ respectively. The $\mathrm{Cd}$ atoms in $\mathrm{CdH}(\mathrm{cit})\left(\mathrm{H}_{2} \mathrm{O}\right)_{4}$ (Fig. 1e) and $\mathrm{Cd}(\mathrm{cit})\left(\mathrm{H}_{2} \mathrm{O}\right)_{3}{ }^{-}$(Fig. 1f) were sixfold coordinated, their bond lengths were 2.24-2.40 $\AA$ and 2.24-2.43 $\AA$, respectively.

CdEDTA (Fig. 1g) is sixfold coordinated, and EDTA provides two $\mathrm{N}$ and four $\mathrm{O}$ donor atoms for $\mathrm{Cd}^{2+}$. The stronger binding of $\mathrm{Cd}^{2+}$ to $\mathrm{N}$ than to $\mathrm{O}$, and the electrostatic attraction induced by the carboxylate result in a high stability for CdEDTA (Kovács et al., 2010; Karak et al., 2016). The calculated Cd-O and Cd-N distances (Cd-O: 2.26, 2.36; Cd-N: 2.48, Table 1b) in this study were close to those calculated by Kovács et al. (2010). Cd-histidine (Cd(his) ${ }_{2} \mathrm{H}_{2} \mathrm{O}$, Fig. 1h) is also sixfold coordinated and contains an imidazole ring, carboxyl and amino groups that provide four $\mathrm{N}$ and two $\mathrm{O}$ donor atoms for $\mathrm{Cd}^{2+}$ (Colaneri et al., 2013). The calculated distances were 2.26 ̊̊ for Cd-O 2.41-2.48 $\AA$ for Cd-N (Table 1b).

The ligand DMPS contains two thiolate groups and one sulfonate group, and the thiol groups of the DMPS chelate $\mathrm{Cd}^{2+}$ in fourfold coordination (Zeini Jahromi et al., 2014, Fig. 1i and 1j). For 1:1 Cd-DMPS complexes, the calculated average distance of Cd to its $\mathrm{S}$ donor atoms was $2.48 \AA$. For 1:2 Cd-DMPS complexes, the average bond 
distance to four $\mathrm{S}$ donor atoms was $2.69 \AA$. The calculated bond lengths were consistent with the previously published values (Table 1b) (Zeini Jahromi et al., 2014).

For $\mathrm{Cd}($ cys $)\left(\mathrm{H}_{2} \mathrm{O}\right)_{3}{ }^{2+}$ (Fig. 1k), the thiol group of cysteine tends to bind the metal ion by $\mathrm{S}$ donor atoms when cysteine is present in excess (Jalilehvand et al., 2009; Fujii et al., 2014). In our study, Cd was bound to three water molecules and one thiol group of cysteine, the bond length of $\mathrm{Cd}$ to its $\mathrm{S}$ donor atoms was $2.48 \AA$, which was slightly shorter than the experimental data of Cd-cysteine 2.52-2.54 $\AA$ (Jalilehvand et al., 2009). Glutathione, $\gamma$-Glu-Cys-Gly, is a thiol-containing tripeptide, and the ligands of 1:2 Cd-glutathione complexes (Fig. 11) are $\mathrm{GS}^{3-}$ molecules with amide protons, where $\mathrm{Cd}$ has a tetrahedral coordination sphere and the complex primarily involves two deprotonated thiol groups from cysteine residues and two water molecules (Delalande et al., 2010). EXAFS spectra of Cd-glutathione complexes suggested $\mathrm{Cd}$ was fourfold coordination and $\mathrm{S}$ atoms were identified as the binding atoms at $2.54 \pm 0.1 \AA$ (Isaure et al., 2015). The calculated Cd-S mean bond distance in

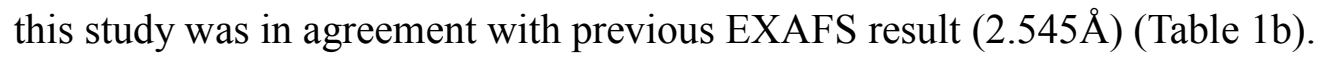

\subsection{Comparison with experimental vibrational frequencies}

Only a few experimentally determined vibrational frequencies exist for organic $\mathrm{Cd}$ complexes since they are difficult to determine experimentally. Richet et al. (1977) thought the effects of anharmonicity on the isotope fractionation are expected to be 
quite small, here only harmonic vibration was considered. Table 2 lists the calculated harmonic vibrational frequencies of the ${ }^{114} w$ isotopomer and ${ }^{110} w$ isotopomer of $\mathrm{Cd}(\mathrm{Hcit})\left(\mathrm{H}_{2} \mathrm{cit}\right)^{-}$and the experimental data by FTIR (Bertoli et al., 2015). The frequency shifts values $10^{3}\left(1-{ }^{114} w /{ }^{110} w\right)$ of $\mathrm{Cd}$ isotopes are also listed.

In Table $2, w_{1}$ is the twisting vibration mode of $\mathrm{H}-\mathrm{C}-\mathrm{H}$ with stretching vibration mode of C-O, the experimental vibrational frequencies by Bertoli et al. (2015) was $1027.05 \mathrm{~cm}^{-1}$, the calculated data by this study were $1041.1681 \mathrm{~cm}^{-1}$ for ${ }^{114} w$ isotopomer and $1041.1686 \mathrm{~cm}^{-1}$ for ${ }^{110} w$ isotopomer, the average value of the calculated frequency of the two isotopomers is about $1.375 \%$ higher than experimental data. $w_{2}$ is the rocking vibration mode of $\mathrm{H}-\mathrm{C}-\mathrm{H}$ with stretching vibration mode of $\mathrm{C}-\mathrm{C}$, the experimental data was $1078.98 \mathrm{~cm}^{-1}$, the calculated frequencies were $1079.978 \mathrm{~cm}^{-1}$ for $\mathrm{Cd}$ heavy isotope and $1079.9783 \mathrm{~cm}^{-1}$ for the light one, the average frequency values by this calculation is $0.093 \%$ higher than experimental data. $w_{3}$ is the twisting vibration mode of $\mathrm{H}-\mathrm{C}-\mathrm{H}$ with stretching vibration mode of $\mathrm{C}-\mathrm{C}$, the calculated average data is $1.041 \%$ lower than experimental data. $w_{4}$ is the scissoring vibration mode of $\mathrm{H}-\mathrm{C}-\mathrm{H}$, the average data by calculation is close to the experimental data and the calculated average frequency is $0.490 \%$ lower than experimental data. $w_{5}$ is the rocking vibration mode of $\mathrm{H}-\mathrm{C}-\mathrm{H}$ with stretching vibration mode of $\mathrm{C}-\mathrm{C}$ and $\mathrm{C}-\mathrm{O}$, the average data by calculation is $0.698 \%$ higher than experimental data. $w_{6}$ is the wagging vibration mode of $\mathrm{H}-\mathrm{C}-\mathrm{H}$ with scissoring vibration mode of $\mathrm{O}-\mathrm{H}$, the frequency difference between experiment and the average theory calculation is $0.142 \%$. The $w_{7}$ is the symmetrical stretching vibration and the 
271 difference between calculation and experiment is $0.310 \%$. $w_{8}$ is the symmetrical 272 stretching vibration mode of $\mathrm{COO}^{-}$, the difference of calculated data and experimental 273 data is $0.069 \%$. $w_{9}$ is asymmetrical stretching vibration of $\mathrm{COO}^{-}$, the average 274 frequency calculated is $3.187 \%$ higher than experimental results. For $w_{10}$, it is 275 stretching vibration mode and the calculated result is $0.652 \%$ lower than experimental 276 data (Table 2). Overall, the calculated frequencies were generally consistent with 277 previously experimental data of $\mathrm{Cd}(\mathrm{Hcit})\left(\mathrm{H}_{2} \mathrm{cit}\right)^{-}$.

278 The accuracy of vibrational frequencies can be further propagated in the final $27910^{3} \ln \beta$ values (Schauble et al., 2003, 2004; Schauble et al., 2007). Frequency scaling 280 factors can often be used to correct the calculated vibrational frequencies which are 281 able to reproduce the experimental frequencies. However, the simple harmonic 282 frequency calculated by quantum chemistry methods need to be corrected when it is 283 used to calculate isotope fractionation involving larger molecules (Liu et al., 2010; 284 Fujii et al., 2014). Here frequency scaling factors were not needed in this study.

\subsection{Reduced partition function ratios, $10^{3} \ln \left(\beta_{114-110}\right)$ for $C d$ complexes}

$\mathrm{Cd}$ species have been studied. The calculated reduced partition function ratios 
293

294

295

calculated in this study are reported in Table $3 .{ }^{114} \mathrm{Cd}$ and ${ }^{110} \mathrm{Cd}$ have the largest mass difference among Cd isotopes (Carignan et al., 2004; Wombacher and Rehkämper, 2004), usually ${ }^{114} \mathrm{Cd} /{ }^{110} \mathrm{Cd}$ isotope ratios were chosen to study the $\mathrm{Cd}$ isotope fractionation of $\mathrm{Cd}$ partitioning into different chemical complexes. Mass-dependent isotope fractionation is a function of temperature $(T)$, and can be expressed as below:

$$
10^{3} \ln \left(\beta_{114-110}\right)=A \times \frac{10^{6}}{T^{2}}+B
$$

Where $A, B$ are the regression parameters, which can be figured out from Table 3 . The A, B values of these complexes are listed in Table S2, for comparison their relationship also be figured in Fig. 2. Our calculation shows that the $10^{3} \ln \beta$ of ${ }^{114} \mathrm{Cd} /{ }^{110} \mathrm{Cd}$ for these complexes decreases in the order of $\mathrm{Cd}(\mathrm{Hcit})\left(\mathrm{H}_{2} \mathrm{cit}\right)^{-}>$ $\mathrm{Cd}(\mathrm{cit})\left(\mathrm{H}_{2} \mathrm{O}\right)_{3}{ }^{-}>\mathrm{CdH}(\mathrm{cit})\left(\mathrm{H}_{2} \mathrm{O}\right)_{4}>\mathrm{CdEDTA}>\mathrm{Cd}(\text { his })_{2} \mathrm{H}_{2} \mathrm{O}>\mathrm{Cd}(\mathrm{cit})_{2}{ }^{4-} \approx$ $\mathrm{Cd}\left(\mathrm{H}_{2} \mathrm{O}\right)_{6}{ }^{2+}>\mathrm{Cd}\left(\mathrm{H}_{2} \mathrm{O}\right)_{4}{ }^{2+}>\mathrm{Cd}(\mathrm{cys})\left(\mathrm{H}_{2} \mathrm{O}\right)_{3}{ }^{2+}>\mathrm{Cd}(\mathrm{GS})_{2}\left(\mathrm{H}_{2} \mathrm{O}\right)_{2}{ }^{2-}>\mathrm{Cd}(\mathrm{DMPS})\left(\mathrm{H}_{2} \mathrm{O}\right)_{2}{ }^{-}$ $>\mathrm{Cd}(\mathrm{DMPS})_{2}{ }^{4-}$ at $0 \sim 100^{\circ} \mathrm{C}$

Previous studies demonstrated that the types of donor atoms $(\mathrm{O}, \mathrm{N}, \mathrm{S})$ of organic ligands are a main driver for $\mathrm{Zn}$ isotope fractionation (Albarède et al., 2011; Fujii and Albarède, 2012; Balter et al., 2013; Moynier et al., 2013; Fujii et al., 2014). Particularly, $\mathrm{O}$ donors preferentially bind heavier $\mathrm{Zn}$ isotopes than $\mathrm{S}$ donors. $\mathrm{Cd}$ and $\mathrm{Zn}$ are in the same group in the periodic table which means that the two elements have the same number of electrons in their outer valence shell. Thus, the elements share similar chemical properties such as a flexible coordination chemistry, they are nonredox sensitive, and have similar stability constants (John et al., 2017; Maret and Moulis, 2013; Sóvágó and Várnagy, 2013). It is likely that O, N, and S donor atoms 
may have a similar effect on $\mathrm{Cd}$ isotope fractionation as they do for $\mathrm{Zn}$. This hypothesis has been recently partly verified by Yang et al. (2015) who reported an enrichment of heavy $\mathrm{Cd}$ isotopes for $\mathrm{O}$ and $\mathrm{N}$ compared to $\mathrm{S}$ donors of inorganic ligands. In addition, studies on $\mathrm{Zn}$ isotopes have shown that the number of coordination for the same donor atoms can also determine isotope fractionation (Fujii et al., 2014). For instance, fourfold coordinated Zn-amino acid complexes had larger $10^{3} \ln \left(\beta_{114-110}\right)$ values than the sixfold coordinated complexes of the same amino acid. The relationship between the $10^{3} \ln \left(\beta_{114-110}\right)$ values and donor atoms type of the $\mathrm{Cd}$ complexes at $25^{\circ} \mathrm{C}$ is given in Fig. 3 (the types and numbers of donor atoms are given in Table $\mathrm{S} 3$ ). For Cd complexes, $\mathrm{S}$ or combinations of $\mathrm{S}$ and $\mathrm{O}$ donor atoms tended to complex with lighter $\mathrm{Cd}$ isotopes. Furthermore, the $10^{3} \ln \left(\beta_{114-110}\right)$ disparities induced by $\mathrm{S}$ and $\mathrm{S} / \mathrm{O}$ donor atoms were bigger than those by $\mathrm{O}$ and $\mathrm{O} / \mathrm{N}$ donor atoms. The relationship between $10^{3} \ln \left(\beta_{114-110}\right)$ and mean bond lengths of $\mathrm{Cd}$ to its donor atoms at $25^{\circ} \mathrm{C}$ was shown in Fig. 4. Overall, mean coordinated bond lengths of complexes with O donor atoms were shorter than those with $\mathrm{S}$ donor atoms, except $\mathrm{Cd}(\mathrm{cys})\left(\mathrm{H}_{2} \mathrm{O}\right)_{3}{ }^{2+}$. The reason may be that $\mathrm{Cd}(\mathrm{cys})\left(\mathrm{H}_{2} \mathrm{O}\right)_{3}{ }^{2+}$ has three $\mathrm{O}$ donors and one $\mathrm{S}$ donor.

Among all studied $\mathrm{Cd}$ complexes, $\mathrm{Cd}(\mathrm{Hcit})\left(\mathrm{H}_{2} \text { cit }\right)^{-}$has the largest $10^{3} \ln \left(\beta_{114-110}\right)$ values while $\mathrm{Cd}(\mathrm{DMPS}){ }_{2}{ }^{4-}$ has the smallest $10^{3} \ln \left(\beta_{114-110}\right)$ values (Fig. 2 and Table 3 ), their difference can reach 1.18 at $25^{\circ} \mathrm{C}$. Cd-citrate complexes can be fourfold coordinated $\left(\mathrm{Cd}(\mathrm{Hcit})\left(\mathrm{H}_{2} \mathrm{cit}\right)^{-}\right.$and $\left.\mathrm{Cd}(\mathrm{cit})_{2}{ }^{4-}\right)$ and sixfold coordinated $\left(\mathrm{CdH}(\mathrm{cit})\left(\mathrm{H}_{2} \mathrm{O}\right)_{4}\right.$ and $\left.\mathrm{Cd}(\mathrm{cit})\left(\mathrm{H}_{2} \mathrm{O}\right)_{3^{-}}\right)$, and their $10^{3} \ln \left(\beta_{114-110}\right)$ values can differ up to 0.213 at $25^{\circ} \mathrm{C}$ which means that the structure difference of these Cd-citrate complexes can result in 
337 Cd isotope fractionation (Fig. 1, 2). In addition, $10^{3} \ln \left(\beta_{114-110}\right)$ values of fourfold 338 coordinated $\mathrm{Cd}(\mathrm{Hcit})\left(\mathrm{H}_{2} \mathrm{cit}\right)^{-}$were larger than those of sixfold coordinated $339 \mathrm{CdH}(\mathrm{cit})\left(\mathrm{H}_{2} \mathrm{O}\right)_{4}$ and $\mathrm{Cd}(\mathrm{cit})\left(\mathrm{H}_{2} \mathrm{O}\right)_{3}{ }^{-}$, but those of $\mathrm{Cd}(\mathrm{cit})_{2}{ }^{4-}$ are smaller than those of $340 \mathrm{CdH}(\mathrm{cit})\left(\mathrm{H}_{2} \mathrm{O}\right)_{4}$ and $\mathrm{Cd}(\mathrm{cit})\left(\mathrm{H}_{2} \mathrm{O}\right)_{3}{ }^{-}$. Thus, for Cd-citrate complexes, the coordination 341 number is only one of the factors that have an effect on $\mathrm{Cd}$ isotope fractionation, 342 when estimating Cd isotope fractionation of them, other factors should be considered. 343 The Cd-cysteine, Cd-GSH, and Cd-DMPS complexes contain S donor atoms. Our 344 calculations revealed that these $C d$ complexes had lower $10^{3} \ln \left(\beta_{114-110}\right)$ values in 345 comparison with hydrated $\mathrm{Cd}$ complexes and organic $\mathrm{Cd}$ complexes that contained $\mathrm{O}$ 346 and $\mathrm{N}$ donor atoms (Table 3 and Fig. 3). The lower $10^{3} \ln \left(\beta_{114-110}\right)$ values in $\mathrm{S}$ 347 containing ligands is in agreement with previous studies that reported $10^{3} \ln \beta$ values 348 for inorganic Cd (Yang et al., 2015) and organic Zn complexes (Fujii et al., 2014). 349 Among the complexes that contained $\mathrm{S}$ and $\mathrm{O}$ donor atoms in this study, their $35010^{3} \ln \left(\beta_{114-110}\right)$ values slightly differed. For instance, $\mathrm{Cd}(\mathrm{DMPS})\left(\mathrm{H}_{2} \mathrm{O}\right)_{2}^{-}$and $351 \mathrm{Cd}(\mathrm{GS})_{2}\left(\mathrm{H}_{2} \mathrm{O}\right)_{2}{ }^{2-}$ were complexed with two $\mathrm{S}$ donor atoms from the organic 352 molecules and two $\mathrm{O}$ donor atoms from water molecules. The average bond lengths of $353 \mathrm{Cd}-\mathrm{S}$ in $\mathrm{Cd}(\mathrm{DMPS})\left(\mathrm{H}_{2} \mathrm{O}\right)_{2}{ }^{-}(2.48 \AA)$ was shorter than that in $\mathrm{Cd}(\mathrm{GS})_{2}\left(\mathrm{H}_{2} \mathrm{O}\right)_{2}{ }^{2-}(2.545$ $354 \AA$, Table 1 and S3). The average Cd-O bond lengths in $\mathrm{Cd}(\mathrm{DMPS})\left(\mathrm{H}_{2} \mathrm{O}\right)_{2}{ }^{-}(2.95 \AA)$ 355 were longer than that of $\mathrm{Cd}(\mathrm{GS})_{2}\left(\mathrm{H}_{2} \mathrm{O}\right)_{2}{ }^{2-}(2.415 \AA)$. Our data suggests that chelators 356 with $\mathrm{S}$ ligands significantly change the bond lengths between $\mathrm{Cd}$ and other donor 357 atoms than $\mathrm{S}$ which might contribute to the lower $10^{3} \ln \left(\beta_{114-110}\right)$ value in the chelating 358 Cd(DMPS $)_{2}^{4-}$ complex. 

with four $\mathrm{S}$ and no $\mathrm{O}$ donor atoms, was smaller compared to $\mathrm{Cd}(\mathrm{DMPS})\left(\mathrm{H}_{2} \mathrm{O}\right)_{2}^{-}$

(Table 3 and Fig. 3). This observation agrees with previously published calculations of $\mathrm{Zn}$ sulfides where the smallest fractionation occurred in $\mathrm{Zn}$ sulfide complexes with four $\mathrm{S}$ donor atoms compared to $\mathrm{Zn}$ sulfide complexes contained mixtures of S and $\mathrm{O}$ donor atoms (Fujii et al., 2011). Together, our data suggests that a large shift towards light isotopes occurs when $\mathrm{Cd}$ is complexed to a chelating organic ligand with two or four $\mathrm{S}$ donor atoms when compared non-chelating $\mathrm{S}$ donor atoms and $\mathrm{O} / \mathrm{N}$ donor atoms in general. and $\mathrm{Cu}$ (Ryan et al., 2014) complexes reported a direct relation between the stability of complexes and the extent and isotope fractionation factors. This relation was also observed in our data, however, the difference of $10^{3} \ln \left(\beta_{114-110}\right)$ values between metal chelator CdEDTA and $\mathrm{Cd}(\text { his })_{2} \mathrm{H}_{2} \mathrm{O}$ was comparably small $\left(0.027\right.$ at $25^{\circ} \mathrm{C}$, Fig. 2 and Table 3). Though CdEDTA forms more stable complexes than Cd-histidine complexes (Sóvágó and Várnagy, 2013; Karak et al., 2016), the coordination number was six for both complexes while the CdEDTA had four $\mathrm{O}$ and two $\mathrm{N}$ donor atoms and $\mathrm{Cd}(\text { his })_{2} \mathrm{H}_{2} \mathrm{O}$ had four $\mathrm{N}$ and two $\mathrm{O}$ donor atoms, and the average bond lengths 377 between the central $\mathrm{Cd}$ atom and its donor atoms were very similar: CdEDTA 2.367 fractionation between the two complexes might have been demonstrated by the 
distinct coordination and bond lengths of the two complexes.

\subsection{Error analysis for Cd isotope fractionation}

Vacuo and solvation models can cause isotope fractionation factors inaccuracies (Hill and Schauble, 2008; Yang et al., 2015). In ideal vacuum gaseous conditions, the influence of the surrounding environment such as solvents on the solute molecules in the real system is ignored. To overcome this limitation, some solvent models were established to simulate the effects of solvents on solutes. The polarized continuum models (PCMs) are widely used to simulate the aqueous environment (Tomasi et al., 2005; Tsipis, 2014). However, Yang et al. (2015) found that the bond lengths optimized by IEFPCM model are larger than those by vacuo model and the $10^{3} \ln \left(\beta_{114}\right.$ 110) results calculated in the IEFPCM model are smaller than those in vacuo model, and thought that the optimized structures and $\ln \beta$ values of $\mathrm{Cd}$ complexes calculated in vacuo are more consistent with the experimental data. For comparison, the implicit solvation models IEFPCM (the integral-equation-formalism versions of PCM) and CPCM (conductor-like PCM) were used to calculate the optimized molecular structures and $10^{3} \ln \left(\beta_{114-110}\right)$ at $25^{\circ} \mathrm{C}$ for studied complexes (Table $\mathrm{S} 4$ and $\mathrm{S} 5$ ), as well as the model of $\mathrm{Cd}\left(\mathrm{H}_{2} \mathrm{O}\right)_{6}{ }^{2+}$ with second hydration sphere $\mathrm{Cd}\left(\mathrm{H}_{2} \mathrm{O}\right)_{18}{ }^{2+}$ (Table S6). Our calculation showed that most of the bond lengths optimized in solution by this study were larger than those in vacuum (Table S4). This was agreement with the results of inorganic $\mathrm{Cd}$ complexes (Yang et al., 2015). For $10^{3} \ln \left(\beta_{114-110}\right)$ values, not 
403

404

405

406

407

408

409

410

411

412

413

414

415

416

417

418

419

420

421

422

423

424

only does difference exist between two implicit models and vacuum model but also between two implicit models. By comparing with vacuum model, IEFPCM and CPCM solvation models decrease the $10^{3} \ln \beta$ of $\mathrm{Cd}\left(\mathrm{H}_{2} \mathrm{O}\right) 4^{2+}$ by 0.346 and 0.221 at $25^{\circ} \mathrm{C}$ respectively, and increase the $10^{3} \ln \beta$ of $\mathrm{Cd}\left(\mathrm{H}_{2} \mathrm{O}\right)_{6}{ }^{2+}$ by 0.139 and 0.166 at $25^{\circ} \mathrm{C}$ respectively. For $\mathrm{Cd}(\mathrm{Hcit})\left(\mathrm{H}_{2} \mathrm{cit}\right)^{-}, \mathrm{CdH}(\mathrm{cit})\left(\mathrm{H}_{2} \mathrm{O}\right)_{4}, \mathrm{Cd}(\mathrm{cit})\left(\mathrm{H}_{2} \mathrm{O}\right)_{3}{ }^{-}$and $\mathrm{Cd}(\text { his })_{2} \mathrm{H}_{2} \mathrm{O}$, IEFPCM and CPCM model decrease the $10^{3} \ln \beta$ by $0.175-0.580$ and $0.206-0.567$ and increase the $10^{3} \ln \beta$ of $\mathrm{Cd}(\mathrm{cys})\left(\mathrm{H}_{2} \mathrm{O}\right)_{3}{ }^{2+}$ by 0.281 and 0.401 at $25^{\circ} \mathrm{C}$ respectively. For $\mathrm{Cd}(\mathrm{cit}){ }_{2}{ }^{4-}$, CdEDTA, Cd(DMPS) ${ }_{2}{ }^{4-}$, these two models increase the $10^{3} \ln \beta$ by less than 0.1 at $25^{\circ} \mathrm{C}$. For $\mathrm{Cd}(\mathrm{GS})_{2}\left(\mathrm{H}_{2} \mathrm{O}\right)_{2}{ }^{2-}$, the IEFPCM solvation model decrease the $10^{3} \ln \beta$ by 0.109 and $\mathrm{CPCM}$ model increase the $10^{3} \ln \beta$ by less than 0.1 at $25^{\circ} \mathrm{C}$, the implicit solvation models have different effects on Cd isotope fractionation (Table S5). The main reason may be that the simple harmonic vibrational frequencies have been polluted by translation and rotation which make the inaccurate for frequencies data in solvation models (Yang et al., 2015), and the levels of "pollution" may be different for different Cd complexes.

Setting the second hydration sphere is able to make the calculated frequencies closer to the experimental values and improve the $10^{3} \ln \beta$ for Ni and $\mathrm{Zn}$ (Fujii et al., 2014), the same phenomenon may occur in Cd hydrate species. Our calculation showed that for $\mathrm{Cd}\left(\mathrm{H}_{2} \mathrm{O}\right)_{6}{ }^{2+}$, the $10^{3} \ln \beta$ values for the explicit model as $\mathrm{Cd}\left(\mathrm{H}_{2} \mathrm{O}\right)_{18}{ }^{2+}$ is 2.377 and $1.990,1.923$ for explicit model + IEFPCM and explicit model + CPCM at $25^{\circ} \mathrm{C}$ respectively. Compared with the vacuum model, the explicit model increases the $10^{3} \ln \beta$ values and explicit + implicit model decrease them (Table S6). The total 
symmetric stretching mode of hexaaqua complexes, $v_{1} \mathrm{CdO}_{6}$, is shown in Table S6. The calculated $v_{1}$ frequency values of large cluster $\mathrm{Cd}\left(\mathrm{H}_{2} \mathrm{O}\right)_{18}{ }^{2+}, \mathrm{Cd}\left(\mathrm{H}_{2} \mathrm{O}\right)_{6}{ }^{2+}+$ IEFPCM and $\mathrm{Cd}\left(\mathrm{H}_{2} \mathrm{O}\right)_{6}{ }^{2+}+\mathrm{CPCM}$ are closer to previous calculation and experimental data than that of $\mathrm{Cd}\left(\mathrm{H}_{2} \mathrm{O}\right)_{6}{ }^{2+}$ (Table S6), which means solvation models make the frequency values closer the literature values and the solvent effect on $10^{3} \ln \beta$ values are needed to be considered.

Frequency is another most frequently mentioned factor that may cause uncertainties or errors of the calculated reduced partition function ratios (Schauble et al., 2003, 2004; Schauble et al., 2007; Méheut et al., 2007, 2009; Weeks et al., 2007; Yang et al., 2015). For lack of experimental vibrational frequency of Cd organic complexes, it is impossible to evaluate the RPFR errors for them, and different vibration frequencies may lead to discrepant uncertainty in $10^{3} \ln \left(\beta_{114-110}\right)$ values at $25 \square$ (Vogt et al., 1993; Schauble, 2007; Yang et al., 2015). Based on existing experimental frequency data of $\mathrm{Cd}(\mathrm{Hcit})\left(\mathrm{H}_{2} \mathrm{cit}\right)^{-}$and this calculation, the maximum difference between them is $3.187 \%$, and the average deviation is about $0.293 \%$. Based on Schauble $(2007,2011)$, calculated frequencies may lead to an error of less than $0.6 \%$ for $10^{3} \ln \left(\beta_{114-110}\right)$ values of $\mathrm{Cd}(\mathrm{Hcit})\left(\mathrm{H}_{2} \mathrm{cit}\right)^{-}$.

\subsection{Implications for Cd process tracing applications in biogeochemistry, supergene} geochemistry and environmental science

Metal isotope fractionation can be used to trace processes that control the 
distribution of an element in terrestrial and aquatic environments. Previous experimental studies hypothesized that the Cd isotope fractionation is strongly linked to $\mathrm{Cd}$ speciation to organic ligands with $\mathrm{S}$ donor atoms to detoxify and immobilize $\mathrm{Cd}$ in living organisms (Horner et al., 2013; Wiggenhauser et al., 2016, 2021; Imseng et al., 2019). Results by this study and Yang et al. (2015) revealed that an enrichment of light isotopes occurs in thiol ligands when compared to hydrated $\mathrm{Cd}$ and $\mathrm{Cd}$ bound to $\mathrm{O} / \mathrm{N}$ donor atoms of organic ligands, which will strengthen not only $\mathrm{Cd}$ isotopes as a process tracing tool, but also the understanding of $\mathrm{Cd}$ isotope cycling in aquatic and terrestrial systems. For example, to reduce inputs of the toxic trace metal $\mathrm{Cd}$ into the food chain of humans and animals, processes that control the mobility of $\mathrm{Cd}$ in terrestrial and aquatic environments need to be well understood. The results that heavy $\mathrm{Cd}$ isotopes preferably bind to oxygen and nitrogen donor atoms while light $\mathrm{Cd}$ isotopes bind to sulfur donor atoms of organic ligands compared to hydrated $\mathrm{Cd}^{2+}$ provides information on processes on the immobilization of $\mathrm{Cd}$ isotopes in living organisms which are related to Cd detoxification processes with sulfur.

Furthermore, the strongest $\mathrm{Cd}$ isotope fractionation compared to hydrated $\mathrm{Cd}$ occurred in chelating S donor ligands, particularly in a chelating S donor ligand in which $\mathrm{Cd}$ is exclusively bound to $\mathrm{S}$. Thus, our data confirms the hypothesis that the retention of light isotopes in roots and shoots of grasses (Wiggenhauser et al., 2016, 2021; Imseng et al., 2019) and membranes of E.Coli (Horner et al., 2013) could be induced by the immobilization of light $\mathrm{Cd}$ isotopes through strong $\mathrm{Cd}$ binding to chelators with S donor atoms such as phytochelatins (Clemens et al. 2019). This 
chelation would retain light $\mathrm{Cd}$ isotopes e.g., in the roots of cereals, while other chemical $\mathrm{Cd}$ species such as hydrated $\mathrm{Cd}$ that are enriched in heavy isotopes can be transported by membrane proteins towards the shoot. The $\mathrm{Cd}$ isotope fractionation induced by chelating thiols may have implications on $\mathrm{Cd}$ isotope fractionation in other plants than grasses. Cd hyperaccumulator plants can cope with high $\mathrm{Cd}$ concentrations and store, unlike cereals, the majority of the Cd taken up from soils in their shoots (Zhou et al. 2020). To cope with the high Cd shoot concentrations, $\mathrm{Cd}$ is mostly bound to $\mathrm{O}$ donor atoms of e.g., organic acids and to a lesser extent to $\mathrm{S}$ donors (Tian et al. 2011; Isaure et al. 2015). Based on our findings, the Cd isotope fractionation in $\mathrm{Cd}$ accumulating plants could potentially provide novel insights into the role of $\mathrm{Cd}$ binding to different donor atoms on the translocation of $\mathrm{Cd}$ within the shoot. Recent studies focused on $\mathrm{Cd}$ isotope fractionation in cacao since cacao beans often exceed the threshold values for $\mathrm{Cd}$ potentially leading to elevated $\mathrm{Cd}$ concentrations in chocolate (Moore et al. 2020; Barraza et al. 2019). Similar to grasses such as wheat, rice, and barley, cacao seems to retain $\mathrm{Cd}$ and its light isotopes in the roots (Moore et al. 2020). Our findings suggest that $\mathrm{Cd}$ binding to thiols may play also a crucial role to retain $\mathrm{Cd}$ in roots of cacao and thereby limit the $\mathrm{Cd}$ transport into cacao beans.

Our results further suggest that $\mathrm{Cd}$ ligands, especially thiols, may play a key role in $\mathrm{Cd}$ isotope fractionation in living organisms, soils, and waters. In this study, the $\mathrm{Cd}$ isotope fractionation between hydrated $\mathrm{Cd}$ and $\mathrm{Cd}$ chelated by $\mathrm{S}$ donor atoms was $~$ 1\%. The largest $\mathrm{Cd}$ isotope fractionation that has been observed between roots and shoots of plants that strongly retain light $\mathrm{Cd}$ isotopes in roots was around $0.60 \%$ 
491 (Wiggenhauser et al. 2016, 2021; Imseng et al. 2018; Moore et al. 2020). The 492 difference between our results and the experimentally determined $\mathrm{Cd}$ isotopes 493 fractionation between root and shoots may be caused by additional isotope effects that 494 complement isotope effects at equilibrium. The transfer from root to shoot includes 495 membrane transport (Deng et al. 2019). This transport requires fast binding of Cd to a 496 metal binding site of a membrane protein prior to unidirectional membrane transport 497 (Wang et al., 2014; Zhao et al., 2016). Thus, membrane transport might be at least 498 partly kinetically controlled (Köbberich and Vance, 2017). Kinetically controlled 499 processes favor light isotopes through their faster reaction rates (Wiederhold, 2015) 500 while type of metal binding sites of a membrane transproters (e.g., cysteine, histidine) 501 might play an additional role for isotope fractionation during membrane transport. 502 Together, our results suggest that equilibrium $\mathrm{Cd}$ isotope fractionation in plants 503 induced by binding of $\mathrm{Cd}$ to organic molecules occur in parallel to kinetic isotope 504 effects.

505 In soils, sediments, and water, organic matter poses an important binding site for $506 \mathrm{Cd}$ and partly controls the mobility of $\mathrm{Cd}$. For instance, soil organic matter derives 507 from decomposed biomass and provides a mixture of $\mathrm{O}, \mathrm{N}$, and $\mathrm{S}$ donor atoms for $\mathrm{Cd}$ 508 in the solid and liquid phase of the soil (Karlsson et al., 2007; Tiberg et al., 2018). 509 Besides processes such as Cd sulfide precipitation and $\mathrm{Cd}$ uptake into phytoplankton, 510 soluble organic ligands might significantly control the $\mathrm{Cd}$ distribution in water 511 columns and sediments during the oceanic Cd cycle (Guinoiseau et al., 2018). Our 512 data implies that $\mathrm{Cd}$ sorption of $\mathrm{Cd}$ to organic matter can enrich or deplete the 
513

514

515

516

517

518

519

hydrated $\mathrm{Cd}$ pool in heavy and could provide further insights into the role of specific binding sites of organic matter on $\mathrm{Cd}$ cycling in the environment.

\section{Conclusion}

This study provides a first prediction that describes $\mathrm{Cd}$ equilibrium isotope fractionation induced by $\mathrm{Cd}$ complexation to organic ligands. The $10^{3} \ln \beta$ of ${ }^{114} \mathrm{Cd} /{ }^{110} \mathrm{Cd}$ for these investigated complexes decreased in the order of $\mathrm{Cd}(\mathrm{Hcit})\left(\mathrm{H}_{2} \mathrm{cit}\right)^{-}>\mathrm{Cd}(\mathrm{cit})\left(\mathrm{H}_{2} \mathrm{O}\right)_{3}{ }^{-}>\mathrm{CdH}(\mathrm{cit})\left(\mathrm{H}_{2} \mathrm{O}\right)_{4}>\mathrm{CdEDTA}>\mathrm{Cd}(\mathrm{his})_{2} \mathrm{H}_{2} \mathrm{O}>$ $\mathrm{Cd}(\mathrm{cit})_{2}{ }^{4-} \approx \mathrm{Cd}\left(\mathrm{H}_{2} \mathrm{O}\right)_{6}{ }^{2+}>\mathrm{Cd}\left(\mathrm{H}_{2} \mathrm{O}\right)_{4}{ }^{2+}>\mathrm{Cd}(\mathrm{cys})\left(\mathrm{H}_{2} \mathrm{O}\right)_{3}{ }^{2+}>\mathrm{Cd}(\mathrm{GS})_{2}\left(\mathrm{H}_{2} \mathrm{O}\right)_{2}{ }^{2-}>$ $\mathrm{Cd}(\mathrm{DMPS})\left(\mathrm{H}_{2} \mathrm{O}\right)_{2}{ }^{-}>\mathrm{Cd}(\mathrm{DMPS})_{2}^{4-}$ at $0 \sim 100^{\circ} \mathrm{C}$. The sequence reveals that $\mathrm{Cd}$ complexation to organic ligands with $\mathrm{O}$ and $\mathrm{N}$ donor atoms are enriched in heavy isotopes while to organic ligands with $\mathrm{S}$ donor atoms are enriched with light isotopes. These results provide important information to advance $\mathrm{Cd}$ isotopes as a process tracing tool in complex biological systems and further improve the understanding of Cd isotope cycling in aquatic and terrestrial systems.

\section{Acknowledgments}

This research was supported financially by the National Natural Science Foundation of China (No. 41872160); the Key Project of National Natural Science Foundation of China (No. 41530315); the DREAM project of MOST of China (2016YFC0600401); 
and the Swiss national research foundation (Early Postdoc.mobility, P2EZP2178618). We are also grateful for Professor Wang Zhixiang who provided us the chance to conduct this study.

\section{Appendices. Supplementary material}

Table S1: Comparing the experimental vibrational frequencies with calculated results $\left({ }^{110} w\right)$ employed by four different exchange correlation functionals for $\mathrm{Cd}($ Hcit $)\left(\mathrm{H}_{2} \text { cit }\right)^{-}$. Table S2: The fitting factors A, B for $10^{3} \ln \left(\beta_{114-110}\right)=\mathrm{A} \times 10^{6} / \mathrm{T}^{2}+\mathrm{B}(\mathrm{T}$ is K). Table S3: The donor atoms, coordinated bond lengths $(\AA)$ and mean bond lengths $(\AA)$ for Cd complexes. Table S4a: Optimized bond lengths $(\AA)$ of the Cd hydration complexes and citrate complexes calculated with solvation models. Table S4b: Optimized bond lengths $(\AA)$ of the organic Cd complexes calculated with solvation models. Table S5: The $10^{3} \ln \left(\beta_{114-110}\right)$ of Cd complexes calculated in vacuo and solvation models (IEFPCM, CPCM) at $25^{\circ} \mathrm{C}$. Table S6: The vibrational frequencies $\left({ }^{110} w\right)$ and $10^{3} \ln \beta$ values of $\mathrm{Cd}\left(\mathrm{H}_{2} \mathrm{O}\right)_{6}{ }^{2+}$ and $\mathrm{Cd}\left(\mathrm{H}_{2} \mathrm{O}\right)_{18}{ }^{2+}$.

\section{References}

Albarede, F., Télouk, P., Balter, V., Bondanese, V.P., Albalat, E., Oger, P., Bonaventura, P., Miossec, P., Fujii, T., 2016. Medical applications of Cu, Zn, and S isotope effects. Metallomics 8, 1056-1070. 
Albarède, F., Telouk, P., Lamboux, A., Jaouen, K., Balter, V., 2011. Isotopic evidence of unaccounted for Fe and $\mathrm{Cu}$ erythropoietic pathways. Metallomics 3, 926-933.

Balter, V., Lamboux, A., Zazzo, A., Télouk, P., Leverrier, Y., Marvel, J., Moloney, A.P., Monahan, F.J., Schmidt, O., Albarède, F., 2013. Contrasting Cu, Fe, and $\mathrm{Zn}$ isotopic patterns in organs and body fluids of mice and sheep, with emphasis on cellular fractionation. Metallomics 5, 1470-1482.

Becke, A.D., 1993a. Density- functional thermochemistry. III. The role of exact exchange. J. Chem. Phys. 98, 5648-5652.

Becke, A.D., 1993b. A new mixing of Hartree-Fock and local density- functional theories. J. Chem. Phys. 98, 1372-1377.

Bertoli, A.C., Carvalho, R., Freitas, M.P., Ramalho, T.C., Mancini, D.T., Oliveira, M.C., de Varennes, A., Dias, A., 2015. Theoretical spectroscopic studies and identification of metal-citrate $(\mathrm{Cd}$ and $\mathrm{Pb})$ complexes by ESI-MS in aqueous solution. Spectrochim. Acta Part A Mol. Biomol. Spectrosc. 137, 271-280.

Bigalke, M., Weyer, S., Wilcke, W., 2010. Copper isotope fractionation during complexation with insolubilized humic acid. Environ. Sci. Technol. 44, 54965502.

Bigeleisen, J., Mayer, M.G., 1947. Calculation of equilibrium constants for isotopic exchange reactions. J. Chem. Phys. 15, 261-267.

Cao, Z.-Y., Sun, L.-H., Mou, R.-X., Zhou, R., Zhu, Z.-W., Chen, M.-X., 2014. A novel method for the simultaneous analysis of seven biothiols in rice (Oryza sativa L.) using hydrophilic interaction chromatography coupled with 
Cao, Z.-Z., Qin, M.-L., Lin, X.-Y., Zhu, Z.-W., Chen, M.-X., 2018. Sulfur supply reduces cadmium uptake and translocation in rice grains (Oryza sativa L.) by enhancing iron plaque formation, cadmium chelation and vacuolar sequestration. Environ. Pollut. 238, 76-84.

Carignan, J., Cardinal, D., Eisenhauer, A., Galy, A., Rehkämper, M., Wombacher, F., Vigier, N., 2004. A reflection on $\mathrm{Mg}, \mathrm{Cd}, \mathrm{Ca}, \mathrm{Li}$ and $\mathrm{Si}$ isotopic measurements and related reference materials. Geostand. Geoanalytical Res. 28, 139-148.

Chrastný, V., Čadková, E., Vaněk, A., Teper, L., Cabala, J., Komárek, M., 2015. Cadmium isotope fractionation within the soil profile complicates source identification in relation to $\mathrm{Pb}-\mathrm{Zn}$ mining and smelting processes. Chem. Geol. 405, 1-9.

Clark, T., Chandrasekhar, J., Spitznagel, G.W., Schleyer, P.V.R., 1983. Efficient diffuse function-augmented basis sets for anion calculations. III. The $3-21+\mathrm{G}$ basis set for first-row elements, Li-F. J. Comput. Chem. 4, 294-301.

Clemens, S., 2019. Metal ligands in micronutrient acquisition and homeostasis. Plant. Cell Environ. 42, 2902-2912.

Clemens, S., Deinlein, U., Ahmadi, H., Höreth, S., Uraguchi, S., 2013. Nicotianamine is a major player in plant $\mathrm{Zn}$ homeostasis. BioMetals 26, 623-632.

Cloquet, C., Carignan, J., Libourel, G., Sterckeman, T., Perdrix, E., 2006. Tracing source pollution in soils using cadmium and lead isotopes. Environ. Sci. Technol. $40,2525-2530$. 
601

602

603

604

605

606

607

608

609

610

611

612

613

614

615

616

617

618

619

620

621

622

Colaneri, M.J., Vitali, J., Kirschbaum, K., 2013. Electron paramagnetic resonance spectroscopic study of copper hopping in doped bis(l-histidinato)cadmium dihydrate. J. Phys. Chem. A 117, 3414-3427.

Deng, F., Yu, M., Martinoia, E., Song, W.-Y., 2019. Ideal Cereals With Lower Arsenic and Cadmium by Accurately Enhancing Vacuolar Sequestration Capacity. Front. Genet. 10, 322.

Dennington, R., Keith, T., Millam, J., 2009. GaussView, Version 5.0.8. Semichem Inc.,Shawnee Mission, KS.

Delalande, O., Desvaux, H., Godat, E., Valleix, A., Junot, C., Labarre, J., Boulard, Y., 2010. Cadmium - glutathione solution structures provide new insights into heavy metal detoxification. FEBS J. 277, 5086-5096.

Francl, M.M., Pietro, W.J., Hehre, W.J., Binkley, J.S., Gordon, M.S., DeFrees, D.J., Pople, J.A., 1982. Self- consistent molecular orbital methods. XXIII. A polarization- type basis set for second- row elements. J. Chem. Phys. 77, 36543665.

Fransson, M. N., Barregard, L., Sällsten, G., Akerstrom, M., Johanson, G., 2014. Physiologically-based toxicokinetic model for cadmium using markov-chain monte carlo analysis of concentrations in blood, urine, and kidney cortex from living kidney donors. Toxicol. Sci. 141, 365-376.

Frisch, M.J., Trucks, G.W., Schlegel, H.B., Scuseria, G.E., Robb, M.A., Cheeseman, J.R., Scalmani, G., Barone, V., Mennucci, B., Petersson, G.A., Nakatsuji, H., Caricato, M., Li, X., Hratchian, H.P., Izmaylov, A.F., Bloino, J., Zheng, G., 
Sonnenberg, J.L., Hada, M., Ehara, M., Toyota, K., Fukuda, R., Hasegawa, J., Ishida, M., Nakajima, T., Honda, Y., Kitao, O., Nakai, H., Vreven, T., Montgomery Jr., J.A., Peralta, J.E., Ogliaro, F., Bearpark, M., Heyd, J.J., Brothers, E., Kudin, K.N., Staroverov, V.N., Kobayashi, R., Normand, J., Raghavachari, K., Rendell, A., Burant, J.C., Iyengar, S.S., Tomasi, J., Cossi, M., Rega, N., Millam, J. M., Klene, M., Knox, J.E., Cross, J.B., Bakken, V., Adamo, C., Jaramillo, J., Gomperts, R., Stratmann, R.E., Yazyev, O., Austin, A.J., Cammi, R., Pomelli, C., Ochterski, J.W., Martin, R.L., Morokuma, K., Zakrzewski, V.G., Voth, G.A., Salvador, P., Dannenberg, J.J., Dapprich, S., Daniels, A.D., Farkas, Ö., Foresman, J.B., Ortiz, J.V., Cioslowski, J., Fox, D.J., 2009. Gaussian 09, Revision A.01. Gaussian, Inc., Wallingford, CT

Fujii, T., Albarède, F., 2012. Ab initio calculation of the $\mathrm{Zn}$ isotope effect in phosphates, citrates, and malates and applications to plants and soil. PLoS One 7, e30726.

Fujii, T., Moynier, F., Blichert-Toft, J., Albarède, F., 2014. Density functional theory estimation of isotope fractionation of $\mathrm{Fe}, \mathrm{Ni}, \mathrm{Cu}$, and $\mathrm{Zn}$ among species relevant to geochemical and biological environments. Geochim. Cosmochim. Acta 140, $553-576$.

Fujii, T., Moynier, F., Pons, M.-L., Albarède, F., 2011. The origin of Zn isotope fractionation in sulfides. Geochim. Cosmochim. Acta 75, 7632-7643.

Guinoiseau, D., Galer, S.J.G., Abouchami, W., 2018. Effect of cadmium sulphide precipitation on the partitioning of $\mathrm{Cd}$ isotopes: Implications for the oceanic $\mathrm{Cd}$ 
cycle. Earth Planet. Sci. Lett. 498, 300-308.

646

647

648

649

650

651

652

653

654

655

656

657

658

659

660

661

662

663

664

665

666

Gunawardana, B., Singhal, N., Johnson, A., 2010. Amendments and their combined application for enhanced copper, cadmium, lead uptake byLolium perenne. Plant Soil 329, 283-294.

Hay, P.J., Wadt, W.R., 1985. Ab initio effective core potentials for molecular calculations.Potentials for $\mathrm{K}$ to $\mathrm{Au}$ including the outer most core orbitals. J. Chem. Phys. 82, 299-310.

Hill, P.S., Schauble, E.A., 2008. Modeling the effects of bond environment on equilibrium iron isotope fractionation in ferric aquo-chloro complexes. Geochim. Cosmochim. Acta 72, 1939-1958.

Hoch, E., Lin, W., Chai, J., Hershfinkel, M., Fu, D., Sekler, I., 2012. Histidine pairing at the metal transport site of mammalian $\mathrm{ZnT}$ transporters controls $\mathrm{Zn}^{2+}$ over $\mathrm{Cd}^{2+}$ selectivity. Proc. Natl. Acad. Sci. 109, 7202-7207.

Hoefs, J., 2015. Isotope fractionation processes of selected elements BT - stable isotope geochemistry, in: Hoefs, J. (Ed.), . Springer International Publishing, Cham, pp. 47-190.

Horner, T.J., Lee, R.B.Y., Henderson, G.M., Rickaby, R.E.M., 2013. Nonspecific uptake and homeostasis drive the oceanic cadmium cycle. Proc. Natl. Acad. Sci. $110,2500-2505$.

Horner, T.J., Rickaby, R.E.M., Henderson, G.M., 2011. Isotopic fractionation of cadmium into calcite. Earth Planet. Sci. Lett. 312, 243-253.

Imseng, M., Wiggenhauser, M., Keller, A., Müller, M., Rehkämper, M., Murphy, K., 
Kreissig, K., Frossard, E., Wilcke, W., Bigalke, M., 2019. Towards an understanding of the Cd isotope fractionation during transfer from the soil to the cereal grain. Environ. Pollut. 244, 834-844.

Imseng, M., Wiggenhauser, M., Keller, A., Müller, M., Rehkämper, M., Murphy, K., Kreissig, K., Frossard, E., Wilcke, W., Bigalke, M., 2018. Fate of Cd in agricultural soils: a stable isotope approach to anthropogenic impact, soil formation, and soil-plant cycling. Environ. Sci. Technol. 52, 1919-1928.

Isaure, M.-P., Huguet, S., Meyer, C.-L., Castillo-Michel, H., Testemale, D., Vantelon, D., Saumitou-Laprade, P., Verbruggen, N., Sarret, G., 2015. Evidence of various mechanisms of $\mathrm{Cd}$ sequestration in the hyperaccumulator Arabidopsis halleri, the non-accumulator Arabidopsis lyrata, and their progenies by combined synchrotron-based techniques. J. Exp. Bot. 66, 3201-3214.

Jalilehvand, F., Leung, B.O., Mah, V., 2009. Cadmium(II) complex formation with cysteine and penicillamine. Inorg. Chem. 48, 5758-5771.

John, S.G., Kunzmann, M., Townsend, E.J., Rosenberg, A.D., 2017. Zinc and cadmium stable isotopes in the geological record: A case study from the postsnowball Earth Nuccaleena cap dolostone. Palaeogeogr. Palaeoclimatol. Palaeoecol. 466, 202-208.

Jouvin, D., Louvat, P., Juillot, F., Maréchal, C.N., Benedetti, M.F., 2009. Zinc isotopic fractionation: why organic matters. Environ. Sci. Technol. 43, 57475754.

Kabata-Pendias, A., 2011. Trace elements in soils and plants, 4. ed. ed. CRC Press, 
690

691

692

693

694

695

696

697

698

699

700

701

702

703

704

705

706

707

708

709

710

Karak, T., Paul, R.K., Das, D.K., Boruah, R.K., 2016. Complexation of DTPA and EDTA with $\mathrm{Cd}^{2+}$ : stability constants and thermodynamic parameters at the soilwater interface. Environ. Monit. Assess. 188, 670.

Karlsson, T., Elgh-Dalgren, K., Björn, E., Skyllberg, U., 2007. Complexation of cadmium to sulfur and oxygen functional groups in an organic soil. Geochim. Cosmochim. Acta 71, 604-614.

Khan, M.A., Castro-Guerrero, N., Mendoza-Cozatl, D.G., 2014. Moving toward a precise nutrition: preferential loading of seeds with essential nutrients over nonessential toxic elements. Front. Plant Sci. 5, 51.

Köbberich, M., Vance, D., 2017. Kinetic control on Zn isotope signatures recorded in marine diatoms. Geochim. Cosmochim. Acta 210, 97-113.

Kovács, A., Nemcsok, D.S., Kocsis, T., 2010. Bonding interactions in EDTA complexes. J. Mol. Struct. THEOCHEM 950, 93-97.

Krishnan, R., Binkley, J.S., Seeger, R., Pople, J.A., 1980. Self- consistent molecular orbital methods. XX. A basis set for correlated wave functions. J. Chem. Phys. $72,650-654$.

Lambelet, M., Rehkämper, M., van de Flierdt, T., Xue, Z., Kreissig, K., Coles, B., Porcelli, D., Andersson, P., 2013. Isotopic analysis of Cd in the mixing zone of Siberian rivers with the Arctic Ocean-New constraints on marine Cd cycling and the isotope composition of riverine Cd. Earth Planet. Sci. Lett. 361, 64-73.

Larner, F., McLean, C., Halliday, A., Roberts, B., 2019. Copper isotope compositions 
of superoxide dismutase and metallothionein from post-mortem human frontal cortex. Inorganics 7, 86.

Le Croizier, G., Lacroix, C., Artigaud, S., Le Floch, S., Munaron, J.-M., Raffray, J., Penicaud, V., Rouget, M.-L., Laë, R., Tito De Morais, L., 2019. Metal subcellular partitioning determines excretion pathways and sensitivity to cadmium toxicity in two marine fish species. Chemosphere $217,754-762$.

Lee, C., Yang, W., Parr, R.G., 1988. Development of the Colle-Salvetti correlationenergy formula into a functional of the electron density. Phys. Rev. B 37, 785789.

Leitenmaier, B., Witt, A., Witzke, A., Stemke, A., Meyer-Klaucke, W., Kroneck, P.M.H., Küpper, H., 2011. Biochemical and biophysical characterisation yields insights into the mechanism of a $\mathrm{Cd} / \mathrm{Zn}$ transporting ATPase purified from the hyperaccumulator plant Thlaspi caerulescens. Biochim. Biophys. Acta Biomembr. 1808, 2591-2599.

Li, D., Li, M.-L., Liu, W.-R., Qin, Z.-Z., Liu, S.-A., 2018. Cadmium isotope ratios of standard solutions and geological reference materials measured by MC-ICP-MS. Geostand. Geoanalytical Res. 42, 593-605.

Liu, Q., Tossell, J.A., Liu, Y., 2010. On the proper use of the Bigeleisen-Mayer equation and corrections to it in the calculation of isotopic fractionation equilibrium constants. Geochim. Cosmochim. Acta 74, 6965-6983.

Liu, Y., Xiao, T., Perkins, R.B., Zhu, J., Zhu, Z., Xiong, Y., Ning, Z., 2017. Geogenic cadmium pollution and potential health risks, with emphasis on black shale. J. 
Geochemical Explor. 176, 42-49.

Marentes, E., Rauser, W.E., 2007. Different proportions of cadmium occur as Cdbinding phytochelatin complexes in plants. Physiol. Plant. 131, 291-301.

Maret, W., Moulis, J.-M., 2013. The bioinorganic chemistry of cadmium in the context of its toxicity. Met. Ions Life Sci. 11, 1-29.

Marković, T., Manzoor, S., Humphreys-Williams, E., Kirk, G.J.D., Vilar, R., Weiss, D.J., 2017. Experimental determination of zinc isotope fractionation in complexes with the phytosiderophore 2'-deoxymugeneic acid (DMA) and its structural analogues, and implications for plant uptake mechanisms. Environ. Sci. Technol. 51, 98-107.

McLean, A.D., Chandler, G.S., 1980. Contracted Gaussian basis sets for molecular calculations. I. Second row atoms, Z=11-18. J. Chem. Phys. 72, 5639-5648.

McLean, J.E., Pabst, M.W., Miller, C.D., Dimkpa, C.O., Anderson, A.J., 2013. Effect of complexing ligands on the surface adsorption, internalization, and bioresponse of copper and cadmium in a soil bacterium, Pseudomonas putida. Chemosphere 91, 374-382.

Méheut, M., Lazzeri, M., Balan, E., Mauri, F., 2007. Equilibrium isotopic fractionation in the kaolinite, quartz, water system: Prediction from firstprinciples density-functional theory. Geochim. Cosmochim. Acta 71, 3170-3181.

Méheut, M., Lazzeri, M., Balan, E., Mauri, F., 2009. Structural control over equilibrium silicon and oxygen isotopic fractionation: A first-principles densityfunctional theory study. Chem. Geol. 258, 28-37. 
Moore, R.E.T., Ullah, I., de Oliveira, V.H., Hammond, S.J., Strekopytov, S., Tibbett, M., Dunwell, J.M., Rehkämper, M., 2020. Cadmium isotope fractionation reveals genetic variation in Cd uptake and translocation by Theobroma cacao and role of natural resistance-associated macrophage protein 5 and heavy metal ATPase-family transporters. Hortic. Res. 7, 71.

Morgan, J.L.L., Wasylenki, L.E., Nuester, J., Anbar, A.D., 2010. Fe Isotope fractionation during equilibration of $\mathrm{Fe}^{-}$organic complexes. Environ. Sci. Technol. 44, 6095-6101.

Moynier, F., Fujii, T., 2017. Theoretical isotopic fractionation of magnesium between chlorophylls. Sci. Rep. 7, 6973.

Moynier, F., Fujii, T., Shaw, A.S., Le Borgne, M., 2013. Heterogeneous distribution of natural zinc isotopes in mice. Metallomics 5, 693-699.

Pal, R., Kaur, R., Rajwar, D., Rai, J., 2019. Induction of non-protein thiols and phytochelatins by cadmium in Eichhornia crassipes. Int. J. Phytoremediation 21, $1-9$.

Pallavicini, N., Engström, E., Baxter, D.C., Öhlander, B., Ingri, J., Rodushkin, I., 2014. Cadmium isotope ratio measurements in environmental matrices by MCICP-MS. J. Anal. At. Spectrom. 29, 1570-1584.

Panfili, F., Schneider, A., Vives, A., Perrot, F., Hubert, P., Pellerin, S., 2009. Cadmium uptake by durum wheat in presence of citrate. Plant Soil 316, 299-309. Prévéral, S., Gayet, L., Moldes, C., Hoffmann, J., Mounicou, S., Gruet, A., Reynaud, F., Lobinski, R., Verbavatz, J.-M., Vavasseur, A., Forestier C., 2009. A common 
highly conserved cadmium detoxification mechanism from bacteria to humans: heavy metal tolerance conferred by the atp-binding cassette (abc) transporter sphmt1 requires glutathione but not metal-chelating phytochelatin peptides. J. Biol. Chem. 284, 4936-4943.

Puschenreiter, M., Gruber, B., Wenzel, W.W., Schindlegger, Y., Hann, S., Spangl, B., Schenkeveld, W.D.C., Kraemer, S.M., Oburger, E., 2017. Phytosiderophoreinduced mobilization and uptake of $\mathrm{Cd}, \mathrm{Cu}, \mathrm{Fe}, \mathrm{Ni}, \mathrm{Pb}$ and $\mathrm{Zn}$ by wheat plants grown on metal-enriched soils. Environ. Exp. Bot. 138, 67-76.

Ramalho, T.C., Figueroa-Villar, J.D., 2002. Thermodynamic evaluation of complexes of zinc and cadmium that mimetize metallic centers in transcription factors. J. Mol. Struct. THEOCHEM 580, 217-223.

Rehkämper, M., Wombacher, F., Horner, T.J., Xue, Z., 2011. Natural and anthropogenic $\mathrm{Cd}$ isotope variations. Handbook of Environmental Isotope Geochemistry. Springer, Berlin Heidelberg, pp. 125-154.

Richet, P., Bottinga, Y., Javoy, M., 1977. A Review of hydrogen, carbon, nitrogen, oxygen, sulphur, and chlorine stable isotope fractionation among gaseous molecules. Annu. Rev. Earth Planet. Sci. 5, 65-110.

Ryan, B.M., Kirby, J.K., Degryse, F., Scheiderich, K., McLaughlin, M.J., 2014. Copper isotope fractionation during equilibration with natural and synthetic ligands. Environ. Sci. Technol. 48, 8620-8626.

Salmanzadeh, M., Hartland, A., Stirling, C.H., Balks, M.R., Schipper, L.A., Joshi, C., George, E., 2017. Isotope tracing of long-term cadmium fluxes in an agricultural 
soil. Environ. Sci. Technol. 51, 7369-7377.

800

801

802

803

804

805

806

807

808

809

810

811

812

813

814

815

Satarug, S., Garrett, S.H., Sens, M.A., Sens, D.A., 2010. Cadmium, environmental exposure, and health outcomes. Environ. Health Perspect. 118, 182-190.

Schauble, E., Rossman, G.R., Taylor, H.P., 2004. Theoretical estimates of equilibrium chromium-isotope fractionations. Chem. Geol. 205, 99-114.

Schauble, E.A., 2007. Role of nuclear volume in driving equilibrium stable isotope fractionation of mercury, thallium, and other very heavy elements. Geochim. Cosmochim. Acta 71, 2170-2189.

Schauble, E. A., 2011. First-principles estimates of equilibrium magnesium isotope fractionation in silicate, oxide, carbonate and hexaaquamagnesium(2+) crystals. Geochim. Cosmochim. Acta 75(3), 844-869.

Schauble, E. A., Rossman, G.R., Taylor, H.P., 2003. Theoretical estimates of equilibrium chlorine-isotope fractionations. Geochim. Cosmochim. Acta 67, $3267-3281$.

Seth, C., Remans, T., Keunen, E., Jozefczak, M., Gielen, H., Opdenakker, K., Weyens, N., Vangronsveld, J., Cuypers, A., 2011. Phytoextraction of toxic metals: A central role for glutathione. Plant. Cell Environ. 35, 334-346.

Sieber, M., Conway, T.M., de Souza, G.F., Obata, H., Takano, S., Sohrin, Y., Vance, D., 2019. Physical and biogeochemical controls on the distribution of dissolved cadmium and its isotopes in the Southwest Pacific Ocean. Chem. Geol. 511, $494-509$.

Sigel, A., Sigel, H., Sigel, R.K. (Eds.), 2013. Cadmium: from toxicity to essentiality, 
822 Siddiqui, K.A., Mehrotra, G.K., Narvi, S.S., Butcher, R.J., 2011. Molecular selfsolvation models. Chem. Rev. 105, 2999-3094. 
Tsipis, A.C., 2014. DFT flavor of coordination chemistry. Coord. Chem. Rev. 272, 129.

Urey, H.C., 1947. The thermodynamic properties of isotopic substances. J. Chem. Soc. $562-581$.

Vogt, N., Haaland, A., Martinsen, K.-G., Vogt, J., Grenthe, I., Li, K., MIlanova, R., Nakata, H., Nasiri, A., Tsuda, T., 1993. Molecular parameters of gaseous CdCl2 from electron diffraction and vibrational Spectroscopic data. Acta Chem. Scand. 47, 937-939.

Wang, K. T., Sitsel, O., Meloni, G., Autzen, H., Andersson, M., Klymchuk, T., Nielsen, A., Rees, D., Nissen, P., Gourdon, P., 2014. Structure and mechanism of $\mathrm{Zn}^{2+}$-transporting P-type ATPases. Nature 514.

Wang, M.-J., Wang, W.-X., 2009. Cadmium in three marine phytoplankton: Accumulation, subcellular fate and thiol induction. Aquat. Toxicol. 95, 99-107.

Wasylenki, L.E., Swihart, J.W., Romaniello, S.J., 2014. Cadmium isotope fractionation during adsorption to Mn oxyhydroxide at low and high ionic strength. Geochim. Cosmochim. Acta 140, 212-226.

Weeks, C.L., Anbar, A.D., Wasylenki, L.E., Spiro, T.G., 2007. Density functional theory analysis of molybdenum isotope fractionation. J. Phys. Chem. A 111, $12434-12438$.

Wei, R., Guo, Q., Wen, H., Liu, C., Yang, J., Peters, M., Hu, J., Zhu, G., Zhang, H., Tian, L., Han, X., Ma, J., Zhu, C., Wan, Y., 2016. Fractionation of stable cadmium isotopes in the cadmium tolerant ricinus communis and 
Wiederhold, J.G., 2015. Metal stable isotope signatures as tracers in environmental geochemistry. Environ. Sci. Technol. 49, 2606-2624.

Wierzbicka, M.H., Przedpełska, E., Ruzik, R., Ouerdane, L., Połeć-Pawlak, K., Jarosz, M., Szpunar, J., Szakiel, A., 2007. Comparison of the toxicity and distribution of cadmium and lead in plant cells. Protoplasma 231, 99.

Wiggenhauser, M., Aucour, A.-M., Bureau, S., Campillo, S., Telouk, P., Romani, M., Ma, J.F., Landrot, G., Sarret, G., 2021. Cadmium transfer in contaminated soilrice systems: Insights from solid-state speciation analysis and stable isotope fractionation. Environ. Pollut. 269, 115934.

Wiggenhauser, M., Bigalke, M., Imseng, M., Müller, M., Keller, A., Murphy, K., Kreissig, K., Rehkämper, M., Wilcke, W., Frossard, E., 2016. Cadmium isotope fractionation in soil-wheat systems. Environ. Sci. Technol. 50, 9223-9231.

Wiggenhauser, M., Bigalke, M., Imseng, M., Keller, A., Archer, C., Wilcke, W.,Frossard, E., 2018. Zinc isotope fractionation during grain filling of wheat and a comparison of zinc and cadmium isotope ratios in identical soil-plant systems. New Phytol. 219, 195-205.

Wombacher, F., Rehkämper, M., 2004. Problems and suggestions concerning the notation of cadmium stable isotope compositions and the use of reference materials. Geostand. Geoanalytical Res. 28, 173-178.

Wu, Z., Zhang, C., Yan, J., Ge, Y., 2013. Separation and quantification of cysteine, glutathione and phytochelatins in rice (Oryza sativa L.) upon cadmium exposure 
using reverse phase ultra performance liquid chromatography (RP-UPLC) with fluorescence detection. Anal. Methods 5, 6147-6152.

Yang, J., Li, Y., Liu, S., Tian, H., Chen, C., Liu, J., Shi, Y., 2015. Theoretical calculations of Cd isotope fractionation in hydrothermal fluids. Chem. Geol. 391, $74-82$.

Yang, W.-J., Ding, K.-B., Zhang, P., Qiu, H., Cloquet, C., Wen, H.-J., Morel, J.-L., Qiu, R.-L., Tang, Y.-T., 2019. Cadmium stable isotope variation in a mountain area impacted by acid mine drainage. Sci. Total Environ. 646, 696-703.

Zeini Jahromi, E., Gailer, J., Pickering, I.J., George, G.N., 2014. Structural characterization of $\mathrm{Cd}^{2+}$ complexes in solution with DMSA and DMPS. J. Inorg. Biochem. 136, 99-106.

Zelano, I.O., Cloquet, C., Fraysse, F., Dong, S., Janot, N., Echevarria, G., MontargèsPelletier, E., 2018. The influence of organic complexation on $\mathrm{Ni}$ isotopic fractionation and Ni recycling in the upper soil layers. Chem. Geol. 483, 47-55.

Zhang, S.-N., Gu, Y., Zhu, Z.-L., Hu, S.-H., Kopittke, P.M., Zhao, F.-J., Wang, P., 2021. Stable isotope fractionation of cadmium in the soil-rice-human continuum. Sci. Total Environ. 761, 143262.

Zhang, Y., Wen, H., Zhu, C., Fan, H., Cloquet, C., 2018. Cadmium isotopic evidence for the evolution of marine primary productivity and the biological extinction event during the Permian-Triassic crisis from the Meishan section, South China. Chem. Geol. 481, 110-118.

Zhang, Y., Wen, H., Zhu, C., Fan, H., Luo, C., Liu, J., Cloquet, C., 2016. Cd isotope 
Zhao, C.-M., Campbell, P., Wilkinson, K., 2016. When are metal complexes bioavailable? Environ. Chem. 13, 425-433.

Zhou, J.-W., Li, Z., Liu, M.-S., Yu, H.-M., Wu, L.-H., Huang, F., Luo, Y.-M., Christie, P., 2020. Cadmium Isotopic Fractionation in the Soil-Plant System during Repeated Phytoextraction with a Cadmium Hyperaccumulating Plant Species. Environ. Sci. Technol. 54, 13598-13609.

Zhu, C., Wen, H., Zhang, Y., Fan, H., Fu, S., Xu, J., Qin, T., 2013. Characteristics of Cd isotopic compositions and their genetic significance in the lead-zinc deposits of SW China. Sci. China Earth Sci. 56 (12), 2056-2065.

Zhu, C., Wen, H., Zhang, Y., Fan, H., 2016. Cadmium and sulfur isotopic compositions of the Tianbaoshan $\mathrm{Zn}-\mathrm{Pb}-\mathrm{Cd}$ deposit, Sichuan Province, China. Ore Geol. Rev. 76, 152-162.

Zhu, C., Wen, H., Zhang, Y., Yin, R., Cloquet, C., 2018. Cd isotope fractionation during sulfide mineral weathering in the Fule $\mathrm{Zn}-\mathrm{Pb}-\mathrm{Cd}$ deposit, Yunnan Province, Southwest China. Science of The Total Environment. 616-617, 64-72.

Zorrig, W., Rouached, A., Shahzad, Z., Abdelly, C., Davidian, J.-C., Berthomieu, P., 2010. Identification of three relationships linking cadmium accumulation to cadmium tolerance and zinc and citrate accumulation in lettuce. J. Plant Physiol. $167,1239-1247$. 
Fig. 1. Optimized molecular structures for various Cd species. a-b: Cd hydrate; c-f: Cd-citrate, the original source of the structure derives from Bertoli et al. (2015) and Fujii et al. (2012); g: CdEDTA (Kovács et al., 2010); h: Cd-histidine (Colaneri et al., 2013); i-j: Cd-DMPS (Zeini Jahromi et al., 2014); k: Cd-cysteine (Jalilehvand et al., 2009 and Fujii et al., 2014); 1: Cdglutathione (Delalande et al., 2010). Abbreviations are cit (citrate), EDTA (ethylenediaminetetraacetic acid), his (histidine), DMPS (dimercaptopropane sulfonic acid), cys (cysteine), and deprotonated glutathione (GSH) is shown as GS. Symbol keys: H (white), C (grey), N (blue), O (red), S (purple), Cd (yellow).

Fig. 2. Temperature dependence of $10^{3} \ln \left(\beta_{114-110}\right)$ for Cd hydrate, citrate, EDTA, histidine, DMPS, cysteine and glutathione complexes. X-axis shows the function of $10^{6} / \mathrm{T}^{2}$ (lower shaft) and corresponding temperature (upper shaft, $0-100 \square$ ), Y-axis shows the $10^{3} \ln \left(\beta_{114-110}\right)$ values.

Fig. 3. $\mathrm{Cd}\left({ }^{114} \mathrm{Cd} /{ }^{110} \mathrm{Cd}\right)$ isotopic variations with different donor atoms at $25^{\circ} \mathrm{C}$. The complexes complex is $\mathrm{Cd}(\mathrm{DMPS}){ }_{2}{ }^{4-}$.

Fig. 4. Reduced partition function ratios, $10^{3} \ln \left(\beta_{114-110}\right)$ vs. mean bond length $(\AA)$ at $25^{\circ} \mathrm{C}$ Just as 
$954 \mathrm{Cd}(\mathrm{cys})\left(\mathrm{H}_{2} \mathrm{O}\right)_{3}{ }^{2+}$ and $\mathrm{Cd}(\mathrm{GS})_{2}\left(\mathrm{H}_{2} \mathrm{O}\right)_{2}{ }^{2-} ; \mathrm{S}$ donor complex as $\mathrm{O}$, is $\mathrm{Cd}(\mathrm{DMPS})_{2}{ }^{4-}$.

955 


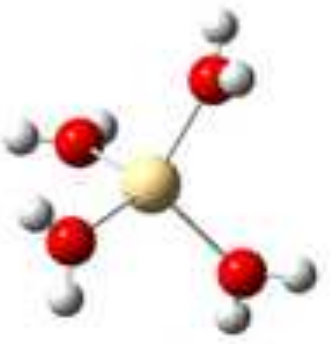

a) $\mathrm{Cd}\left(\mathrm{H}_{2} \mathrm{O}\right)_{4}^{2+}$

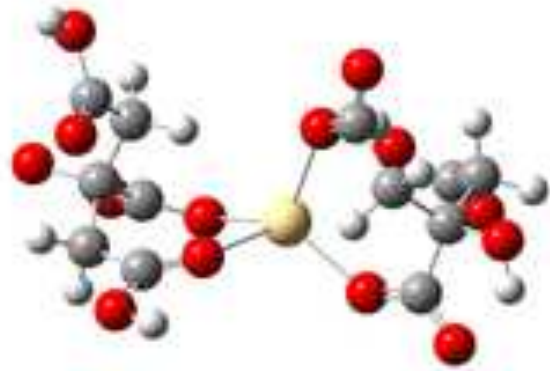

d) $\mathrm{Cd}(\mathrm{Hcit})\left(\mathrm{H}_{2} \text { cit }\right)^{-}$

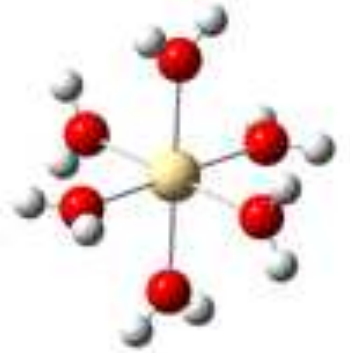

b) $\mathrm{Cd}\left(\mathrm{H}_{2} \mathrm{O}\right)_{6}{ }^{2+}$

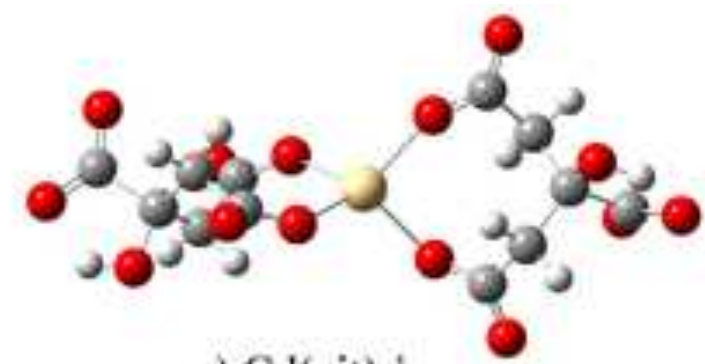

c) $\mathrm{Cd}(\text { cit })_{2}^{4-}$

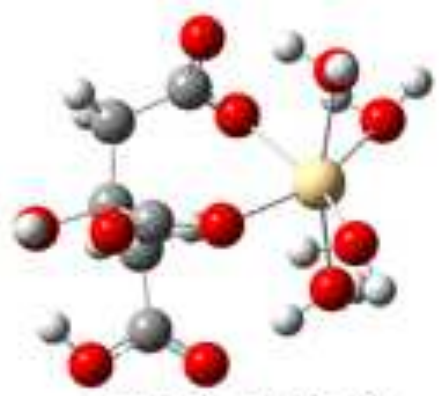

e) $\mathrm{CdH}(\mathrm{cit})\left(\mathrm{H}_{2} \mathrm{O}\right)_{4}$

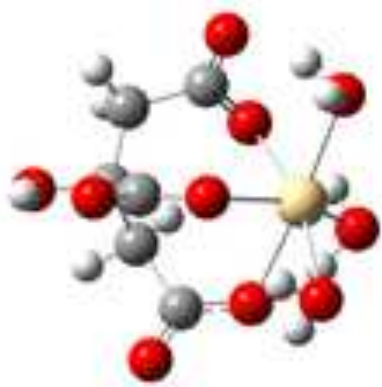

f) $\mathrm{Cd}($ cit $)\left(\mathrm{H}_{2} \mathrm{O}\right)_{3}$;

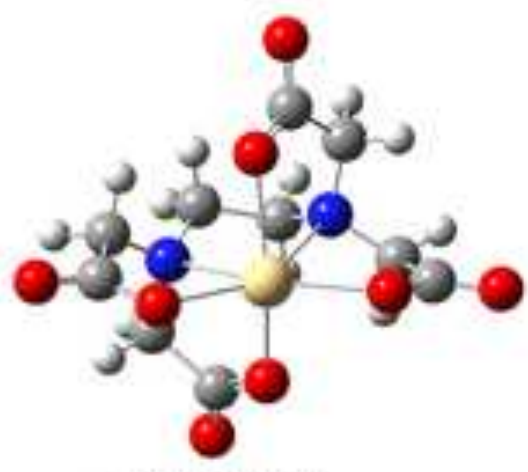

g) CdEDTA

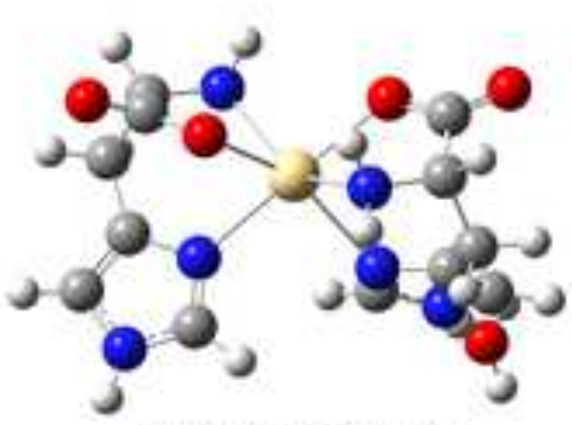

h) $\mathrm{Cd}(\text { his })_{2} \mathrm{H}_{2} \mathrm{O}$

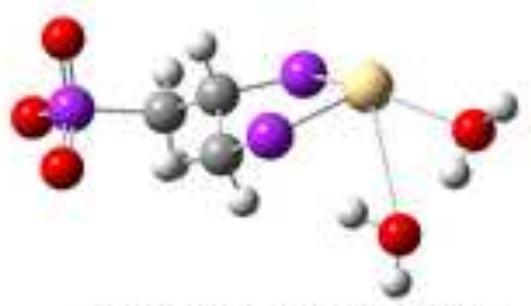

j) $\mathrm{Cd}(\mathrm{DMPS})\left(\mathrm{H}_{2} \mathrm{O}\right)_{2}$.

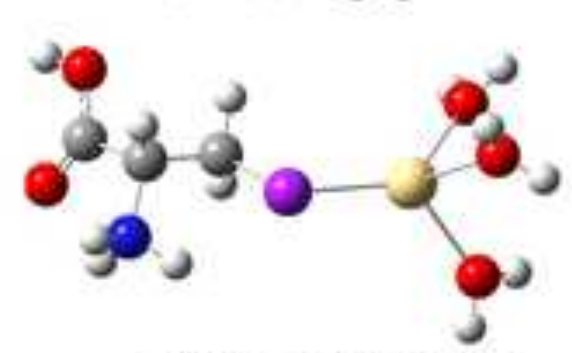

k) $\mathrm{Cd}(\mathrm{cys})\left(\mathrm{H}_{2} \mathrm{O}\right)_{3}{ }^{2+}$

$\mathrm{H} \mathrm{C} \mathrm{N} \mathrm{O} \mathrm{S} \mathrm{Cd}$ - 000

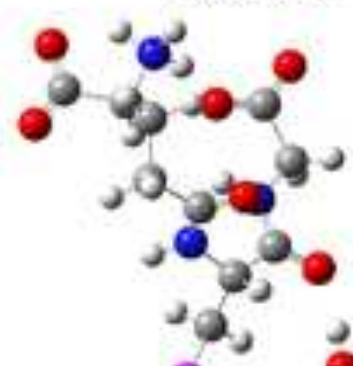

i) $\mathrm{Cd}(\mathrm{DMPS})_{2}{ }^{4}$
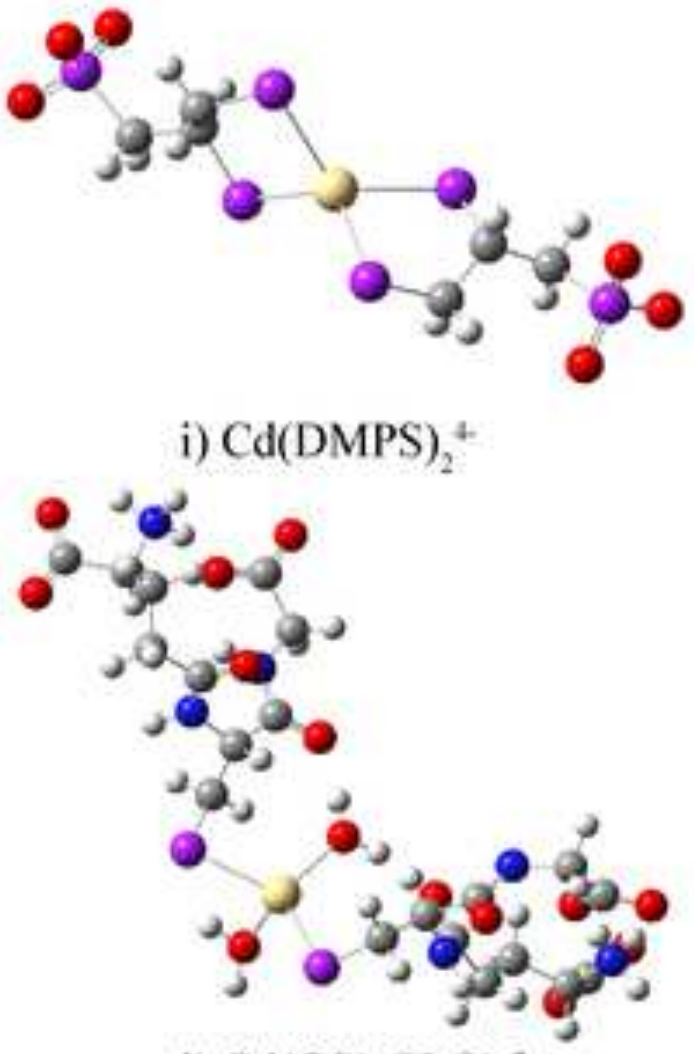

1) $\mathrm{Cd}(\mathrm{GS})_{2}\left(\mathrm{H}_{2} \mathrm{O}\right)_{2}{ }^{2 \cdot}$ 
Figure

Click here to access/download;Figure;FIG2.tif $\underline{\underline{ }}$

$\pi(\mathrm{C})$

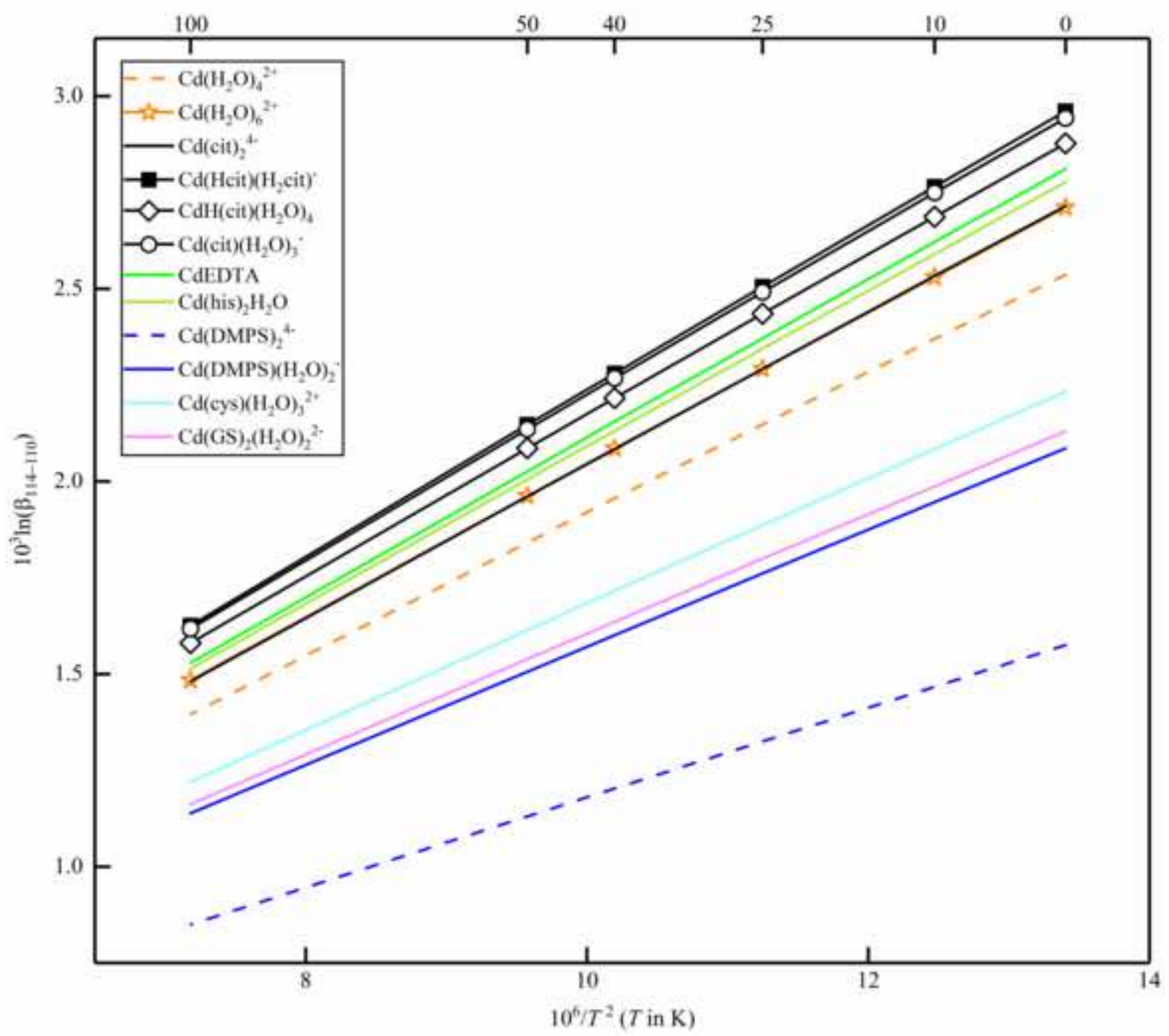




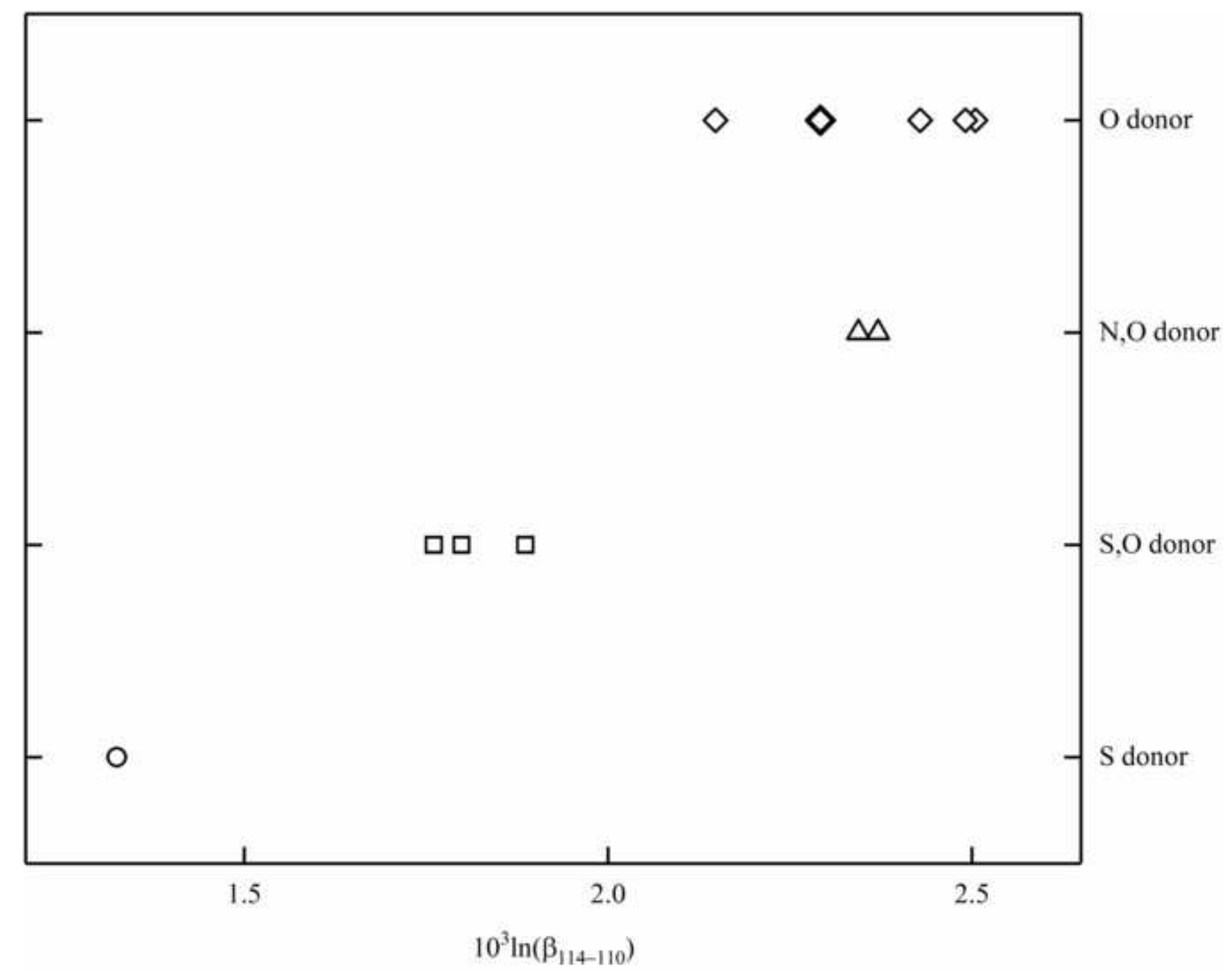




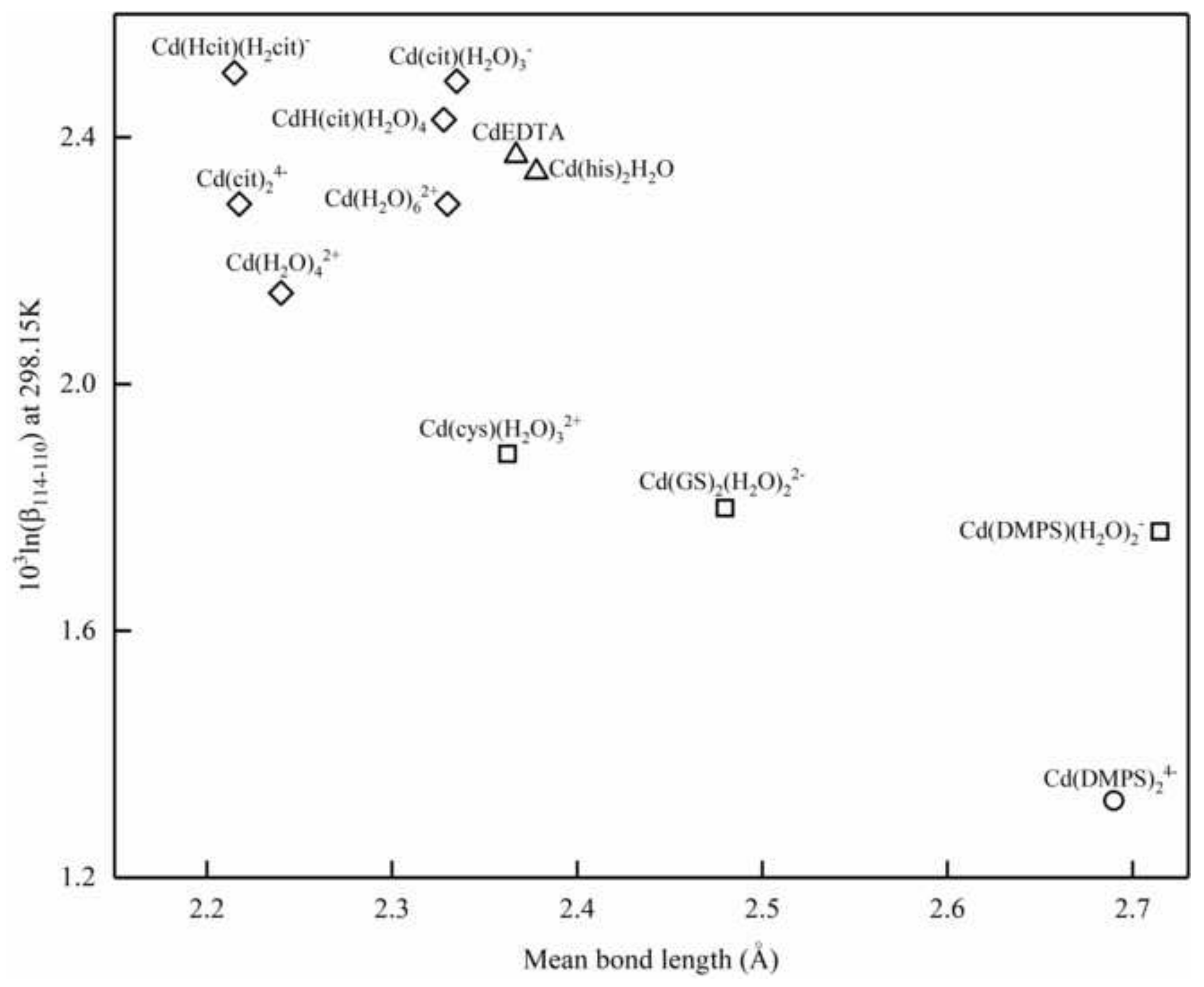


Table 1a Optimized bond lengths ( $(\AA)$ of the Cd hydration complexes and citrate complexes.

\begin{tabular}{|c|c|c|c|c|c|c|}
\hline & $\mathrm{Cd}\left(\mathrm{H}_{2} \mathrm{O}\right)_{4}{ }^{2+}$ & $\mathrm{Cd}\left(\mathrm{H}_{2} \mathrm{O}\right)_{6}{ }^{2+}$ & $\mathrm{Cd}(\mathrm{cit})_{2}^{4-}$ & $\mathrm{Cd}(\mathrm{Hcit})\left(\mathrm{H}_{2} \text { cit }\right)^{-}$ & $\mathrm{CdH}($ cit $)\left(\mathrm{H}_{2} \mathrm{O}\right)_{4}$ & $\mathrm{Cd}(\mathrm{cit})\left(\mathrm{H}_{2} \mathrm{O}\right)_{3}{ }^{-}$ \\
\hline \multirow{3}{*}{$\mathrm{Cd}-\mathrm{O}$} & 2.24 & 2.33 & $2.22,2.21$ & & & \\
\hline & & & & $2.14,2.38$ & $2.37,2.34,2.40$ & $2.43,2.42,2.35$ \\
\hline & $2.24^{\mathrm{a}}$ & $2.33^{\mathrm{a}}$ & $2.34-2.37^{\mathrm{b}}$ & & & \\
\hline
\end{tabular}

a Yang et al., 2015

b Bertoli et al., 2015

Table 1b Optimized bond lengths ( $\AA$ ) of the organic Cd complexes.

\begin{tabular}{|c|c|c|c|c|c|c|}
\hline & CdEDTA & $\mathrm{Cd}(\text { his })_{2} \mathrm{H}_{2} \mathrm{O}$ & $\mathrm{Cd}(\mathrm{DMPS})_{2}{ }^{4-}$ & $\mathrm{Cd}(\mathrm{DMPS})\left(\mathrm{H}_{2} \mathrm{O}\right)_{2}^{-}$ & $\mathrm{Cd}(\mathrm{cys})\left(\mathrm{H}_{2} \mathrm{O}\right)_{3}{ }^{2+}$ & $\mathrm{Cd}(\mathrm{GS})_{2}\left(\mathrm{H}_{2} \mathrm{O}\right)_{2}{ }^{2-}$ \\
\hline \multirow[t]{2}{*}{$\mathrm{Cd}-\mathrm{O}$} & $2.26,2.36$ & 2.26 & & $2.39,3.51$ & $2.33,2.32,2.32$ & $2.29,2.54$ \\
\hline & $2.24,2.40^{\mathrm{a}}$ & $2.48^{\mathrm{b}}$ & & $2.39^{c}$ & & \\
\hline \multirow{3}{*}{$\mathrm{Cd}-\mathrm{N}$} & 240 & $2.41,2.45$ & & & & \\
\hline & 2.40 & $2.41,2.48$ & & & & \\
\hline & $2.46^{\mathrm{a}}$ & $2.287,2.29^{b}$ & & & & \\
\hline \multirow{3}{*}{$\mathrm{Cd}-\mathrm{S}$} & & & 2.70,2.68, & 51045 & 48 & 251250 \\
\hline & & & $2.67,2.71$ & $2.51,2.45$ & 2.48 & $2.51,2.58$ \\
\hline & & & $2.57^{\mathrm{c}}$ & $2.48^{\mathrm{c}}$ & $2.52-2.54^{\mathrm{d}}$ & $2.53-2.55^{\mathrm{e}}$ \\
\hline
\end{tabular}

a Kovács et al., 2010

b Colaneri et al., 2013

c Zeini Jahromi et al., 2014

d Jalilehvand et al., 2009

e Isaure et al., 2015 
Table 2 Comparing the experimental vibrational frequencies with calculated results for

\begin{tabular}{cccccc}
\multicolumn{5}{c}{$\mathrm{Cd}(\mathrm{Hcit})\left(\mathrm{H}_{2} \mathrm{cit}\right)^{-}}$. \\
\cline { 3 - 6 }$w / \mathrm{cm}^{-1}$ & Vibration Modes & \multicolumn{5}{c}{$\mathrm{Cd}(\mathrm{Hcit})\left(\mathrm{H}_{2} \mathrm{cit}\right)^{-}$} \\
\hline$w_{1}$ & $\tau(\mathrm{HCH})+\mathrm{v}(\mathrm{CO})$ & 1027.05 & 1041.1681 & 1041.1686 & 0.0005 \\
$w_{2}$ & $\rho(\mathrm{HCH})+\mathrm{v}(\mathrm{CC})$ & 1078.98 & 1079.978 & 1079.9783 & 0.0003 \\
$w_{3}$ & $\tau(\mathrm{HCH})+\mathrm{v}(\mathrm{CC})$ & 1095.98 & 1084.5717 & 1084.5721 & 0.0004 \\
$w_{4}$ & $\delta_{\text {sciss }}(\mathrm{HCH})$ & 1207.78 & 1201.8587 & 1201.8594 & 0.0006 \\
$w_{5}$ & $\rho(\mathrm{HCH})+\mathrm{v}(\mathrm{CC})+\mathrm{v}(\mathrm{CO})$ & 1248.26 & 1256.977 & 1256.9772 & 0.0002 \\
$w_{6}$ & $\omega(\mathrm{HCH})+\delta(\mathrm{OH})$ & 1280.53 & 1282.3539 & 1282.3541 & 0.0002 \\
$w_{7}$ & $\mathrm{v}_{\mathrm{s}}$ & 1391.44 & 1387.1308 & 1387.1311 & 0.0002 \\
$w_{8}$ & $\mathrm{v}_{\mathrm{s}}(\mathrm{COO})$ & 1445.87 & 1444.8795 & 1444.8795 & 0.0000 \\
$w_{9}$ & $\mathrm{v}_{\text {as }}(\mathrm{COO})$ & 1638.70 & 1690.9311 & 1690.9322 & 0.0007 \\
$w_{10}$ & $\mathrm{v}(\mathrm{OH})$ & 3350.46 & 3328.6313 & 3328.6316 & 0.0001 \\
\hline & & & &
\end{tabular}

$\delta$ : scissoring vibration; $\rho$ : rocking vibration; $\omega$ : wagging vibration; $\tau$ : twisting vibration; $v_{\mathrm{s}}$ : symmetrical stretching vibration; $v_{\mathrm{as}}$ : asymmetrical stretching vibration.

${ }^{a}$ Experimental data obtained for Cd (not Cd isotope specific) by Bertoli et al. (2015).

Table 3 Calculated $10^{3} \ln \left(\beta_{114-110}\right)$ for $\mathrm{Cd}$ complexes from 0 to $100^{\circ} \mathrm{C}$.

\begin{tabular}{ccccccc}
\hline $\mathrm{T}\left({ }^{\circ} \mathrm{C}\right)$ & 0 & 10 & 25 & 40 & 50 & 100 \\
\hline $\mathrm{Cd}\left(\mathrm{H}_{2} \mathrm{O}\right)_{4}{ }^{2+}$ & 2.537 & 2.370 & $2.148 \pm 0.0046$ & 1.956 & 1.841 & 1.395 \\
$\mathrm{Cd}\left(\mathrm{H}_{2} \mathrm{O}\right)_{6}{ }^{2+}$ & 2.711 & 2.530 & $2.292 \pm 0.0039$ & 2.085 & 1.962 & 1.484 \\
$\mathrm{Cd}(\mathrm{cit})_{2}{ }^{4-}$ & 2.715 & 2.533 & $2.292 \pm 0.0029$ & 2.084 & 1.961 & 1.481 \\
$\mathrm{Cd}(\mathrm{Hcit})\left(\mathrm{H}_{2} \mathrm{cit}\right)^{-}$ & 2.961 & 2.765 & $2.505 \pm 0.0039$ & 2.280 & 2.147 & 1.626 \\
$\mathrm{CdH}(\mathrm{cit})\left(\mathrm{H}_{2} \mathrm{O}\right)_{4}$ & 2.871 & 2.681 & $2.429 \pm 0.0038$ & 2.211 & 2.081 & 1.576 \\
$\mathrm{Cd}(\mathrm{cit})\left(\mathrm{H}_{2} \mathrm{O}\right)_{3}{ }^{-}$ & 2.943 & 2.749 & $2.491 \pm 0.0046$ & 2.268 & 2.135 & 1.618 \\
$\mathrm{CdEDTA}$ & 2.811 & 2.621 & $2.371 \pm 0.0026$ & 2.155 & 2.026 & 1.529 \\
$\mathrm{Cd}(\mathrm{his})_{2} \mathrm{H}_{2} \mathrm{O}$ & 2.777 & 2.590 & $2.344 \pm 0.0027$ & 2.131 & 2.005 & 1.514 \\
$\mathrm{Cd}(\mathrm{DMPS})_{2}{ }^{4-}$ & 1.575 & 1.467 & $1.325 \pm 0.0011$ & 1.203 & 1.130 & 0.850 \\
$\mathrm{Cd}(\mathrm{DMPS})\left(\mathrm{H}_{2} \mathrm{O}\right)_{2}{ }^{-}$ & 2.086 & 1.946 & $1.761 \pm 0.0022$ & 1.601 & 1.506 & 1.138 \\
$\mathrm{Cd}(\mathrm{cys})\left(\mathrm{H}_{2} \mathrm{O}\right)_{3}{ }^{2+}$ & 2.233 & 2.084 & $1.887 \pm 0.0026$ & 1.716 & 1.614 & 1.220 \\
$\mathrm{Cd}(\mathrm{GS})_{2}\left(\mathrm{H}_{2} \mathrm{O}\right)_{2}{ }^{2-}$ & 2.130 & 1.987 & $1.799 \pm 0.0025$ & 1.635 & 1.539 & 1.162 \\
\hline
\end{tabular}




\section{Click here to access/download Supplementary file Supplementary material.docx}




\section{Highlights:}

The isotope fractionation order of selected Cd organic complexes was given.

Compared to hydrated $\mathrm{Cd}$, organic complexes with $\mathrm{O}$ and $\mathrm{N}$ donors enrich heavier $\mathrm{Cd}$ isotopes, complexes with $\mathrm{S}$ donors enrich lighter isotopes.

Organic ligands with S donors: chelating ligands were enriched in light isotope compared to non-chelating ligands.

$\mathrm{Cd}\left(\mathrm{H}_{2} \mathrm{O}\right)_{6}{ }^{2+}$ is enriched in heavy isotope compared to $\mathrm{Cd}\left(\mathrm{H}_{2} \mathrm{O}\right)_{4}{ }^{2+}$. 